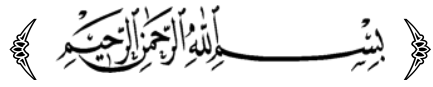

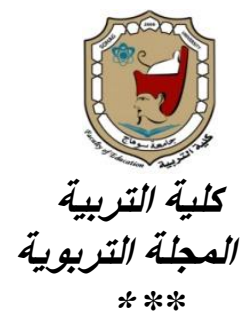

برناهمج هقتزح قائم

على همايير العلوم للبيل القادم (NGSS)

لتدريب هماتهي العلوم بالمرحلة الإعدادية على الستفدام همارسات العلوم والهندسة (SEPs) أثناء تدريس العلوم

\title{
إعداد
}

أ.م.د. محرم بهمبى محمد محمد عثبذي

أستاذ المناهج وطرق تدريس العلوم المساعد

كلية التربية - جامعة عين شمس

أستاذ المناهج وطرق ثدريس العلوم المشارت

الكلية الجامعية بالقنفذة - جامعة أم القرى

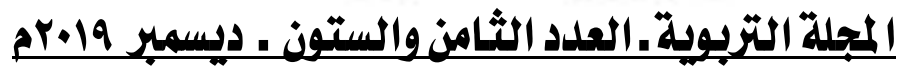

Print:(ISSN 1687-2649) Online:(ISSN 2536-9091) 


\section{ملخص البجثث:}

هدف البحث الحالي إلى بناء برنامج تدريبي مقترح لمعلمي العلوم بمصر قائم على معايير العلوم للجيل القادم (NGSS) لتمية قدرتهم على استخدام ممارسات العلوم واللهندة أثناء تلريس العلوم. ولتحقيق هذا الهذف قام الباحث بتحديد مدى استخدام معلمو (SEPs) العلوم بالمرحلة الإعدادية لممارسات العلوم والهندسة بمعايير العلوم للجيل القادم بداخل الفصول ، وذلك من خلال استخدام التقرير الذاتي لهم، حيث قام الباحث بإعداد استبيان تكون من ( ^ ) بنود تمثل ممارسات العلوم والهندسة وقام بتطبيقه على مجموعة من معلمي العلوم بمحافظة القاهرة الكبرى تكونت من ( 0 P ) معلماً ومعلمة. كما قام الباحث بإعداد استبيان أخر تكون من ( 19 ) بنداً لبيان مدى تطبيق الطلاب لممارسات العلوم والهندسة أثناء حصص العلوم. قام الباحث بتحديد الاحتياجات التدريبية لمعلمي العلوم في ضوء ممارسات العلوم والهندسة من خلال إعداد استبيان مخصص لذلك تكون من ( 1 ) ) أبعاد أساسية تمثل ممارسات العلوم والهندسة، كما أشتمل على ( 1 ( ) بند فرعي، وتم تطبيقه على معلمى العلوم. وقد أظهرت نتائج البحث أن معلمو العلوم يستخدمون ممارسات العلوم والهندسة بلرجة " متوسطة " ، كما أن استخدامهم لبعض الممارسات كان بدرجة " منخفضة " وذلك في ضوء التقرير الذاتي لهم. كما أظهرت نتائج البحث أن تطبيق الطلاب لممارسات العلوم والهندسة كان بلرجة " منخفضة " بشكل عام. أوضحت النتائج أن هناك حاجة " كبيرة " لتدريب معلمي العلوم على استخدام ممارسات العلوم والهندسة. استخدم الباحث ما تم التوصل إليه من نتائج في بناء البرنامج التريبي المقترح الأي تكون من ( ه ) أيام تدريبية

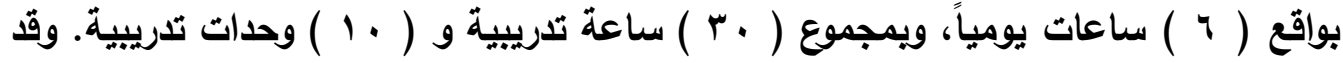
قدم البحث مجموعة من التوصيات والمقترحات التي يمكن أن تسهم في تطوير التربية العلمية بشكل عام، وفي إعداد معلم العلوم وتدريبه بشكل خاص.

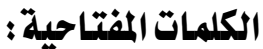

معايير العلوم للجيل القادم (NGSS) - ممارسات العلوم والهندسة (SEPs) - تدريب المعلم - إعداد المعلم - البرامج التدريبية - التربية العلمية. 


\section{Abstract:}

This research aims at introducing a suggested training program for science teachers in Egypt based on Next Generation Science Standards [NGSS] for developing Science teachers' ability in using Science and Engineering Practices [SEPs] in science teaching. To achieve this goal the researcher measured the degree of using [SEPs] among science teachers in preparatory school, through their self - report. The researcher prepared a questionnaire consisted of (8) items that express the [SEPs] and applied it to a group of science teachers consisted of (25) teachers. The researcher also prepared another questionnaire consisted of (16) items to measure the degree of the applications of the [SEPs] in science classrooms that made by students. The researcher defined the need of science teachers for training in light of [SEPs] through preparing a questionnaire for this purpose which consisted of (8) basic domains that express [SEPs], and with (86) items, and was applied to science teachers' group. Results showed that the degree of science teachers' usage of the [SEPs] is "Moderate ", and some practices was with a "Low" usage degree from their self - report. Result also revealed that students' applications of [SEPs] is "Low" in general. Results also revealed the "High" degree of science teachers' training need of using [SEPs]. The researcher used the results in constructing the suggested training program, which consisted of (5) training days, with (6) hours daily and total of (30) training hours, and (10) training units. The research introduced some recommendations and suggestions which may contribute to developing science education in general and science teacher preparation and training.

- Keywords: Next Generation Science Standards [NGSS] - Science and Engineering Practices [SEPs] - Teacher training - Science Education training programs. 


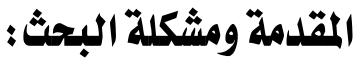

يعتبر العلم ويالتالي التربية العلمية محور حياة جميع المواطنين. فاليوم أصبح

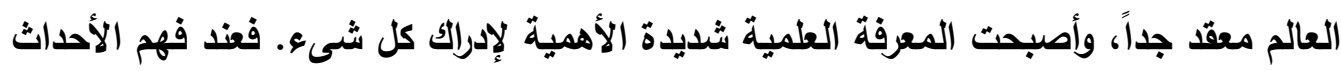
الجارية، واختيار واستخام التكنولوجيا، أو اتخاذ القرارات المستتيرة فيما يرتبط بالرعاية الإداية

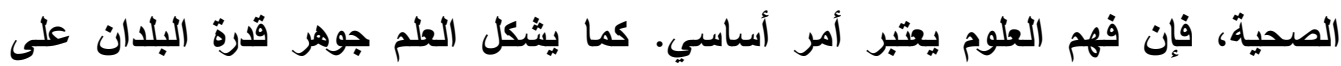
الاستمرار فى ابتكار وقيادة وظائف المستقبل. ومن ثم فجميع الطلاب على اختلاف تخصصاتهم يجب أن يكون لايهم قدر من التربية العلمية القوية بمرحلة التعليم من الروضة إلى نهاية المرحلة الثانوية.

يتميز العصر الحالي بنمو المعرفة التقتية التى تؤثر على حياة أفراد المجتمع. ولكي يثارك المواطن فى هذا العصر، فإنه يحتاج إلى أن يكون متتوراً علمياً من خلال التربية (Almomani, 2016) . ويناء عليه فإنه على متخذي القرار التريوي مسؤولية

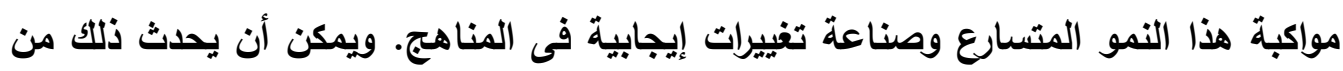

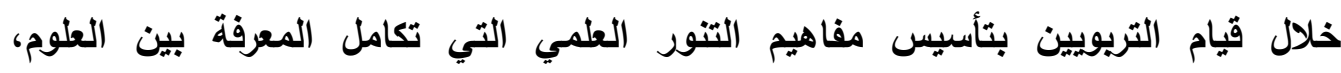
والرياضيات، والتكنولوجيا (Alweher, 2016; Gassom, 2013). ويالرغم من هذه الأهمية للعلوم والتربية العلمية للفرد والمجتمع، فإنتا نجد أن هناك

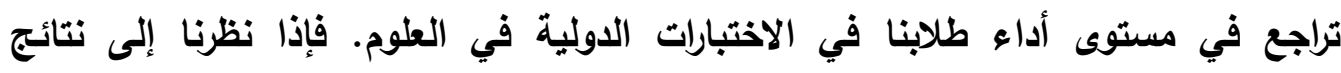

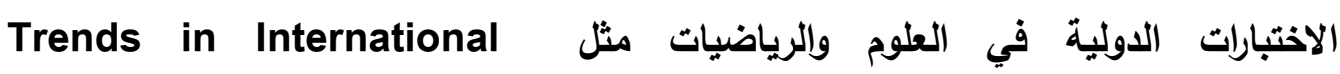
Mathematics and Science Study [TIMSS]

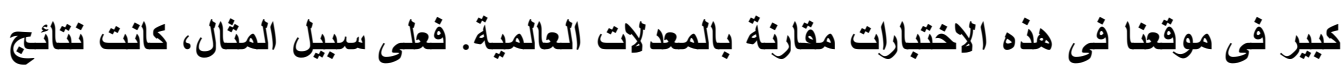

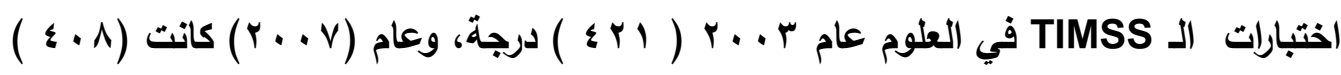

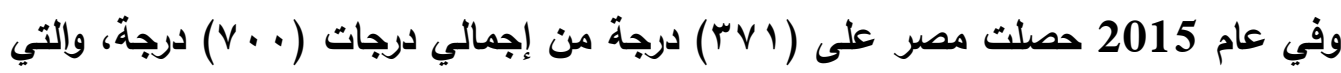

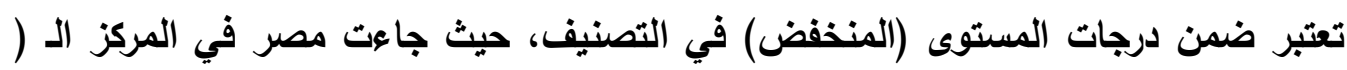

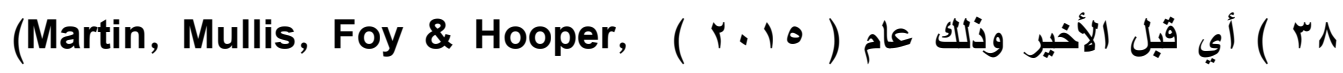
(2016) وياتتالي تعتبر هذه النتائج مقلقة للغاية بالنسبة للتربويين فى مصر ، ويجب أن أن يتم التعامل معها حتى يتم اتخاذ اللازم لتطوير تدريس العلوم والتربية العلمية لجميع المواطنين. 
ويوضح شكل (1) متوسط أداء طلاب الصف الثامن (الثاني الإعدادي) فى اختبار ف TIMSS فى درجات الاختبار • وفي ضوء هذا الانحدار لاى الطلاب فى الأداء على الاختبارات الدولية مثل TIMSS، فإن الحاجة لتوليد معايير جليدة أو أفضل للتربية العلمية أصبحت واضحة لاى الكثير من التربويين.

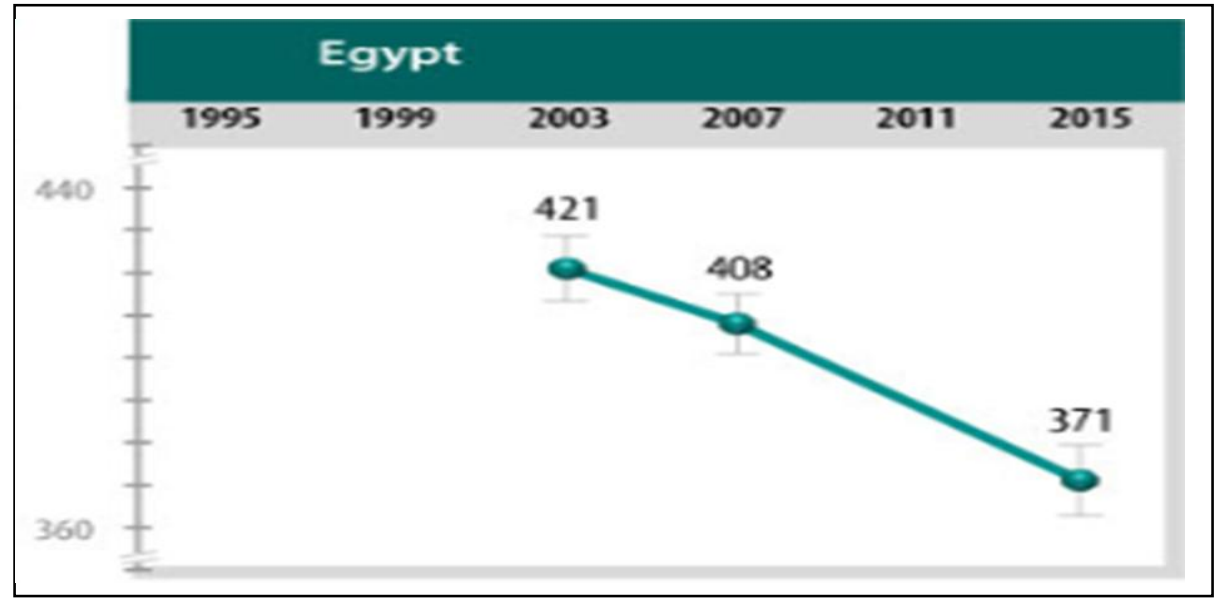

شكل ( 1 ) متوسط أداء طلاب الصف الثامن في جمهورية مصر العربية في العلوم في اختبارات

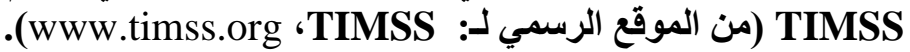

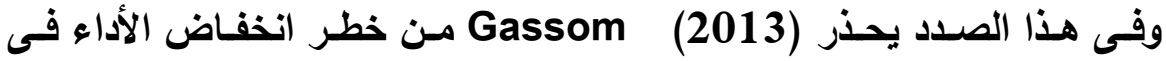
اختبارات العلوم الدولية، ويرى أن تدريس العلوم فى العالم العربي يحتاج إلى قفزة إصلاحية كبير لتحسين جودتـه بشكل سريع. وتتفق (2018) Saleh و (2016) Alweher ميع (2016) Gassom (2013)

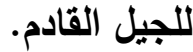

Next Generation Science وتعتبر معايير العلوم للجيل القـادم هـ Standards [NGSS] الأمريكيـة. وتعتبر الثكل الأحلدث لجهود وتطوير معايير التربيـة العلميـة التي استمر قرابـة

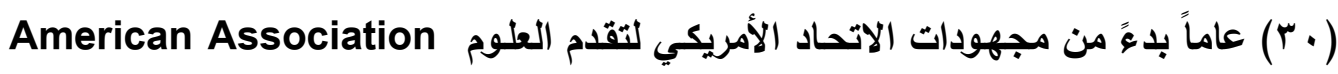
for the Advancement of Science [AAAS] في عـام ه191 وذلـك لمسـاعدة كل الأمسريكيين لكي يصبحوا متــورين علميـاً في العلـوم 


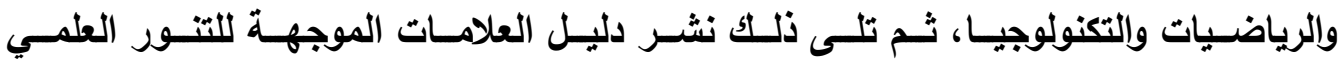
Benchmarks for Science Literacy ترجم الغايـات Goals المدرجـة في مشروع "العلم لكل الأمريكيين" إلى أهداف تعليميـة أو الو علامات موجهة للمراحل (K-12) والعديد من وثائق المعايير القومية للولايات المتحدة اليوم

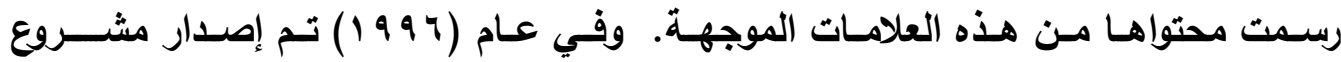

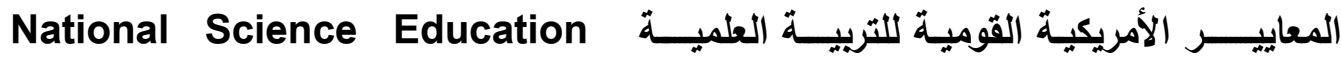
(National Reseach Council, 1996) Standards[NSES]

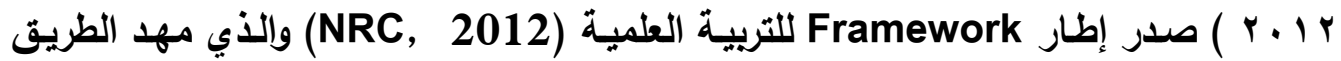

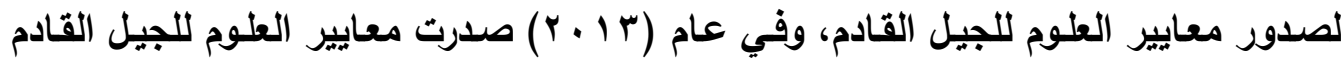
[NGSS] تم بنـاء معـايير العلـوم للجيـل القـادم بالولايات المتحدة الأمريكية والتي تعتبر معايير جديدة للعلوم وثريـة فى المحتـوى العلمـي والممارسـة وتنظيمها بشكل متسـق عبر النظم العلميـة وإلتخصصـات (Achieve, المختلفة والمراحل المختلفة لتزويد كل الطلاب بتربية علمية ذات مرجعية دولية

وتختلف معايير (NGSS) عن معايير (NSES) بشكل جذري، ويالتالي يحتاج المعلم إلـى فهم الأهداف الخاصـة بمعـايير (NGSS) بشـكل عميق لكي ينفذها ويستطيع استخدامها أثناء تدريسـ (Pruitt, 2014) . وتثكل معايير(NGS) تحدياً كبيراً لمعلمي

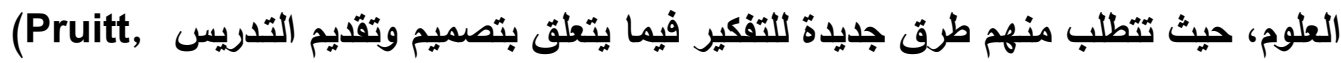

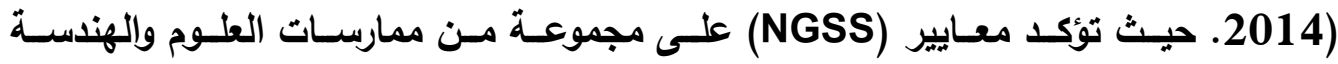
Science and Engineering Practices [SEPs] التركيز على معرفـة المحتـوى واللذى تـم التركيز عليـه فـى المعـايير السـابقة مثل معسايير

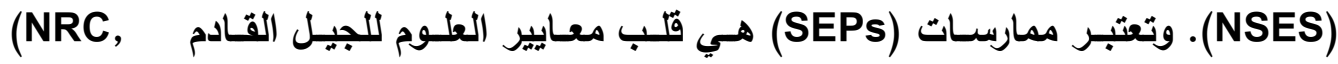
(2012، كما إنها نتاج العمل لسنوات عديدة للبحث فى التربية العلمية فيما يرتبط بالاندماج ذو المعنى والمنتج فى فصول العلوم عindschitl,Thompson, Braaten, \& Stroupe , 2012) 
برنامج مقترح قائم على معايير العلوم للجيل القادم (NGSS) لتدريب معلمي العلوم بالمرحلة الإعدادية ...

ويعد التأكيد على ممارسـات العلوم والهندسـة (SEPs) اهتمـام جديد، كمـا أنسه

يتضمن قضايا مهمة، فعلى سبيل المثال مساعدة المربيين على الفهم العميق للروئية وإلتظيم والأهداف لمعايير (NGSS) متضمنة ممارسـات العلوم والهندسة يمثل خطوة أولى وحتمية لتطوير مواد المناهج عالية الجودة (Pruitt, 2014) ، ولتحقيق النجاح فى هذا يجب تقديم

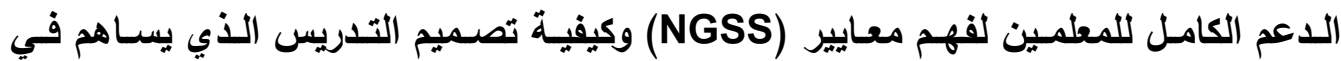
تحقيق هذه المعايير.

وتتبع أهمية التأكيا على ممارسات العلوم واللهندة أثناء تدريس العلوم فيما يأتي: 1. إن الاندماج في ممارسات العلوم يساعد الطلاب على فهم كيفية تطور المعرفة العلميـة، كما أن الاندماج في ممارسات الهندسة يساعد الطلاب على فهم عمل المهندسين وأيضاً الروابط بين العلوم والهندسة (NRC, 2012) r. إن الاشـتراكك في هذه الممارسـات يسـاعد الطـلاب أيضـاً على فهم المفـاهيم المتقاطعـة Crosscutting Concepts والهندسة، كما أنها تجعل معرفة الطلاب ذات معنى وتوظيفها بشكل أعمق عند روئتهم للإلم. r. إن ممارسـة العلوم والهندسـة بشكل فعلى يمكن أن تثير حب الاستطلاع للدى الطلاب، وتستحوذ على اهتمـامهم وميولهم، وتحفز تعلمهم المستمر ، وفي النهايـة إدراكهم بأن عمل العلماء والمهندسين هو عمل ابتكاري وإبداعي.

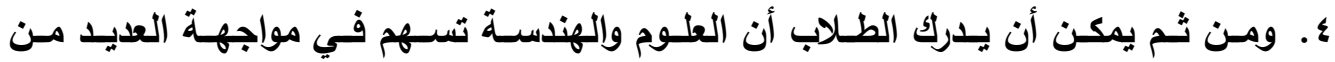

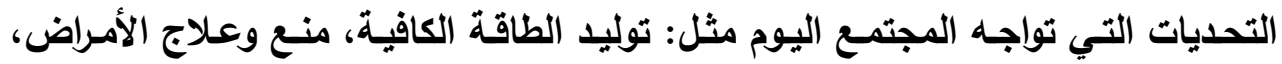
الحفاظ على إمدادات المياه العذبة والغذاء، ومواجهة التغيرات المناخية. ه. التقييم للعلوم في المستقبل: فى المستقبل، لن يتم تقييم العلوم لفهم الطلاب للمفاهيم الرئيسية المحورية بشكل منفصل عن قدرتهم على استخدام ممارسـات العلوم واللهندسة. حيث سيتم تقييم هذين البعدين معاً، بحيث يتم تحديد مدى معرفة الطلاب بالمفـاهيم

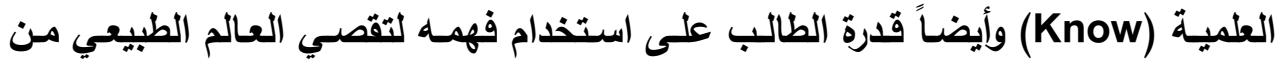
خلال ممارسات العلوم واللهنسة متضمنة الفحص العلمي، والقدرة على حل مشكلات ذات المغنى من خلال ممارسات التصميم الهندسي (NRC, 2012) . 
برنامج مقترح قائم على معايير العلوم للجيل القادم (NGSS) لتدريب معلمي العلوم بالمرحلة الإعدادية.

ويمكن تحديد أهمية الجمع بين ممارسات العلوم والهندسة والأفكار الرئيسية التخصصية

كما يحددها إطار التربية العلمية في أن الطلاب لا يستطيعون فهم الأفكار العلمية والهندسية بشكل كامل دون المشاركة فى ممارسات الاستقصاء والحوار التى يتم من خلالها تطوير هذه الأفكار وصقلها، وفى نفس الوقت لا يمكنهم تعلم أو إظهار الكفاءة إلا في سياق محتوى علمـي معين (NRC, 2012). 2012) ولطبيعـة بعض الممارسـات لا يمكن اسـتخدامها عـادة

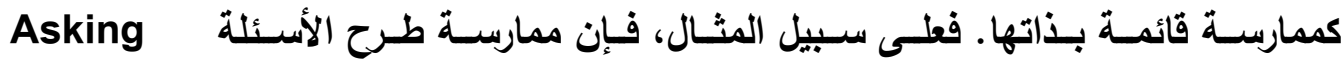
غالباً ما تؤدي إلى تقصي وفحص والذي ينتج بيانات Data Questions تستخدم كدليل Evidence لتطوير الحجج العلمية Arguments. وتعمل معايير (NGS) على دمج الممارسات داخل توقعات للأداء [Performance Expectations [PEs، ومـع

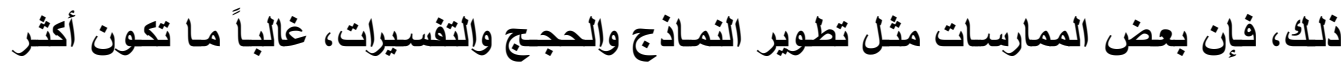
بروزاً فى جميع المعايير .

ومــع التبــي القـومي لمعـايير العلـوم للجيـل القـادم بالولايـات المتــــة الأمريكيـة أصبح الممارسون والباحثون مهتمين بشكل متزايد بالوصول إلى طرق تلدعم المعلمين فى تصميم التدريس بالفصل الدراسي لمقابلة أهداف معايير (PGS) (Pelligrino, 2013). (إن معرفة كيفية تدريس العلوم للطلاب على أفضل وجـه أمر بالغ الأهمية، بسبب التأثير الحاسم (Bennett \& لمعلمي العلوم على طلابهم في روئة العلوم، وآرائهم فيها والمهن التى تثملهات (Yoon, suh, \& Park , 2014 وإتجاهات طلابهم نحوها (Yoorth, 2009). ونظراً لهذه المتطلبات الجديدة والمختلفة بشكل كبيز، فإنها من الضروري إجراء بحث لتقصي مدى

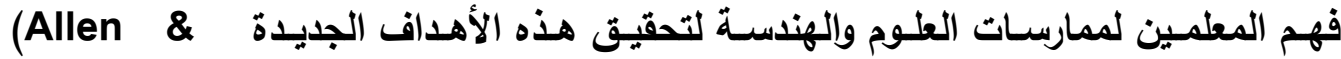
S. كما أوضحت نتائج اختبارات العلوم الدولية احتياج كبير للمعلمين ليكونـوا أفضل فى نقل المعرفة العلميـة لطلابهم Malkawy ) Rababah, 2018) العلـوم والهندسـة مـن أجل تطوير نمـاذج ومصـادر تعلـم المعـم أثنـاء بـرامـج النمـو المهنـي .(Kawasaki, 2015) وفي هذا الصدد أجرت (2018) Saleh دراسـة لتقييم تنفيذ معايير NGSS من أجل تحديد فعاليتها في إحدى مـارس المنـاهج الأمريكيـة الخاصـة في دبـي، بالإمـارات العربيـة 
برنامج مقترح قائم على معايير العلوم للجيل القادم (NGSS) لتدريب معلمي العلوم بالمرحلة الإعدادية

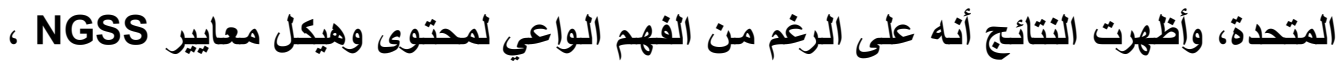

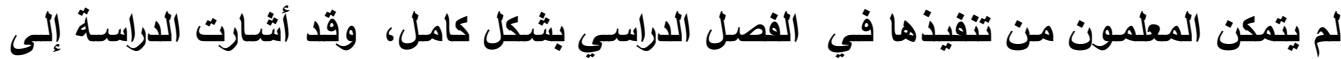
وجود فجوات بين معايير NGSS المتصورة والمنفذة في الفصول الدراسية، وأثشارت إلى أن الثفرات في تنفيذ المناهج الدراسية يرجع إلى مجموعة متنوعة من التحديات بما في ذلك ندرة

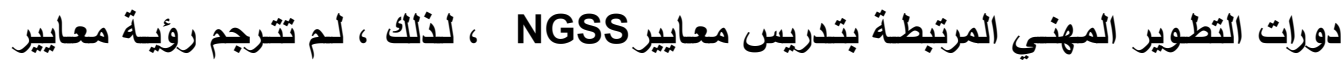
NGSS بشكل كامل إلى ممارسـات بالفصل الدراسي ممـا أدى إلى التنفيذ غير الكامل وعدم الفعالية في إعداد الطلاب على النحو المنشود (Saleh, 2018).

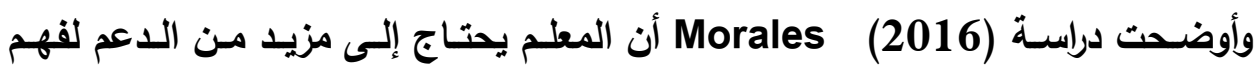

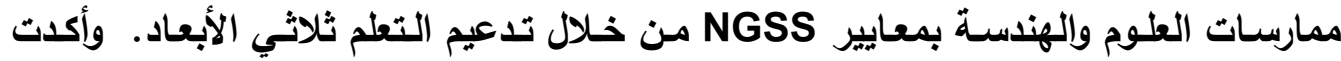
دراسة (2014) على أهمية إشراك الطلاب في التحقيقات وتسهيل الحوار بالفصل الدراسـي وتطوير لغة مشتركة لتدريس العلوم مـع التأكيد على التقويم المستمر كممارسـات أساسية للعلوم والهنذسـة. ويالنظر إلى أرض الواقع نجد على العكس من ذلك، حيث يسود

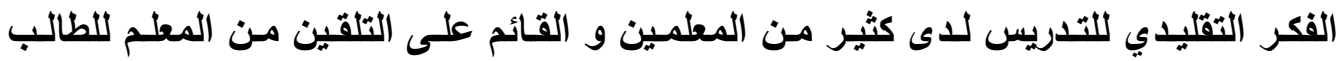

.(Taylor \& Booth, 2015) و يرى (2015) أن فهم معلمي العلوم لممارسـات العلوم واللهندسـة (Hattie, يوأثر على التصميم التدريسي لهم، ويالتالي يساعدهم على تعديل وتتقيح دروسهم: (2012. ويمكن القول إنهله من خـلال مراجعة الأدبيات فإن الأدلة التجريبية تؤكد التأثيرات الإيجابيـة الناتجـة عن استخدام ممارسـات العلوم واللهندسة [SEPs] أثنـاء تـريس العلوم ـ كما أشارت الدراسات السابقة إلى أنـه (Kloser, 2014; Duschi \& Bybee, 2014) يقع على عاتق المعلمين مسؤولية كبيرة لفهم الروئة الجديدة لمعايير (NGSS) وتطبيقها بشكل فعال. كما أوضـت الأدبيات أيضـاً أن المعلمين يكونون أفضل فى تطبيق ممارسـات (Duschi \& Bybee, بعد حضور جلسـات للتدريب عليها 2014, Lederman \& Lederman , 2013; NSTA , 2013) البرامج التدريبيـة فرصـة لزيـادة فهم المعلمسين لأهداف معـايير (Allen \& $\quad$ (NGSS) .Penuel, 2014; Craw Fored et al., 2014) 
والبحث الحالي يعتبر استجابة إلى الحاجة إلى نماذج ومصادر للدعم المعلمين أثناء الانتقال إلى معايير (NGSS) مـن خـلال تـدعيم استخدام ممارسـات العلوم واللهندسـة أثناء تـدريس

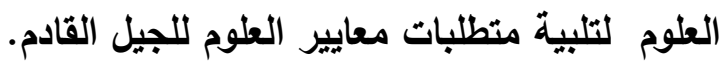
وفي هذا الإطار أجرى الباحث دراسـة استطلاعية هدفت إلى تعرف مدى فهم مجموعة من معلمي العلوم بالمرحلة الإعدادية لممارسات العلوم والهندسة بمعايير العلوم للجيل القادم. حيث تـم تطبيق اختبـار اسـطنلاعي' يتضـمن مجموعـة مـن الأسـئلة عن ممارسـات العلوم

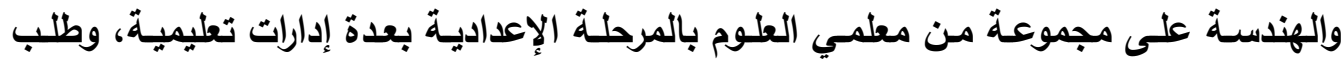
منهم وصف كل ممارسـة من الممارسات في ضوع فهمهم وتصورهم واستخدامهم لها أثناء تدريس العلوم، وقد تبين من تطبيق الاختبار قصور فهم واستخدام المعلمين لهذه الممارسات أثناء تدريس العلوم. ومن هذا المنطلق، فإنه يجب تعديد إلى أي مدى يستخدم معلمو العلوم لممارسات العلوم والثهنسة (SEPs) أثناء تلدريس العلوم حيث لا توجد بيانات كمية محددة حالياً بهذا الثأن، وأيضاً مدى تطبيق طلابهم لها أثناء حصص العلوم وذلك كخطوة أولية لبناء برنامج لتدريبهم على استخدام هذه الممارسات أثثاء تدريس العلوم. ويمراجعة الأدبيات، وجد أنه لا توجد دراسـات سـابقة - على حد علم الباحث - أظهرت مدى استخدام معلمو العلوم فى مصر بالمرحلة الإعدادية لممارسـات (SEPs) أثناء تدريس العلـوم. حيـث إنـه فـى ظل غيـاب الفهـم لممارسـات العــوم والهندسـة (SEPs) بمعـايير سوف يواجـه المعلم تحدياً كبيراً لتوجيـه تدريسـه لهذه الممارسـات. حيث يواجـه

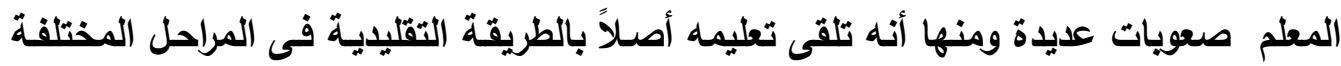

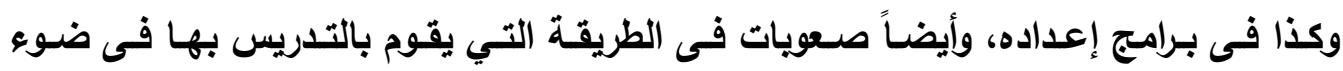
المعايير السـابقة. ومـن هذا المنطلق فإن البحث مطلـوب لتطوير نمـاذج ومصـادر لتدعيم المعلمين فى تعلم كيفية ابتكار وتبني الفرص التعليمية المرتبطة بممارسـات العلوم واللهندسة (SEPs) للاراسات المستقبلية فيما يتعلق بهذا المسار وذلك لاستكشاف مدى استخدام هذه الممارسات أثناء تدريس العلوم بحيث يزداد هذا الاستخدام، حيث إنه لكي يتم زيادة استخدام ممارسات

'ملحق ( 1 ): اختبار استطلاعي في ممارسات العوم و الهندسة SEPs بمعايير العلوم للجيل القادم NGSS 
برنامج مقترح قائم على معايير العلوم للجيل القادم (NGSS) لتدريب معلمي العلوم بالمرحلة الإعدادية

يجب الفهم للاستخدام الحالي لها. وفي ضوء هذا الفهم يمكن بناء برنامج تدريبي (SEPs) لتدعيم المعلمين فى جهودهم لاستخدام ممارسات العلوم والهندسة أثناء تدريسهم. من خلال العرض السابق يمكن تحديد النقاط التالية: 1. ضعف مستوى المنافسة العالمية لطلاب المرحلة الإعدادية في مصر في تحصيل العلوم.

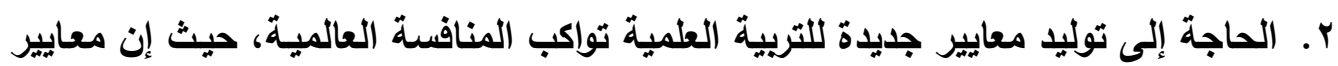
العلوم القائمة لم تعد كافية للتعامل مع واقع تدريس العلوم على مستوى العالم. r. لا يوجد تحديد علمي لدرجة استخدام معلمي العلوم لممارسـات العلوم والهندسة بمعايير العلوم للجيل القادم ولا لارجة تطبيق طلابهم لها أثناء حصص العلوم.

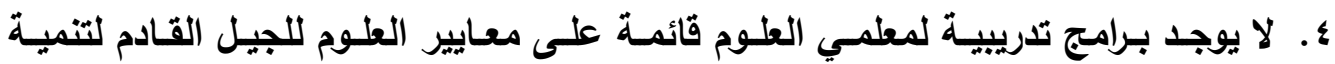
قدرتهم على استخدام ممارسات العلوم والهندسة أثناء تلريس العلوم.

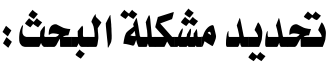

تحـددت مشـكلة البحـث الحسالي في: " قصـور اسـتخدام معلمسي العلـوم لممارســات العلـوم والهندسـة (SEPs) بمعـايير العلـوم للجيـل القـادم (NGSS) أثنــاء تـــريس العلـوم لطـلاب

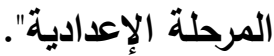

وللتصدى لهذه المشكلة حاول البحث الإجابة عن السؤال الرئيس التالي: كيف يمكن إعداد برنامج مقترح قائم على معايير العلوم للجيل القادم (NGSS) لتدريب معلمي العلوم بالمرحلة الإعدادية على استخدام ممارسات العلوم والهندسة (SEPs) أثناء

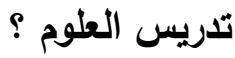
وتفرع عن هذا السؤال الرئيس الأسئلة الفرعية التالية: ا. ما مدى استخدام معلمو العلوم بالمرحلة الإعدادية لممارسات العلوم والهندسة (SEPs) بمعايير (NGSS) أثناء تدريس العلوم ؟ r. ما مدى تطبيق طلاب المرحلة الإعدادية لممارسات العلوم والهندسة (SEPs) بمعايير ( أثناء حصص العلوم (NGSS) r. مـا الاحتياجـات التدريبية لمعلمي العلوم بالمرحلـة الإعداديـة في ضوع ممارسـات العلوم

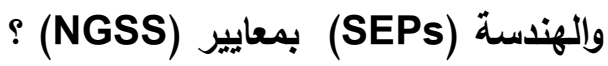


برنامج مقترح قائم على معايير العلوم للجيل القادم (NGSS) لتدريب معلمي العلوم بالمرحلة الإعدادية

؛. ـــا التصـور المقترح للبرنـامج لتدريب معلمي العلوم بالمرحلـة الإعداديـة على استخدام

ممارسات العلوم والهندسة (SEPs) بمعايير (NGSS) أثناء تدريس العلوم ؟

• حلدود البحث: اقتصرت حدود هذا البحث على:

ا. مجموعة من معلمي العلوم بمحافظة القاهرة الكبرى بالمرحلة الإعداديـة " بأربعة إدارات تعليمية فقط " هي: الزيتون، مدينة نصر، الخانكة، العبور.

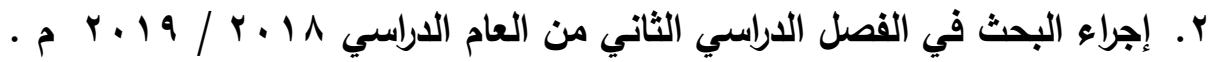

r. ممارسات العلوم والهندسة (SEPs) بمعايير العلوم للجيل القادم (NGSS) والتتي صدرت

عام ب ا ـ ب بالولايات المتحدة الأمريكية.

ع. جمع البيانات من خلال التقرير الذاتي Self - Report باستخدام الاستبيانات المعدة بطريقة مقياس ليكرت Likert Scale لمعلمي العلوم بالمرحلة الإعدادية. ه. * نتائج البحث محددة بمكان وزمان إجراؤه . تحليد مصطلحات البحث:

( 1 ) معايير العلوم للجيل القـادم NGSS : ترجع معايير العلوم للجيل القادم (NGS) إلى إطار التربية العلمية والهنلسية (K-12) والذي تم تطويره بواسطة المركز القومي للبحث (NRC)، والذي يحتوي على ثلاثـة أبعاد للتعلم هـي: المفـاهيم (المتقاطعـة) الثــاملة Concepts ، Crosscutting C والأفكـار التخصصـية الأساســية Science and Disciplinary Core Ideas .(NRC, 2012; NGSS, 2013) Engineering Practices (SEPs) ويمكن تعريف معايير العلوم للجيل القادم (NGSS) على أنها توقعات الأداء Performance Expectations (PEs) به لإظهار الكفاءة فى العلوم، حيث تقترن ممارسات العلوم واللهندة (SEPs) مع المفاهيم المتقاطعة Concepts(CCs) Disciplinary Ideas(DCIs) لتقديم معلومات للمعلمين ومطوري المنهج والتقييم بما يتجاوز معيار الخط (NGSS) الواحد التقليدي (NGSS, 2013). 
: Science and Engineering Practices[SEPs] ممارسات العلوم والهندسة ( ) عبارة عن الممارسـات الأساسية التى يوظفها العلمـاء عند قيامهم بالفحص العلمي ويناء النماذج والنظريات عن العالم، وأيضاً مجموعة من ممارسـات الهندسة التى يستخدمها لتهاء المهندسون عند تصميمهم وينائهم للنظم، وتتضمن ( A ) ممارسات أساسية. وتتمثل ممارسات العلوم واللهندسة (SEPs) في : [1] طرح الأسئلة ( في العلوم ) وتحديد المشكلات ( في الهندسة ).

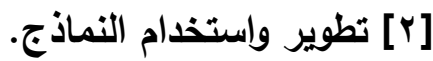
[r] [بطيط وتنفيذ الإستقصاءات (التحقيقات). [ [ ] تحليل وتفسير (ترجمة) البيانات.

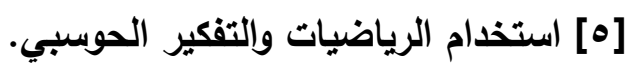
[7] بناء التفسيرات وتصميم الحلول. ] الاندماج فى الحجة العلمية باستخدام الدليل ( المحاجة وإقامة الاليل ). [^] الحصول على المعلومات وتقويمها وتواصلها ( التواصل بواسطتها ). (NGSS, 2016; NGSS, 2013; NRC, 2012)

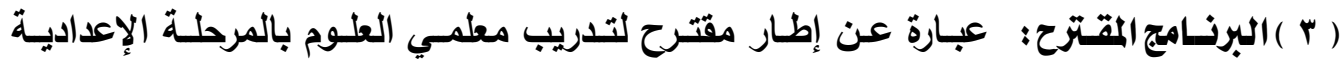
بجمهوريـة مصر العربيـة يهدف إلى تدريب معلمي العلوم على استخدام ممارسـات العلوم

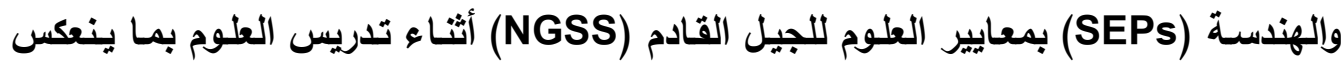
على مساعدة طلابهم على تطبيقها أثناء حصص العلوم. • أهداف البحث : هدف البحث الحالى إلى: 1. تحديد مدى استخدام معلمو العلوم بالمرحلة الإعدادية لممارسات العلوم والهندسة

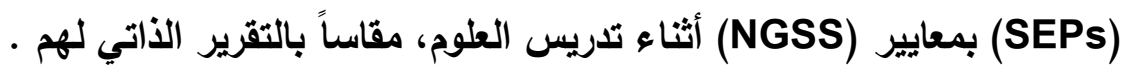
r. تحديد مدى تطبيق طلاب المرحلة الإعدادية لممارسات العلوم والهندسة (SEPs) بمعايير (NGS) أثناء حصص العلوم، في ضوء التقرير الذاتي لمعلميهم . r. تحديد الاحتياجات التدريبية لمعلمي العلوم بالمرحلة الإعدادية في ضوء ممارسات العلوم والهندسة (SEPs) بمعايير (NGS) 
برنامج مقترح قائم على معايير العلوم للجيل القادم (NGSS) لتدريب معلمي العلوم بالمرحلة الإعدادية

؛. إعداد برنامج مقترح قائم على معايير العلوم للجيل القادم (NGSS) لتدريب معلمي العلوم بالمرحلة الإعدادية على استخدام ممارسات العلوم والهندسة (SEPs) أثناء تدريس العلوم.

\section{أهمية البحث: تتبع أهمية البحث لما يمكن أن يقدمه لكل من:}

1. كليات التربيـة: وذلك من خـلال التأكيا على ممارسـات العلوم والهندسـة بمعايير العلوم للجيل القادم أثثاء إعداد معلمي العلوم وذلك من خـلال المقررات الأكاديمية أو مقررات طرق التدريس بحيث يصبح معلم المستقبل على درايـة كامله بهذه الممارسـات وكيفية استخدامها ومساعدة طلابه على تطبيقها أثناء حصص العلوم. r. وزارة التربيـة والتعليم: تنبـع أهمية هذا البحث نظراً لأن الدول المتقدمـة بـأت في تبنـي معـيير (NGSS) الجديـدة. ويمكن أن تفيــ النتـائج فى تصـميم بـرامج النمـو المهنـي Professional Development

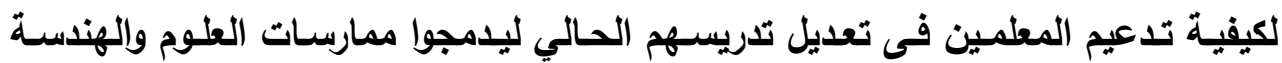
الموجودة في معايير (NGSS) من خـلال استخدام البرنـامج التدريبي المقترح لتحقيق ذلك.

r. مطوري المنـاهج: وذلك من خـلال التأكيد على بنـاء منـاهج العلوم الجديدة وفقاً لمعايير

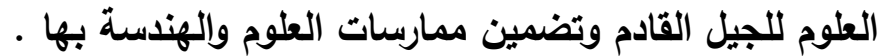

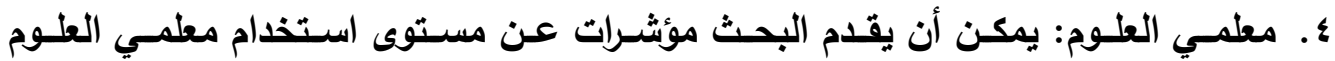

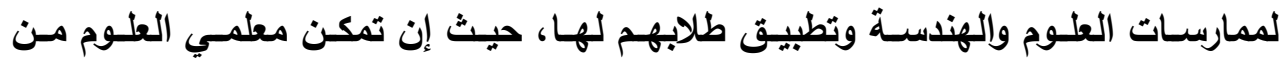
استخدام ممارسات العلوم والهندسة أمر بالغ الأهمية في مساعدة طلابهم على تطبيقها، ومن ثم مساعدتهم على المنافسة العالمية في اختبارات العلوم الدولية. ه. الطلاب: من خلال مساعدتهم على تطبيق ممارسـات العلوم وإلهندسة أثناء دراسـة العلوم والذي ينعكس على مستوى تحصيلهم للعلوم ووصولهم للمستويات العالمية .

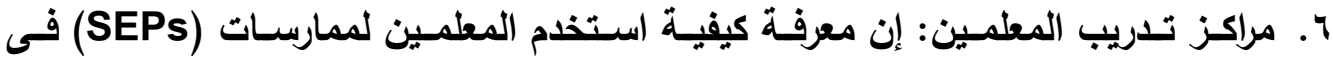
فصولهم الدراسية يمكن أن يساعد متخذي القرار بالمدارس والمديرين ليصبحوا أكثر درايـة

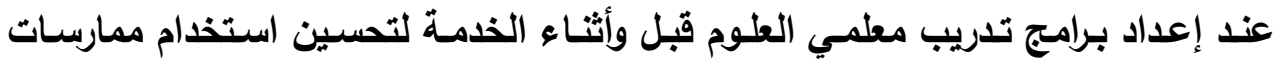




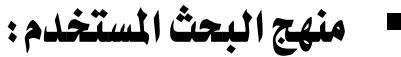

استخدم الباحث المـنهج الوصفي وذلك لتصديد مـى استخدام ممارسـات العلـوم

والهندسة (SEPs) بمعايير (NGS) بين معلمي العلوم وتطبيقها من قبل الطلاب أثناء

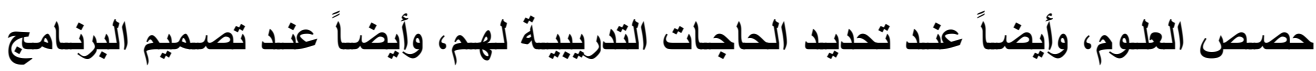
التدريبي المقترح لتنميـة قدرة معلمي العلوم على استخدام هذه الممارسـات أثناء تلدريس العلوم.

\section{الإطار النظري للبحث}

ممارسات العلوم والهندسة (SEPs) بمعايير العلوم للجيل القادم(NGSS) وتدريب معلم العلوم على استخدامها أثناء تلدريس العلوم" يتناول الإطار النظري للبحث ممارسات العلوم واللهندسة ومعايير العلوم للجيل القادم وكيفية تدريب معلم العلوم على استخدامها خلال تدريس العلوم.

Next Generation Science Standards المحور الأول: معايير العلوم للجيل القادم سمته

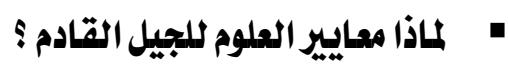
تغير العالم بشكل كبير فى الخمس عشرة سنة الماضية. حيث حدث تطور كبير فى

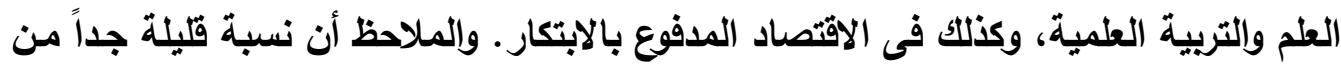
الطلاب تلتحق ببرنـامج (STEM)، ومن ثم هنـاك احتيـاج إلى معايير علميـة جديدة تحفز وتبنـي الاهتمـام بالـ STEM ـ فالنظـام التعليمسي الحسالي لا يستطيع أن يعد الطـلاب بنجـاح

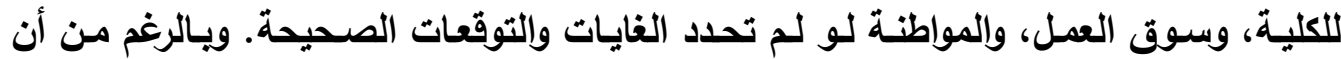
المعايير ليست هي الحل السـري لمشـاكل التعليم، فإنها تقدم الأسـاس الضـروري للقرارات المرتبطـة بـالمنهج والتقيـيم وإلتدريس. إن اسـتخدام معسيير (NGSS) سـيعمل على إعداد

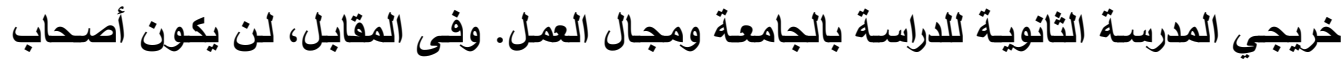
العمل قادرين على توظيف عمـال ذوي مهارات قائمسة على العلم فى مجالات محتوى علمي

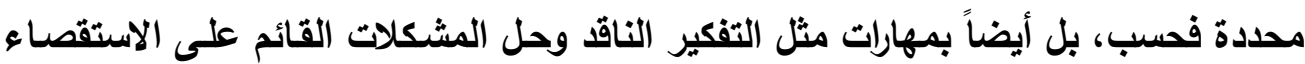
(NGSS Lead States, 2013; تعتبر الولايات المتحدة الأمريكية هي الدولـة الرائدة على مستوى العالم فى المنتجات التكنولوجية، ويالرغم من ذلك أجبرت على إعادة تقويم الواقع الفعلي لتدريس العلوم وذلك 
برنامج مقترح قائم على معايير العلوم للجيل القادم (NGSS) لتدريب معلمي العلوم بالمرحلة الإعدادية. .

(English مقارنة بالدول الآسيوية والأورويية TIMSS متيجة وضعها المتراجع فى نتائج الـ

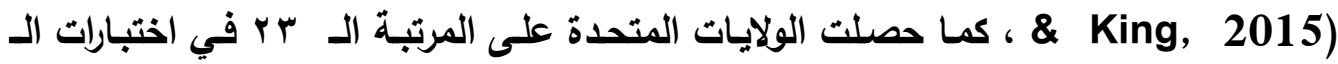
ف في العلوم، والمرتبة الـ • ب في الرياضيات. ومن ثم بدأت تفكر في تطوير تعليم العلوم والرياضيات من خلال تبني معايير جديدة تواكب المتغيرات العالمية ( حسانين، 17 ـ ب). The National وكزء من تقويم الواقع الفعل لتدريس العلوم، فإن المجلس القومي للبحث Research Council [NRC] الأمريكية الأخرى وقد نتج عن الاراسة النتائج التالية: [1] برنامج STEM ، وهو البرنامج الأكثر حداثة الذي تم الانفاق عليه ملايين الدولارات

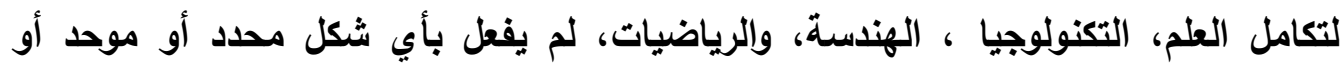
معياري. [ץ] البرامج التى تم تطويرها، مع فائدتها وضروريتها العلمية الواضحة، لم يتم تنفيذها فى فصول العلوم الدراسية الفعلية. [r] معايير العلوم القائمة لم تعد كافية للتعامل مع واقع تلريس العلوم على مستوي العالم. (Malkawy \& Rababah, 2018; NRC, 2015; Herman, 2009) ومن ثم فإن الـ [NRC] بالاشتراك مـع المؤسسـات المشـاركة أصدرت معايير العلوم

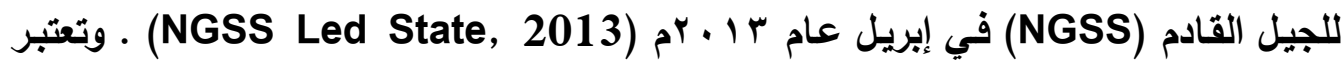
معايير (NGSS) هي أحدث معايير علوم تعليميـة للولايـات المتحدة والتي تـوفر معايير

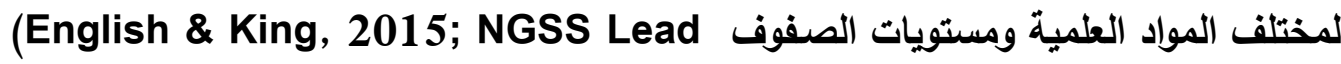
. States, 2013)

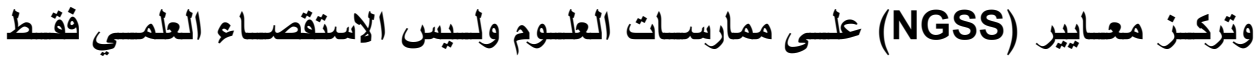
(Bybee, 2011; Duschi \& Bybee, 2014; Osborne, 2014) معلمي العلوم أن استخدام الاستقصاء فى الفصل الاراسي يعتبر تحدي بالنسبة لهم بسبب

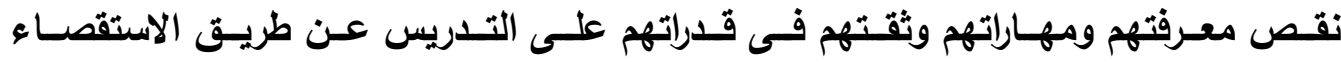
ويناء عليه، فإن إضافة ممارسـات العلوم ريما يكون مفيد لهؤلاء (Mansour , 2015) 
برنامج مقترح قائم على معايير العلوم للجيل القادم (NGSS) لتدريب معلمي العلوم بالمرحلة الإعدادية

وتهدف معايير NGSS إلى إحداث ثورة فى أساليب تدريس العلوم والوصول بنتائج

العلوم والرياضيات فى الولايات المتحدة إلى نظيراتها فى آسيا وأورويا. وقد طمت NRC فى تحقيق ذلك عن طريق:

[1] التأكيا على الأعمدة الأربعة (4Cs) [الاتصال، التعاون، الابتكارية، والتفكير الناقد]. [ץ] دمج المعايير فى العملية التعليمية مع الثورة الرقمية. [r] دمج الهندسة فى التربية العلمية عن طريق تضمين التصميم (مثل: التصميم التجريبي،

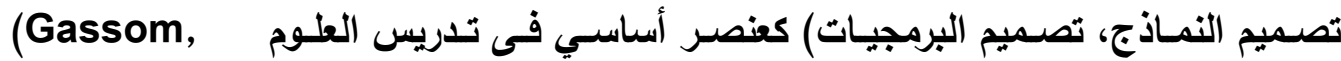
. 2013)

وقد تـم نشـر إطـار Framework التربيـة العلميـة دـ K-12 بواسـطة NRC عـام

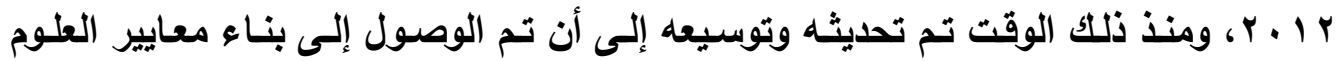
للجيل القادم (Achieve, 2013; NRC, 2012) . وتكون الفريق الأي قام بإعداد ويناء

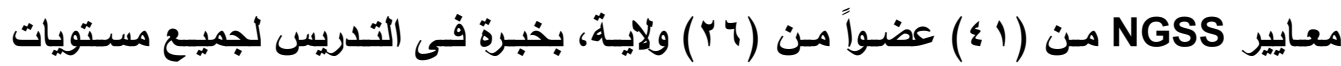
المراحل، والخبرة فى العمل مع الطلاب ذوي الاحتياجات الخاصة، والألفة بالمعايير من ولايات متعددة، والخبرة فى العديد من المجالات العلمية (NGSS, 2013a). وترتكز معايير (NGSS) على إطار التربية العلمية (K-12) : الممارسـات، والمفاهيم

Framework for K-12 Science Education: المتقاطعة والأفكار الرئيسية رئرية Practices, Crosscutting Concepts, and Core Ideas بواسطة المجلس القومي للبحث [NRC] ـ وتعتبر ممارسـات العلوم والهندسة (SEPs) هي قلب معايير العلوم للجيل القادم (NRC, 2012, pp.30-31). ويتكون كل معيار من معايير (NGSS) من ثلاثة أبعاد (NGS, 2016) )

Disciplinary Core Ideas (DCls) الأفكار الأساسية التخصية (المحتوى) [1] [r Science and Engineering Practices (SEPs) ممارسات العلوم والهندسة

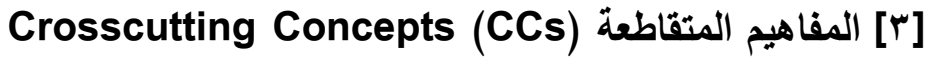
ويعكس التكامـل بـين المحتـوى التخصصـي الصـارم والتطبيق كيـف تمـارس العــوم واللهندة فى العالم الحقيقي. والجديد في معايير (NGSS) أنـه تم تصميم الـ (SEPs) والـ

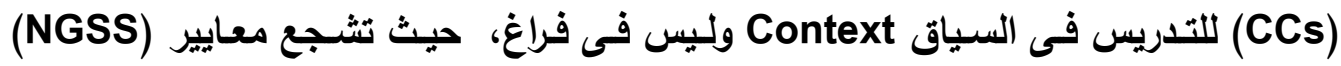


برنامج مقترح قائم على معايير العلوم للجيل القادم (NGSS) لتدريب معلمي العلوم بالمرحلة الإعدادية

على التكامل مـع مفاهيم أساسية متعددة خلال كل عام. وتبني مفاهيم العلوم بثكل متناسق

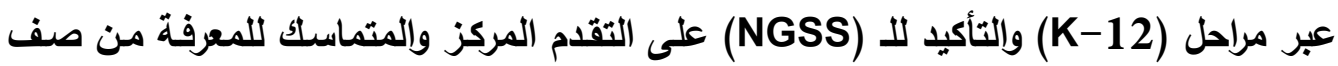

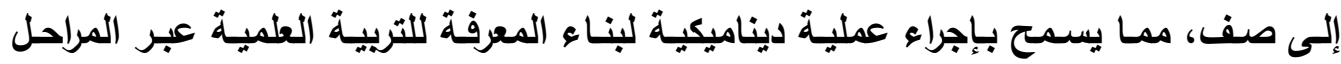
المختلفة لتعليم الطالب.

وتركـز معسيير (NGSS) على مجموعـة أصسفر مـن الـ (DCIs) والتـى يجب أن

يعرفها الطلاب عند تخرجهم من المدرسـة الثانويـة، مركزة على فهم أعمق وتطبيق للمحتوى.

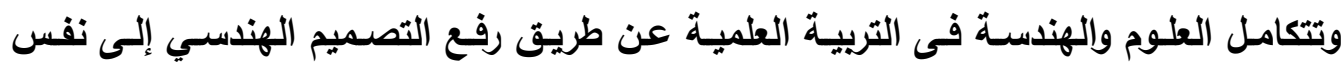
مستوى الاستقصاء العلمي فى تدريس العلوم بالفصل الدراسي عند كل المستويات وعن طريق

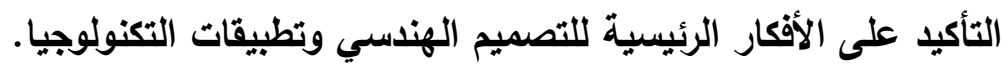
وعند وضع روئية الإطار موضع التنفيذ، تمت كتابة معايير (NGSS) كتوقعات أداء Performance Expectations (PEs) لإظهار الكفاءة فى العلوم. وتقترن ممارسات العلوم واللهندة (SEPs) مع الـ (DCls) والـ (CCs) لتشكل الـ (PEs)، ليث تم تصميم معايير (NGSS) ليقدم معلومات للمعلمين ومطوري المنهج والتقييم بما يتجاوز معيار الخط الواحد التقلياي. ويركز محتوى معايير على إعداد الطلاب للجامعة وسوق العمل. يحدد الإطار الأبعاد الثلاثة اللازمة لتزويد الطلاب بتربية علمية عالية الجودة. ويقدم التكامل لهذه الأبعاد بسياق لمحتوى العلوم، وكيف يتم فهم وإكتساب المعرفة العلمية، وكيف ترتبط العلوم الفرديـ Individual Sciences Sن خـلال المفاهيم التى لها معنى عالمي عبر التخصات. ويمكن عرض الأبعاد الثلاثة لمعايير (NGSS) كما يلي: NGSS Lead)

States (2013)

البعد الأول : ممارسات العلوم والهندسة Science and Engineering Practices (SEPs) وهو البعد الخاص بالبحث الحالي. وينيت ممارسـات العلوم واللهندسة (SEPs) من المعرفـة والأفعـال المستخدمة بواسـة العلمـاء لبنـاء النمـاذج أو التحقق مـن النظريـات عن وبن العالم، أو أن المهندسين يستخدمونها لبناء وتصميم النظم. والإندماج فى الممارسـات العلمية يسـاعد الطـلاب على فهم كيفيـة نمـو المعرفة العلميـة، أيضـاً إندماج الطلاب في ممارسـات 
برنامج مقترح قائم على معايير العلوم للجيل القادم (NGSS) لتدريب معلمي العلوم بالمرحلة الإعدادية

الهندسة يساعدهم على فهم عمل المهندسين، وكيف يمكن للمهندس حل المشكلة. ويصف هذا البعد كل من:

(أ) الممارسـات الأساسية التى يوظفها العلمـاء عند قيامهم بـالفحص العلمي وينـاء النمـاذج والنظريات عن العالم.

(ب) مجموعة ممارسات الهندة التى يستخدمها المهندسون عند تصميمهم وينائهم للنظم . Skills "بداًً من مصطلح "المهارات للتأكيا على الاندماج فى متطلبات الفحص العلمي وليس المهارة فقط ولكن أيضاً المعرفة المحدة لكل ممارسة. بطريقة مماثلة، لأن مصطلح "الاستقصاء" Inquiry المشار إليه على نطاق واسع فى وثائق المعايير السابقة تم تفسيره عبر الزمن بعدة طرق مختلفة فى مجتمع التربية العلمية، وجزء من المقصود بتوضيح الممارسات فى البعد الأول هو تحديد أفضل للمقصود بالاستقصاء فى العلوم والممارسات المعرفية، والاجتماعية، والمادية المطلوية بشكل أفضل.

البعد الثاني: المفاهيم المتقاطعة ( الشاملة ) Crosscutting Concepts: ترجـع المفـاهيم المتقاطعة إلى طرق الريط للأفكار الرئيسية والنظم. وهذه المفـاهيم تفسر الموضوعات العلمية التى تظهر فى كل النظم العلمية، والتى تمكن الطلاب من تنمية فهم تراكمي ومتماسك لطرق العلوم والهندة. فالمفاهيم الشاملة هي مفاهيم لها تطبيق فى في

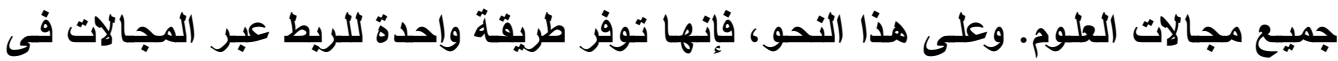

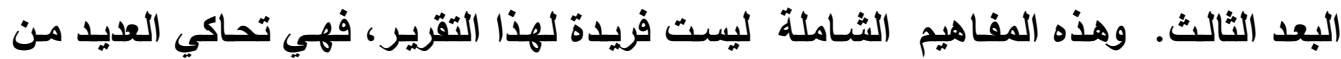
المفاهيم الموحدة Unifying Concepts والعمليات فى المعايير القومية للتربية العلمية (NSES)، والمواضـيع المشـتركة في العلامسات المرجعيـة Benchmarks للتنـور العلمـي. ويحدد الإطار (V) مفاهيم شـاملة (CCs) تقدم للطلاب تركيب منظم لفهم العالم وتسـاعدهم على صناعة معنى وارتباط بين الـ (DCls) عبر التخصصـات والمراحل، وهي غير مقصودة كمحتوى إضافي، ومثلها مثل الـ (SEPs) ليست لها نقطة نهايـة عبر المراحل لكنها مستمرة عبر المراحل، والـ (CCs) هي: الأنمـاط ، السبب والنتيجـة، المقيـاس - النسبة - والكميـة، النظم ونماذج النظم، الطاقة والمادة فى النظم، التركيب والوظيفة، ثبات وتغير النظم. 
برنامج مقترح قائم على معايير العلوم للجيل القادم (NGSS) لتدريب معلمي العلوم بالمرحلة الإعدادية

البعد الثالث: الأفكار الأساسية التخصصية Disciplinary Core Ideas وهي الأفكار التي تهذف إلى إعداد الطلاب بمعرفة أساسية كافية والتي تمكنهم من الحصول على معلومات إضافية بطريقتهم الخاصـة بدون المعلم. فمعايير (NGSS) ترى إنـه يجب التركيز على هيئة محددة من الأفكار فـى مجال العلوم والهندسـة وتضـمين تفسيرات للظواهر المتعددة ـ فالتوسيع المستمر فى المعرفة العلمية يجعل من المستحيل تدريس كل

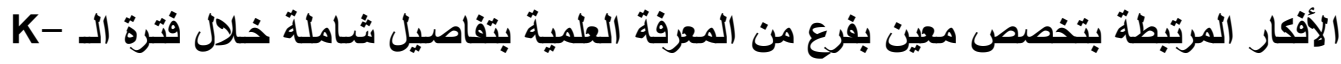
12. ولكن بالنظر إلى وفرة المعلومـات المتاحة اليوم فى الواقع الذي يعيشـه الناس، فئإن

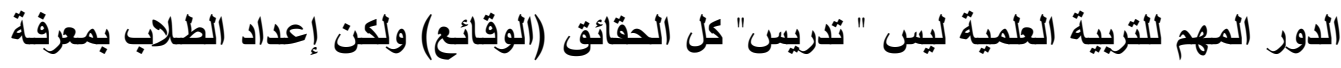

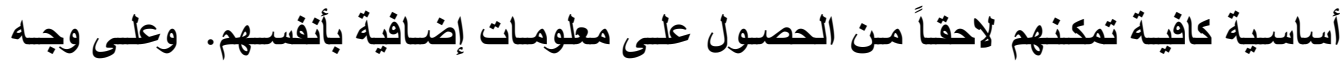
التحديد، يجب أن تتميز الفكرة (العلمية) الأساسية لتدريس العلوم من K إلى Y I بما يأتي:

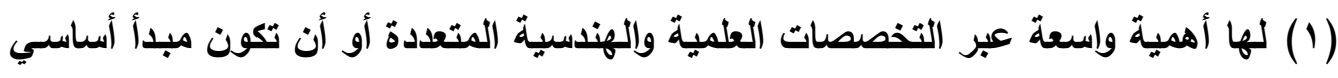
التنظيم تخصص معين.

(Y) توفر أداة رئيسة لفهم أو تقصي واستكثاف المزيد من الأفكار المعقدة وحل المشكلات.

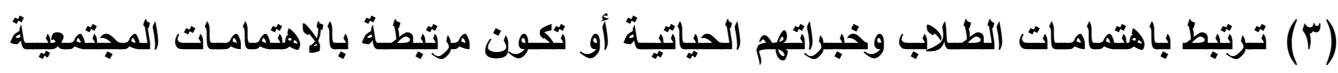
والثخصية والتى تتطلب معرفة علمية أو تكنولوجية.

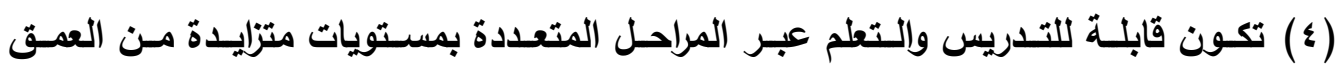
والتعقيد.

وفى تنظيم البعد الثالث، تم تجميع أفكار النظم بـاخل (ع) أبعاد رئيسـة هي: العلوم الطبيعية، علوم الحياة، علوم الأرض والفضاء، واللهندة والتكنولوجيا وتطبيق العلم. في نفس الوقت توجد الإرتباطات Connections المتعددة بين الأبعاد. حيث يعمل الإدمل العلماء أكثر فأكثر بشكل متكرر فى فرق متعددة التخصصات والتي تعمل على طمس الحدود

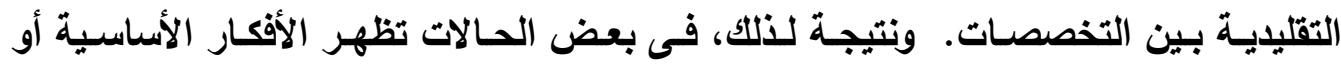
العناصر الأساسية فى العديد من التخصصات (علي سبيل المثال، الطاقة (NRC, (Energy) (2012. والإبتكار الحقيقي فى معايير (NGSS) هو عمل الطلاب عند نقاط التداخل بين الممارسة والمحتوى والارتباط (NGSS, 2013). 
برنامج مقترح قائم على معايير العلوم للجيل القادم (NGSS) لتدريب معلمي العلوم بالمرحلة الإعدادية.

وتمثل توقعات الأداء Performance Expectations (PEs) الطريقة الصحيحة

لتكامل وارتباط الأبعاد الثلاثة. فهي توفر التحديد للمعلمين لكيفية ظهور التربية العلمية فى الفصـل الدراسـي. وإذا نفـت بشـكل صـيح، فسـوف تـؤدي معـايير (NGSS) إلى تـدريس متماسك وصـارم والذي ينتج عنه أن يكون الطلاب قادرين على اكتسـاب وتطبيق المعرفة العلمية فى مواقف محددة والتفكير والإستدلال بشكل علمي(NRC, 2012) ، وتتمثل روئة التربية العلمية فى القرن الحادي والعشرين فى أن كل الممارسـات Practices متوقع أن يتم

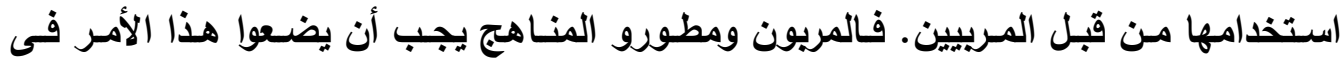
الحسبان أثناء تصميمهم للتدريس لتطوير معايير (NGSS)، حيث كانت المشكلة الرئيسية فى تطوير الـ (PEs) هي الاختيار الفعلي للممارسات مع الـ (DCls) والـ (CCs)، والكلمـات

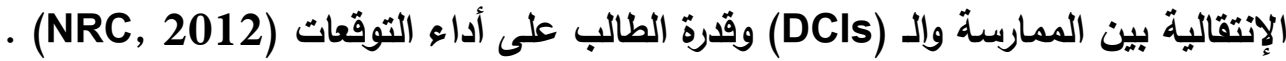
• اعتبارات تصميم معايير (NGSS) وعلاقتتها بممارسات العلوم والهندسة (SEPS) ؛ ( 1 ) اقتران الممارسة مع المحتوى :

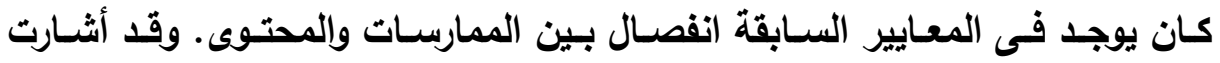
الدراسـات السـابقة إلى أنـه كان يتم تدريس هذين المكونين بثكل منفصل أو لا يتم تدريس

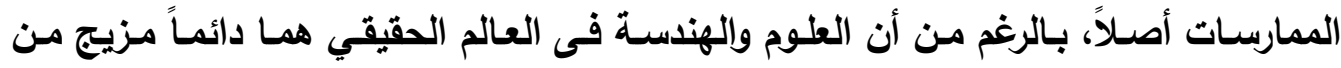

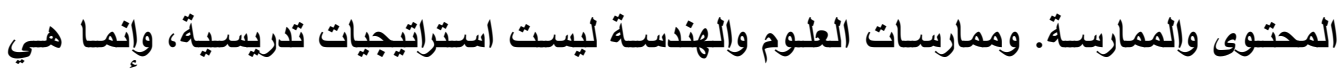
مؤثثرات للإنجاز بالإضـافة إلى كونها أهداف تعليمية مهمـة في حد ذاتها. ويضمن الإطار

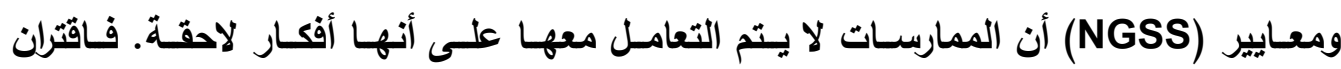

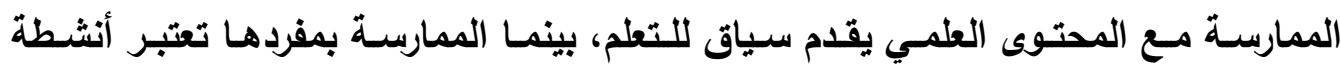
والمحتوى بمفرده يؤدى إلى حفظ المعلومـات Memorization. ومـن خـلال هذا التكامـل Integration

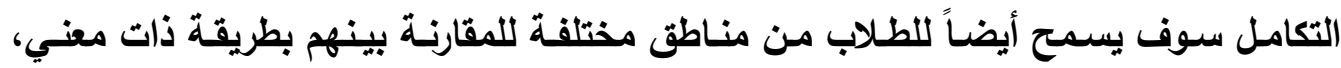

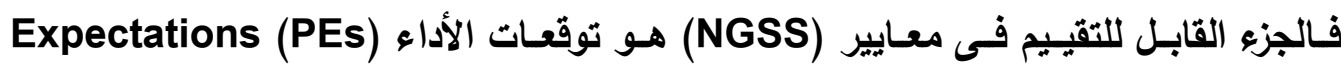




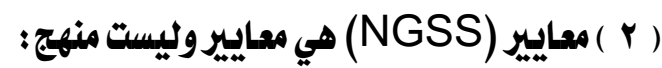

إن معايير (NGS) هي معايير، أو غايـات، والتي تعكس مـا الذي يجب أن يعرفه

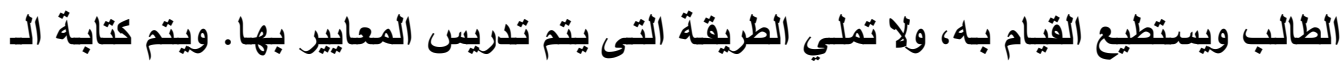
(PEs) المنهجية والتدريسية للولايات والمقاطعات والمدارس والمعلمين.

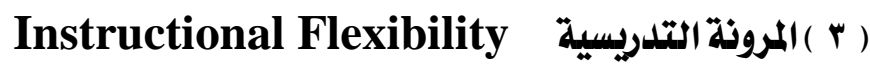
بمـا أن معـايير (NGSS) هـي أداعات مـن المفتـرض إنجازهـا فـى نهايـة التـريس، فالتدريس الجيد سـوف يجعل الطلاب يندمجون فى العديد من الممارسـات خـلال التدريس.

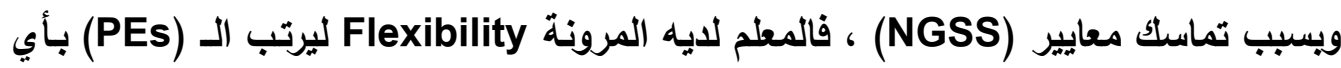

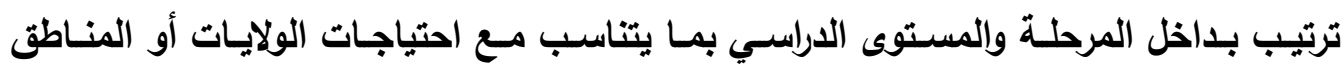

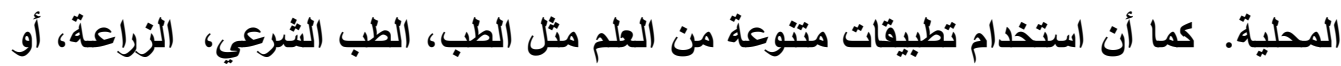

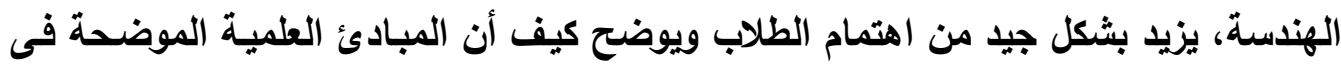
الإطار والمعايير تطبق فى مواقف العالم الحقيقي (NGSS Lead States, 2013). ونستخلص من العرض السـابق للمحور الأول أنه كان لابـ من ظهور معايير العلوم

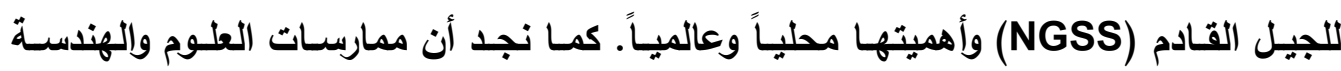

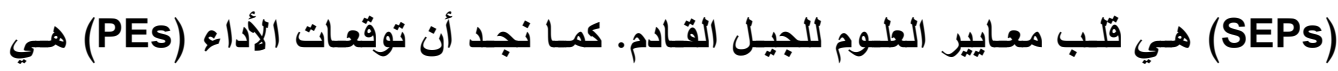
الاختلاف الجوهري بين معايير (NGSS) والمعايير الأخرى والتي تعمل على الالتحام بين

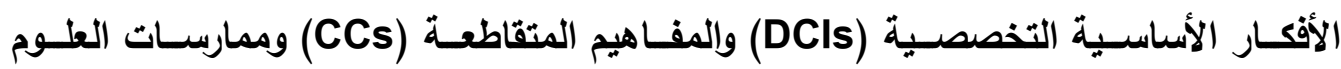
والهندسة والتي سيتم تناولها بشكل مفصل في المحور التالي.

المحور الثاني : تلدريب معلمي العلوم على استخدام ممارسات العلوم والهنلسة أثناء التدريس : Science and Engineering Practices [SEPs] العلم ليس مجرد مجموعة من المعارف التي تعكس الفهم للعالم، ولكن أيضاً مجموعة

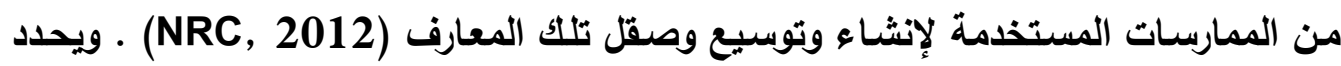
إطار التربيـة العلميـة Framework ومـن بعده معايير العلوم للجيل القادم (NGSS (NGS) ممارسات للعلوم والهندسة (SEPs) والتي تعكس ممارسات العلماء والمهندسين المحترفين.

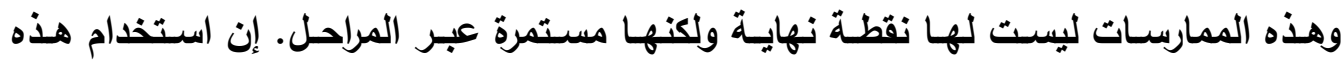


برنامج مقترح قائم على معايير العلوم للجيل القادم (NGSS) لتدريب معلمي العلوم بالمرحلة الإعدادية

الممارسـات ليس فقط بهدف تقويـة مهارات الطلاب في هذه الممارسـات لكن أيضـاً لتنميـة فهمهم لطبيعة العلم وإلهندسة.

ويستخلم الإطار مصطلح "الممارسات " Practices وليس " عمليات العلم " أو مهارات الاستقصاء لسبب محدد والأي ورد بوثيقة الإطار كما يلي : " نحن نستخدم مصطلح " الممارسات " بدلاً من مصطلح مثل " المهارات" ليؤكد على أن الاندماج فى الفحص العلمي يتطلب ليس فقط المهارات ولكن أيضاً المعرفة الخاصة بكل ممارسة (NRC, 2012). The National Research Council وعندما أصدر المجلس القومي للبحث

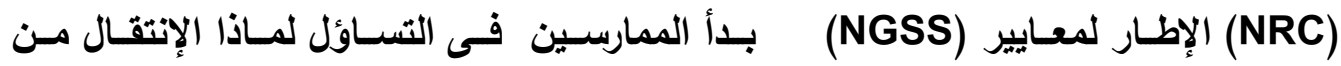
(Osborne, 2014; Science Practices الاستقصاء العلمي إلى ممارسات العلوم . Bybee, 2011)

وفي هذا الصدد أشار (2011) Bybee إلى أن الإستقصاء العلمي شكل واحد من

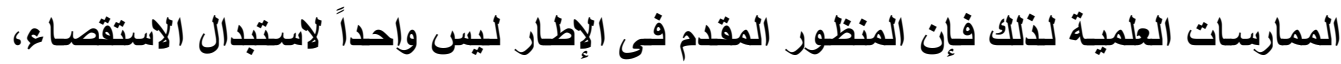
ولكنه لتوسيع وإثراء تدريس وتعلم العلوم · وينمـا يري Bybee أن الاستقصاء العلمي أحد

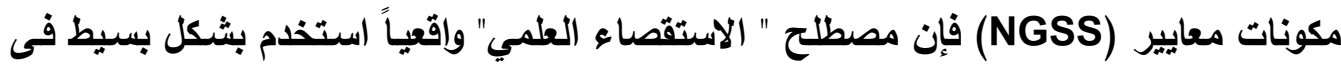
الإطار والمعايير الجديدة(Kawasoki, 2015) ، كما أن مصطلح الاستقصاء العلمي غير منتشـر فـى معسايير (NGSS) بسـبب أن الدراســات السـابقة أوضـــت أن المعلمسين قـاموا باستخدام الاستقصـاء العلمي بشكل غير منتج أدي إلى تكوين تصورات خاطئة فيما يتعلق

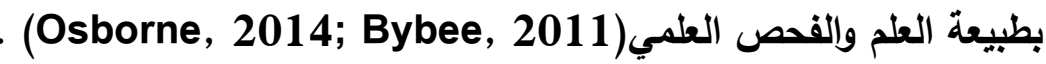

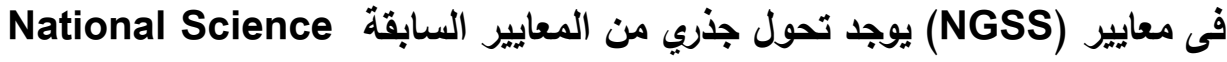
Education Standard (NSES, NRC, 1996) محتوى صـارم إلى تأكيد جديد على مسـاعدة الطلاب على المشـاركة في ممارسـات العلوم ملـي واللهندة. وترى معايير (NGSS) أن ممارسات العلوم واللهندة (SEPs) تعمل كقنوات للطلاب ليندمجوا معاً ويتعلموا عن العلوم (Bybee, 2011; Osborne, 2014) . . ومعايير لا تضيف فكرة الفصل بين المحتوى العلمي وعمليات العلم كمـا هو موجود في (NGSS) معايير (NSES) من خلال وجود مجموعة من المعايير للاستقصاء والتجريب منفصلة عن 
برنامج مقترح قائم على معايير العلوم للجيل القادم (NGSS) لتدريب معلمي العلوم بالمرحلة الإعدادية

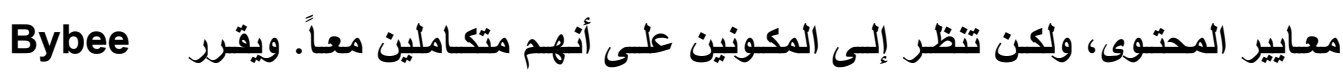
(2011) أنـه عندما يندمج الطلاب في الممارسـات العلمية فالأنشطة تصبح أسـاس التعلم عن التجارب والبيانات والدليل، وإلمناقثة الاجتماعية، والنماذج والأدوات، والرياضيات وتطوير التهمير القدرة على تقويم الإدعاءات المعرفية، وإجراء الاستقصاءات التجريبية، وتطوير التفسيرات (NRC, 2012).فروئية المحتوى العلمي والممارسـات العلمية بشكل متكامل تأتي بمتطلبات جديدة وأهداف للمعلمين لفهمها وتضمينها بداخل تدريسهم. ويشير الإطار أن كل توقع أداء Performance Expectation يجب أن يجمع بين ممارسـة مـن ممارسـات العلـوم والهندسـة ذات صـلة بأحس الأفكـار الرئيسية المحوريـة والمفـاهيم الثـاملة وتكون مناسبة للطلاب بمستوى المرحلة التي تصسم مـن أجلها. وريمـا يكون هذا الخط الموجه هو الطريقة الأكثر دلالة وأهمية والتى تختلف فيها معايير (NGSS) عن وثائق المعايير السابقة. وتتمثل ممارسات العلوم والهندسة (SEPs) بمعايير العلوم للجيل القادم في: [1] طرح الأسئلة ( في العلوم ) وتحديد المشكلات ( في الهندسة ). [ץ] [ تطوير واستخدام النماذج. [r] [بطيط وتتفيذ الإستقصاءات (التحقيقات). [ [ ] تحليل وتفسير (ترجمة) البيانات. [0] استخدام الرياضيات والتفكير الحوسبي. [־] بناء التفسيرات وتصميم الحلول. [V] الاتدماج فى الحجة باستخدام الاليل( المحاجة وإقامة الدليل ). [1] الحصول على المعلومات وتقويمها وتواصلها ( التواصل بواسطتها). وفيما يلي عرضاً تفصيلياً لكل ممارسة من الممارسات بشيء من التفصيل مع عرض ونه

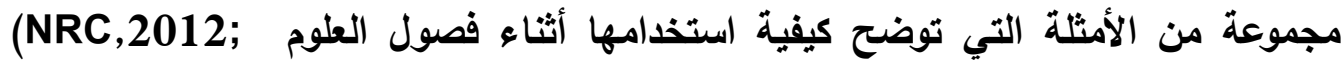
:NGSS, 2013) ممارسة ( 1 ): طرح الأسئلة ( في العلوم ) وتحديد المشكلات ( في الهندسة ): الأسئلة هي المحرك Engine الذي يقود العلم والهندسة (NRC, 2012). 
- ما الأي يمكن القيام به لتلبية حاجة أو رغبة إنسانية معينة ؟

- - كيف يمكن تحديد الحاجة بشكل أفضل ؟ - - ما هي الأدوات والتكنولوجيات المتاحة أو التي يمكن تطويرها من أجل تلبية هذه الحاجة

• كلاً من العلوم والهندسة تسأل:

- - كيف يتم التواصل حول الظواهر والأدلة والتفسيرات وحلول التصميم ؟ إن طرح الأسئلة أمر ضروري لتطوير عادات العقل العلمية Habits of Mind ، وحتى بالنسبة للأفراد الذين لا يصبحون علماء أو مهندسين، فإن القدرة على طرح الأسئلة المحدة هي مكون مهم من مكونات التنور العلمي، ويساعدهم على أن يصبحوا مستهلكين ناقدين للمعرفة العلمية. وتنشأ الأسئلة العلمية من خلال طرق متتوعة. فيمكن أن تنشأ الأسئلة من خلال حب الاستطلاع عن العالم ( مثال: لماذا السماء زرقاء ؟) ، كما أنها يمكن أن تكون مستوحاه من تنبؤات نموذج أو نظرية خلال محاولة توسيع أو تحسين النموذج أو النظرية ( مثال: كيف يفسر نموذج الجسيمات للمادة عدم الانضغاط في السوائل ؟)، أو يمكن أن تنتج من الحاجة

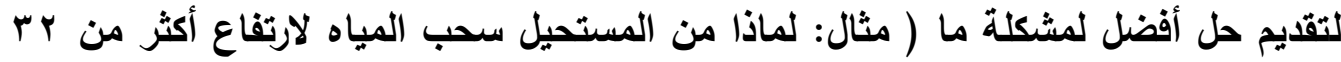
قام ؟ فقد أدى هذا السؤال إلى قيام Evangelista Torricelli ( تورشيلي ) في القرن الـ IV إلى اختراع البارومتر واكتثافاته حول الغلاف الجوى. اخترع العالم الإيطالي إيفانجليستا توريشلي البارومتر عام بـ 1 ا م. وأثبث توريشلي أن الضغط الجوي يعادل تقريبا وزن عمود من الزئبق طوليه VY سم. حيث إن قوة الضغط الجوي هي السبب في تحديد ارتفاع الماء أو الزئبق في الأنبوب، فكلما كان الضغط أقوى، كانه كان الارتفاع أعلى ). 
برنامج مقترح قائم على معايير العلوم للجيل القادم (NGSS) لتدريب معلمي العلوم بالمرحلة الإعدادية.

والأسئلة مهمة أيضاً في الهندة. فالمهندسون يجب أن يكونوا قادرين على طرح أسئلة قابلة للتحقق لكى يحددوا المشكلة الهندسية، على سبيل المثال، يمكن أن يسألوا: ما هي الحاجة

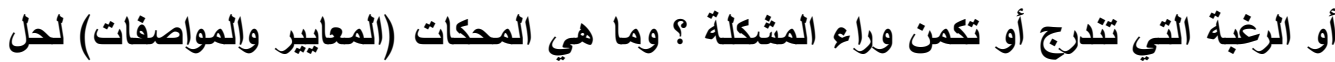
ناجح ؟ وما هي القيود ؟ ـ وتتشأ أسئلة أخرى عند توليد الحلول الممكنة مثل: هل يلبي هذا الحل معايير التصميم ؟ هل يمكن الجمع بين فكرتين أو أكثر لإنتاج حل أفضل ؟ ويجب أن يكون الطلاب في أب مستوى من الصفوف قادرين على طرح أسئلة لبعضهم البعض حول النصوص التي يقرؤونها، والظواهر التي يلاحظونها، والاستتتاجات التي يستخلصونها من نماذجهم أو من التحقيقات العلمية (NRC, 2012). وتتضمن هذه الممارسة التمييز بين السؤال العلمي والسؤال غير العلمي، وطرح الأسئلة عن العالم الطبيعي والبشري ، بالإضافة إلى صياغة الأسئلة التي يمكن الإجابة عليها تجريبياً، وطرح الأسئلة التي تهدف إلى بناء حجة علمية، وطرح أسئلة حول قيود ومواصفات الطلول للمشكلات، وصياغة أسئلة تؤدي إلى ممارسات علمية إضافية، وطرح أسئلة أو مشكلات قابلة للاختبار، وأخيراً طرح أسئلة قائمة على حب الاستطلاع الناقد. ممارسة ( r ) : تطوير واستخلام النماذج : يبني العلماء النماذج العقلية والنمـاذج المفاهيمية للظواهر المختلفة. والنماذج العقلية Mental Models بشـكل أساسـي. وتعمـل النمـاذج العقليـة كـأداة للتفكير، ولصــاعة التبــوأت، وينـاء المعنـي. والنمـاذج المفاهيميـة Conceptual Models في المقابـل هي تمثيلات خارجيـة واضـحة تثبه في بعض الأحيان الظواهر التي تمثلها. وتسمح النماذج المفاهيمية للعلماء وإلمهندين بتصور الظاهرة قيد البحث، وفهمها بشكل أفضل، أو تطوير حل ممكن لمشكلة تصميم. ومن أمثلـة النمـاذج المفاهيميـة: المخططات، التمثيلات الرياضية، ونمـاذج المحاكـاة الكمبيوتريـة. وتسـاعد هذه النمـاذج في التركيز مـع ضرورة الأخذ في الاعتبار القيود والحدود للاستخدام،

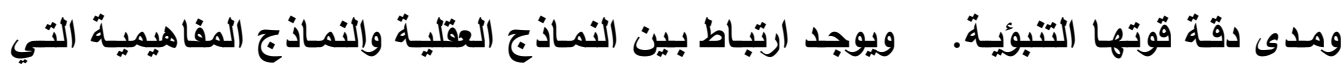
يمكن أن تساعد على فهم أعمق للعلوم وتعزز القدرة على التفكير الاستدلالى. كما تساعد النماذج الإكترونية التفاعلية العلماء في التتبؤء بالسلوك، وعلى سبيل المثال: التتبؤُ بتأثير زيـادة مستويات CO2 في الغـلاف الجـوي على الزراعـة في منــاطق 
مختلفـة مـن العـالم. ويمكن تقيـيم النمـاذج وصـقلها وتعـديلها لتتوافق مـع العـالم الـواقعي. وتستخدم الهندسـة النمـاذج لتحليل النظم، وتحديد الحلول الممكنة للمشكلات الجديدة، كمـا يستخدم المهندسون النماذج لبناء وتصور التصمير، وتحسينة، والاختبار الأولى لأداءه. كما

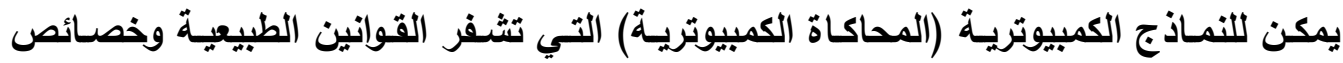
المواد أن تستخدم في اختبار التصميمات للهياكل مثل المباني والجسـور والطائرات، والتي تكون باهظة الثمن وتتطلب أن تصمد أمسام الظروف القاسية التي تحدث في مناسبات نادرة. ويجب الأخذ في الاعتبار أنـه كمـا هو الحـال في العلوم، يجب أن يكون المهندسون الذين

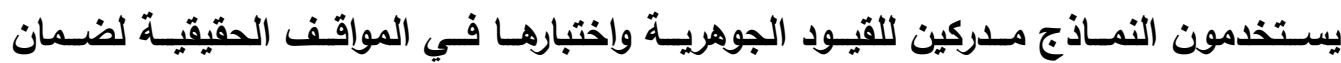
موثوقيتها (NRC, 2012).

وتتضمن النماذج أيضاً بناء الرسوم والمخططات لتمثيل الأحداث أو النظم أو الظواهر

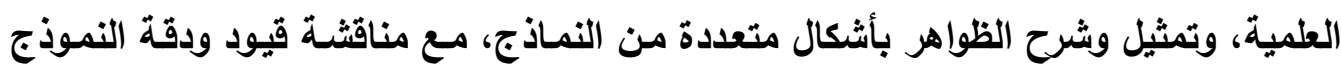
كتمثيل لنظام أو عملية أو تصميم، وإقتراح طرق لتحسين النموذج، بالإضافة إلى استخدام النماذج الإكترونية التفاعلية كأداة لفهم وتقصي الظواهر المختلفة، مع بناء واستخدام نموذج لاختبـار تصـيم معين أو أحد جوانب التصـيم، ومقارنـة حلـول التصـيم المختلفـة، وأيضـاً

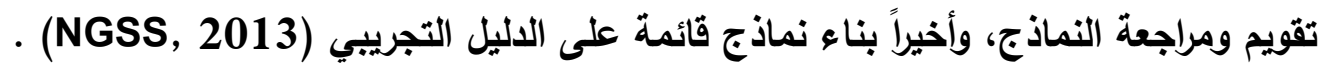
ممارسة ( r ) ) تخطيط وتنفيذ التحقيقات العلمية ؛ وتتضـمن صياغة سـؤال يمكن التحقق منـه بـاخل الفصل أو المعمل أو الحقل بمسـاعدة

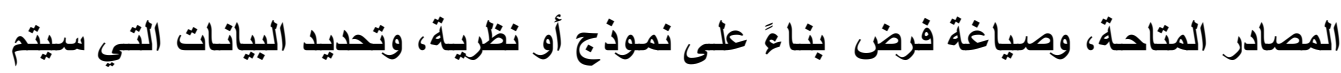
جمعها، وما هي الأدوات اللازمة لجمع البيانات، وكيف سيتم تسجيل القياسـات، وأيضاً تحديد

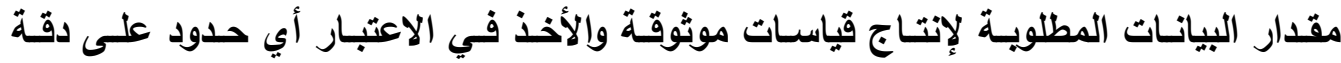
البيانـات، بالإضـافة إلى تخطيط إجـراءات البحث الميداني أو التجريبـي، وتحديد المتغيـرات المسـتقلة والتابعـة، و الضـابطة، والتأكلد مـن أن التصـيم قـام بضـبط المتغيـرات أو التأثيرات المريكة المحتملة. مهارسة ( ) ) : تحليل وترجمة البيانات : وتتضمن تحليل البيانات بشكل منهجي للبحث عن الأنماط البارزة، و اختبار مـا إذا كانت متسـقة مـع فرض مبلئي، وتمييز متسى تكون البيانـات متعارضـة مـع التوقعـات والأخـذ في 
برنامج مقترح قائم على معايير العلوم للجيل القادم (NGSS) لتدريب معلمي العلوم بالمرحلة الإعدادية

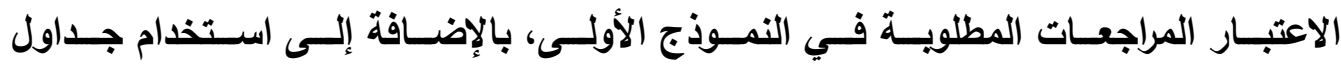

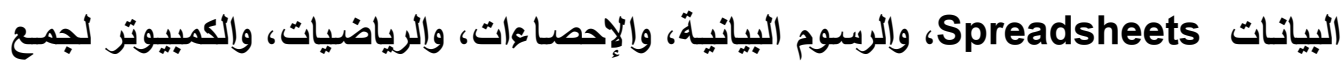
وتلخيص وعرض البيانات، ولاستكشـاف العلاقات بين المتغيرات، وتقويم مدى قوة الاستتتاج الذي يمكن استنتاجة من مجموعة من البيانات وذلك باستخدام تكنيكات رياضية وإحصائية بمـا يتناسب مـع مستوى الصف الاراسي، مـع تمييز الأنمـاط في البيانـات مثل التمييز بين العلاقات السببية والارتباطية بالإضـافة إلى تحويل البيانـات إلى تمثيلات بيانية، مـع التحليل الإحصائي للبيانات لإظهار الأنماط والعلاقات، والقدرة على تحديد مصادر الخطأ (التجريبي مثلاًا)، وأخيراً جمع البيانات من النمـاذج الفعلية وتحليل أداء التصميم في إطار مجموعة من الإن الثروط .

\section{ممارسة ( 0 ) : استخلام الرياضيات والتفكير الحوسبي:}

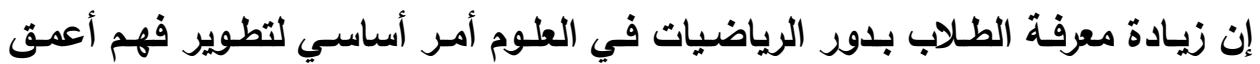
لكيفية عمل العلم (NRC, 2012). وتتضمن هذه الممارسـة تمييز كميات الأبعاد وإستخدام الوحدات المناسبة في التطبيقـات العلميـة للصيخ الرياضية والرسبوم البيانيـة، والتعبير عن هن العلاقات والكميات في أشكال رياضية مناسبة للنمذجة العلمية والتحقيق العلمي، و استتناج أن المحاكـاة الكمبيوتريـة تبنى على نمـاذج رياضية قائمسة على الافتراضـات المندرجـة تحت الظواهر أو النظم التي يتم دراستها، بالإضـافة إلى استخدام حالات اختبار بسيطة للتعبيرات

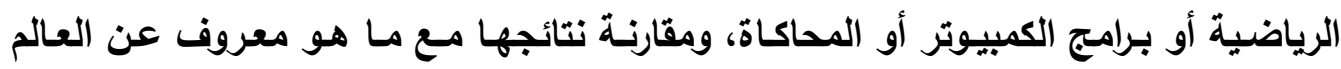

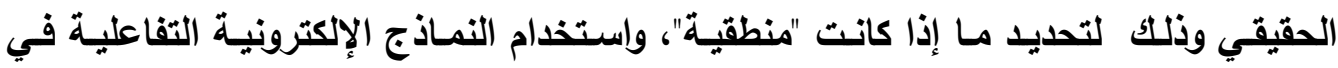
إجراء اختبارات ومقارنـة نتائجها بمـا هو موجود بـالواقع، وإستخدام المستوى المناسب لفهم الرياضـيات والإحصـاء بالصـف الاراسـي في تحليـل البيانـات، وعمـل تنبـؤات كميـة، وتحديـ الأنمـاط والعلاقـات، وأخيراً استخدام الأدوات الرقميـة مثل ( الكمبيـوتر ، الألـة الحاسبة) عند التعامل مع مجموعة كبيرة من البيانات. ممارسة ( 7 ) بناء التفسيرات وتصميم الحلول : وتتضمن بنـاء التفسيرات الخاصـة بـالظواهر العلميـة باستخدام المعرفة لنظريـة علميـة مقبولة وريطها بالنماذج والأدلة، مع استخدام الدليل العلمي والنماذج لتدعيم أو دحض تفسير ظاهرة ما، بالإضافة إلى تدريب الطلاب على تقديم تفسيرات سببية مناسبة لمستوى معرفتهم 
برنامج مقترح قائم على معايير العلوم للجيل القادم (NGSS) لتدريب معلمي العلوم بالمرحلة الإعدادية

العلميـة ، وتـدريبهم على تعديد الثفرات أو نقـاط الضـعف في التفسيرات الخاصـة بهـم أو الخاصـة بـالآخرين، مـع حـل مشــاكل التصـميم مـن خـلال تطبيـق المعرفـة العلميـة، والقيـام بمشـاريع التصميم، والاندماج في خطوات دورة التصميم وإنتاج خطة تلبي معايير التصميم المحددة بالإضـافة إلى تصميم أداة أو ( جهاز) ، وفي النهايـة تقويم ونقد حلول التصميم المتنافسة القائمة على أساس معايير التصميم المتفق عليها. ممارسة ( V ) : الاندماج في الحجة العلمية بـاستخلام الدليل ( المحاجة وإقامة الدليل ) ؛ وتتضمن بنـاء حجة علميـة توضـح كيفية تلعيم البيانـات للادعاءات، وتحديد نقاط القوة والضعف في الحجج العلمية، ومناقشتها باستخدام الاستدلال واللاليل، وتدريب الطلاب على

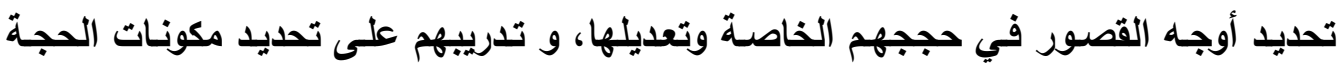

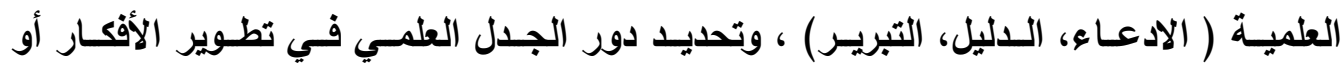

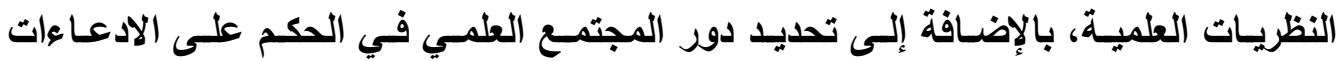
العلمية من خلال مراجعة الاقران Peer Review ، وقراعة تقارير وسـائل الاعلام عن العلوم والتكنولوجيا بشكل ناقد لتحديد نقاط القوة والضعف فيها، مع تدريب الطلاب على تقويم حجج الآخرين، والتدريب على تقديم الأدلة الكافيه التى تدعم صحه ادعاء معين، وأخيراً التدريب على تقديم الحجج المضادة. ممارسة ( 1 ) الحصول على المعلومات وتقويمها وتواصلها ( التواصل بواسطتها ) : وتتضمن استخدام الكلمات، الجداول، الأشكال التخطيطية، والرسوم البيانية ( ورقياً أو

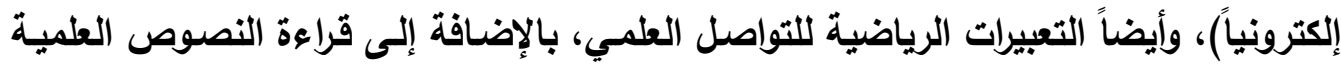

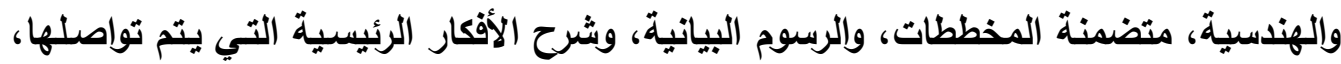
مـع القدرة على انتـاج نص مكتوب ومعروض أو القيام بعرض شـفوي والعمل على تواصل الأفكار والإنجازات، بالإضـافة إلى الاندماج في القراءة الناقدة للأدبيـات العلمية الأوليـة، أو

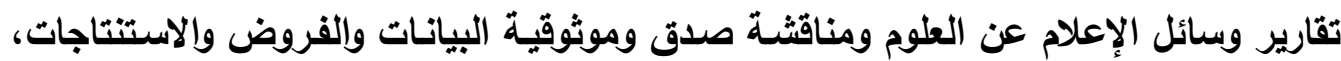
(NRC, 2012; أخيراً التقويم الناقد لقيمة وصدق النصوص والحجج والمحادثات العلميـة 
برنامج مقترح قائم على معايير العلوم للجيل القادم (NGSS) لتدريب معلمي العلوم بالمرحلة الإعدادية.

• آليات تفعيل استخدام ممارسات العلوم والهندسة [SEPS] أثناء تلدريس العلوم : حد (2014) Kloser ثلاثة متطلبات للمعلمين لتفعيل استخدام ممارسات العلوم وإلهنسة بمعايير (NGSS) وهي: [1] [الفهم العميق لأهداف ممارسات العلوم وإلهندسة. [ץ] [ إدارة وتنظيم حديث الطالب. [r] نقل مسؤولية التعلم إلى الطالب.

( 1 ) الفهم العميق لأهداف ممارسات العلوم والهنلدسة :

أوضحت الدراسات السابقة كيف أن أهداف ومعتقدات وفهم المعلمين عن الإصـلاح (Kawasaki, فى التربية العلمية يؤثثر على الطرق التي يتحقق بها الهـف من الإصلاح $.2015)$ فقد هدفت دراسـة (2015) Kawasaki إلى إجراء مستح ومقابلة لسبع معلمين

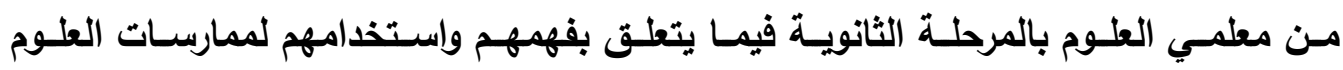

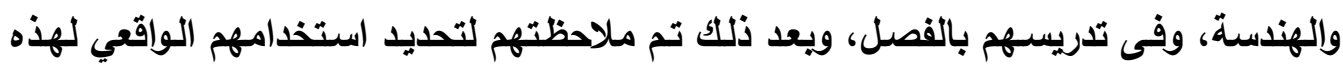

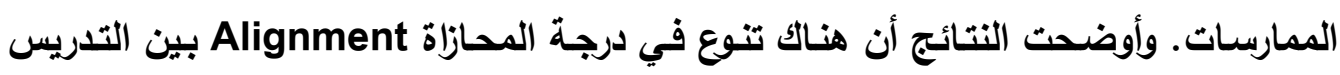
الموصوف من قبل المعلم والملاحظ بالفصل الدراسي وغايات معايير(NGSS) ـ فعلى سبيل المثال، فإنه كان أسهل للعديد من المعلمين وصف التدريس حول ممارسـات العلوم والهندسة التي تحسازي أهداف (NGS) أكثر من القيام بالتدريس الذي يحسازي المعـيير. وأرجعت

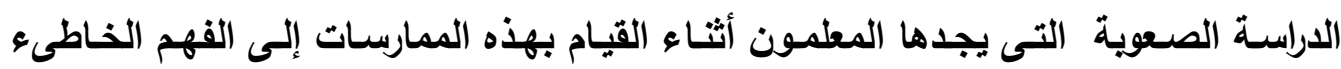
لهذه الممارسات. وأوصت الدراسة ب بعض ملامتح النمو المهني التى يمكن أن تدعم المعلمين فى تحسين فهمهم، وأهدافهم، وتدريسهم بالفصل الدراسي فيما يرتبط بهذه الممارسات.

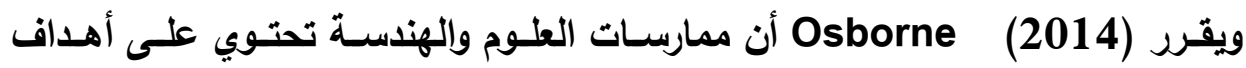
مختلفة والتي تخدم أغراض مختلفة، وأن تدعيم فهم المعلم لكل هدف من الأهداف سوف

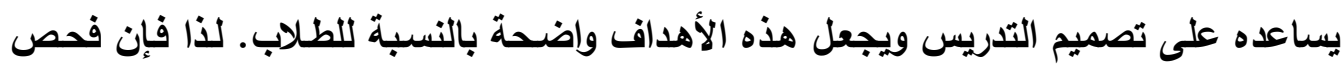
الفهم المبئي للمعلم لأهداف معايير (NGSS) متضمنة ممارسات العلوم وإلهندسة (SEPs) يقدم قاعدة أساسية لتصميم أنشطة النمو المهني، كما يمكن أن يقدم تصور عن التفاعلات اللاحقة مثثل المناقشـات غير الرسمية، وملاحظات الفصل الدراسي، والمقابلات مـع المعلمين 
برنامج مقترح قائم على معايير العلوم للجيل القادم (NGSS) لتدريب معلمي العلوم بالمرحلة الإعدادية.

Craw ford, Gapps, Van Driel et al., 2013) المهني يمكن حينئذ أن تهذف إلى مواعمة أهداف المعلمين مع التعريفات والأهداف الموضحة فى معايير العلوم للجيل القادم (Allen \& Penuel, 2014; Moon et al., 2012).

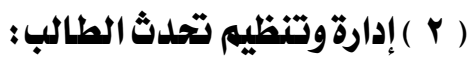

إن تلدعيم وتعزيز حوار Discourse الطالب يعتبر ملمسح أساسي في معايير (NGSS)

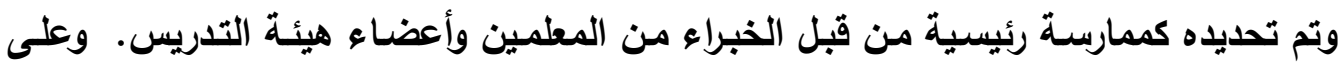

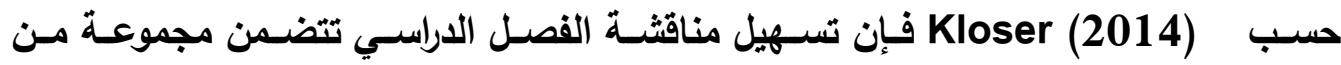
الممارسات مثل: مشـاركة الاليل والتفسيرات القائمـة على النمـاذج والحجج، وتثشجيع الطلاب على تناول أفكار الآخرين وتوضيحها وتبريرها. بالإضـافة إلى ذلك، فإن ممارسـات العلوم

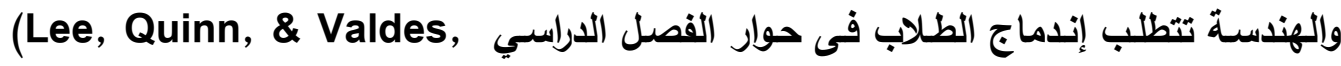
(2013, p.22) كما أن إعادة تنظيم حوار الفصل الدراسي لزيادة دور الطلاب فى الحديث

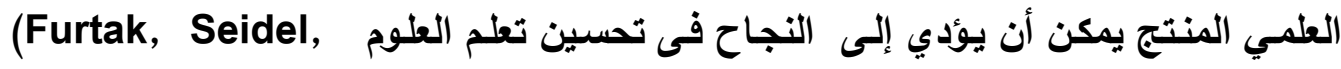
فئا يقع على عاتق المعلمين تدعيم الجدل العلمي فى (Inverson, \& Briggs, 2012) فصولهم الدراسية، وهذه النظرة تختلف جزرياً عن الممارسـة التعليمية الحالية، والتي تركز على تعلم الطلاب المفاهيم العلمية والنظريات بعيداً عن الممارسات التى تؤدي إليها. وتتضمن

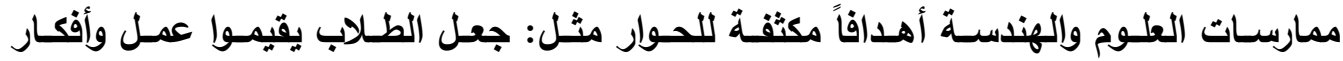
زملائهم، والتعبير عن أفكارهم الأولية عن الظواهر العلمية ومراجعتها خـلال تطور معرفتهم بهذه الظواهر (مثل: النمذجة العلمية). وتقصي أسئلتهم العلمية الخاصة (مثل: تصميم وتتفيذ التجـارب، تحليـل البيانـات وتواصـل النتائج). واستـذام الـليل بنـاء الحجـج العلميـة. ويمكن القول إن تصميم الفرص بشكل فعال للمعلمين لتعلم كيفية تعزيز الحوار الطلابي المنتج فى

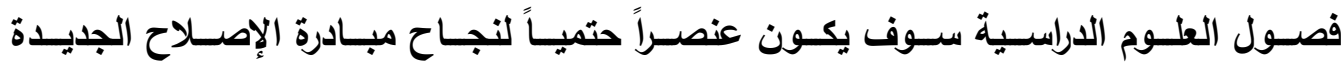

.(Kawasaki, 2015)

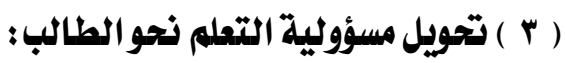

ميزة أو ملمـح رئيسي آخر لمعايير (NGSS) هو أن الطلاب يأخذون المسؤولية الكبرى

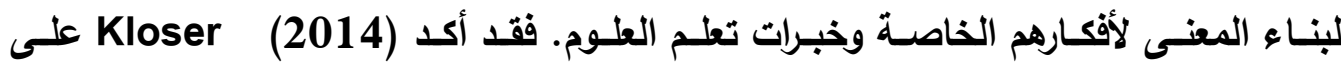

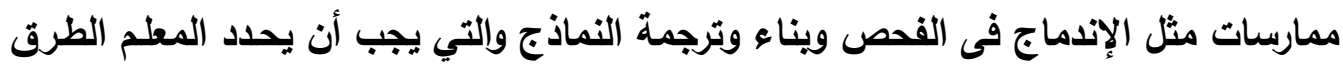


برنامج مقترح قائم على معايير العلوم للجيل القادم (NGSS) لتدريب معلمي العلوم بالمرحلة الإعدادية.

لمسـاعدة الطلاب أثناء قيـامهم بالتصميم والبناء وتخطيط الإستقصـاءات وتطوير النمـاذج.

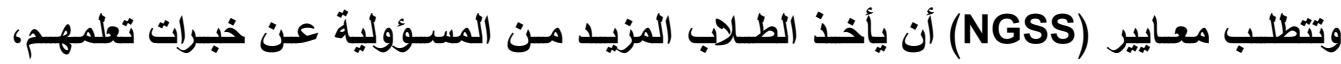

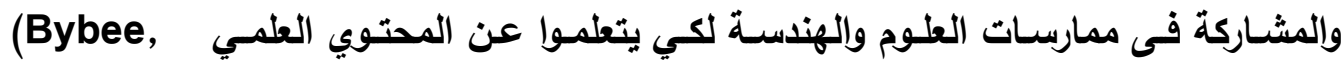
. 2011)

وقد أجرى مجموعة من الباحثين دراسـات هدفت إلى دراسـة معايير (NGSS) بصفة عامـة وكيفية تفعيل ودمـج ممارسـات (SEPs) بشكل خاص ومـن هذه الاراسـات: (Duschi \&)

Bybee, 2014; Kloser, 2014; Kawasaki, 2015; Morales, 2016) فقد أجرى (2016) Morales دراسـة حالـة كيفية مـن مرحلتين لفحص خبرة معلم العلوم بمدرسة متوسطة لنسج أبعاد (NGSS) الثلاثة بداخل وحدة موجودة هي وحدة الصحة و العقار . واسـتخدم المقـابلات الشخصية، وملاحظـات الفصل الدراسـي لكي يجمـع البيانـات المناسبة، وأوضحت النتائج أن المعلم يحتاج مزيد من الدعم لفهم ممارسـات معايير NGSS من خلال تدعيم التعلم ثلاثي الأبعاد. وأوضحت نتائج دراسة (2014) Kloser أن ممارسة المعلم للتدريس يمكن أن تؤثثر على تحصيل الطالب وميوله. وحدد هيئة أساسية من الممارسات التدريسية وإلتي ريما تكون أحد مفاتيح تحسين التربية العلمية. وقد استخدم طريقة دلفاي Delphi ، حيث استخدم ثلاثة دورات من دلفاي والتي تكونت من (1ه) خبير من معلمي العلوم ومن أعضاء هيئة التدريس بالجامعة لتحديد هيئة محورية من ممارسات تدريس العلوم. وقد أكدت الدراسة على أهمية إشرالك الطلاب فى التحقيقات وتسهيل الحوار بالفصل الدراسي وتطوير لغة مشتركة لتريس العلوم مع التأكيد على التقويم المستمر . ويمكن القول إن التحول من التحكم من المعلم إلى التى

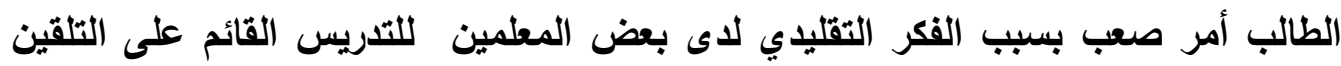

من المعلم للطالب (Taylor \& Booth, 2015). • استراتيجيات تفعيل دمج ممارسات العلوم والهندسة أثناء تلدريس العلوم: أولاً : جعل أهداف معايير (NGSS) وأهداف المعلمين واضحة : ويرى (2015) Kawasaki أنه يجب تصميم الفرص أثناء جلسـات النمو المهني أثناء استخدام معايير (NGSS) للمعلمين لجعل هذه الأهداف واضحة، ويعد ذلك تقديم فرص لهم لانعكاس ذلك على دروسهم وتوضيح كيفية تعديلها لتتماشسي مـع هذه الأهداف، نظراً لتأثيرها 
برنامج مقترح قائم على معايير العلوم للجيل القادم (NGSS) لتدريب معلمي العلوم بالمرحلة الإعدادية.

على التصميم التدريسي. وتمثل جلسـات النمو المهني بيئة خصبة لاستكشاف الاستراتيجيات

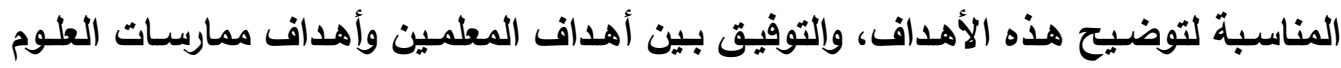
والهندسة فى معايير (NGSS) وحينئذ تصميم التدريس المناسب. ثانياً : انفتاح الأنشطة التدريسية الحالية : إن تعديل المعلمين لاروسهم لتكون مفتوحة النهاية بشكل أكبر (مثل تعديل التجارب والأنشطة عن طريق عدم تقديم إجراءات أو توجيهات وتزويد الطلاب بفرص لأخذ مزيد من من منه

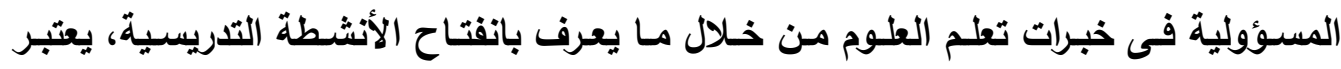
السبيل لهم للوصول إلى طرق جاذبة لتعديل تدريسهم بالفصل الدراسي التلبية متطلبات معايير (NGSS)

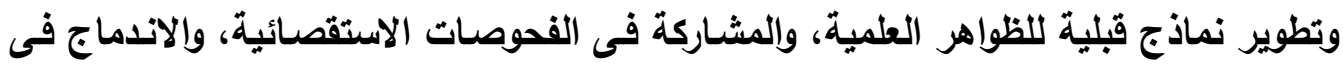
نقد الأقران والتساؤل حول المحتوى العلمي. وقد وضع (2013) McNeil and Kinight إطاراً لهذه الاستراتيجية والذي أطلق عليه أنشطة الانفتاح (Opening Up)، حيث جعل الأنشطة مفتوحة النهاية بشكل كبير

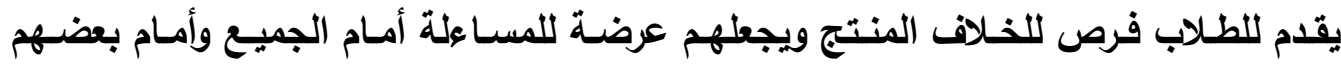
البعض. ويمكن القول إن أنثطة الانقتـاح هـي الطريقـة السـهلة والمنتجـة للمعلمين للامج

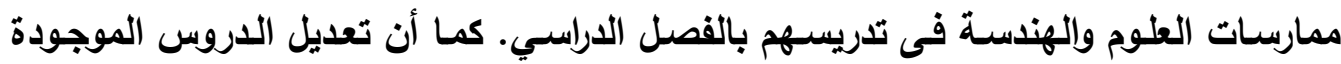
(وليس اعادة تصميم الدروس أو محاولـة استخدام منهج جديـ بشكل كامـل ) لتكون أكثر انفتاحاً قد يكون بديلاً صالحاً لتطوير و/ أو تبني منهج جليد. كما أن أن تعديل الدروس الحالية

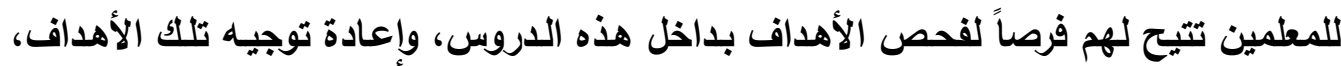
إذا لزم الأمـر، لمواعمتها مـع أهداف (NGSS)، ومـن ثم تحسين استراتيجياتهم التدريسية لتحقيق تلك الأهداف. ويمكن مـن خـلال جلسـات النمـو المهنـي أن تقدم فرص تدعيميـة للمعلمين لفحص خططهم التدريسية وخطط دروس زملائهم، وتحديد الفراغات التي يمكن أن يحدث بها الانفتاح، وتمشيها مع أهداف ممارسات العلوم والهندسة (Kawasaki, 2015). ثالثاً : التفلية الراجمة القابلة للتنفيذ في الوقت المناسب : تعمل التظذية الراجعة للمعلم على تدعيم تحسين التدريس بالفصل الدراسي. فتقديم تغذية راجعة عالية الجودة هي سمة مهمة فى برامج إعداد المعلم مثل المجلس القومي لجودة 
برنامج مقترح قائم على معايير العلوم للجيل القادم (NGSS) لتدريب معلمي العلوم بالمرحلة الإعدادية

التدريس (National Council on Teaching Quality NCTQ, 2011 ) ومجلس اعتمـاد إعداد المعلم Council for Accreditation of Educator Preparation (CAEP, 2013) ( حيث تعمل التغذيـة الراجعة على مسـاعدة المعلمين على التفكير فى (التى كيفية تنقيح دروسهم، فالتغذية الراجعة مهمة فى تدعيم التعلم عندما تكون قابلة للتنفيذ وفي

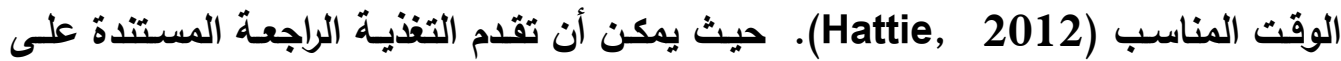

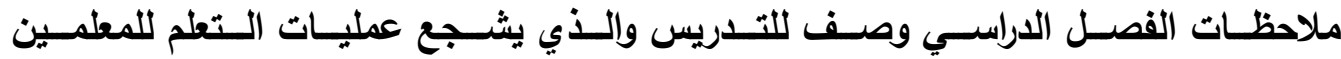
(Khachatryan, 2015). ويمكن فى هذا السياق تقديم تغذيـة راجعة للمعلمين لتنقيح دروسـهم بمـا يتماشـي مـع معـايير (NGSS) وتحقيق أهدافها. وهذه التغذيـة الراجعة بمـا تتضمنه من تعليقات يمكن أن يدمجها المعلم فوراً فى الفصل الدراسي. ويمكن أن تتم هذه اهن

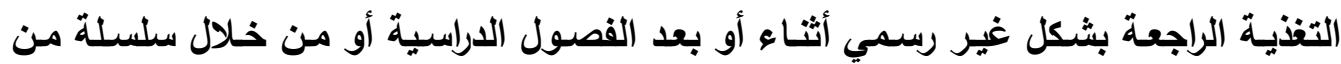
تبادل البريد الإكتروني، ومن ثم يمكن أن تدعم دمـج ممارسـات العلوم وإلهندسة في الفصل الدراسي العادي(Kawasaki, 2015). وتمثل هذه الإستراتيجيات الثُلاث وسيلة لتدعيم

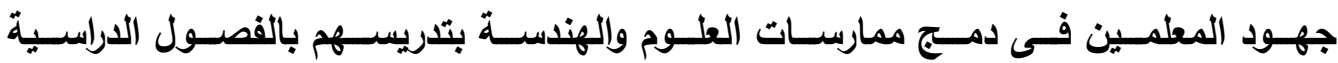
.(Kawasaki, 2015) وقد أجرى (2015 (2ablan دراسة هدفت إلى تحديد مدى تأثير برنـامج فى النمو المهني الخاص بموضوع معين في التأثير على قدرة معلمي العلوم على تصميم وإستخدام دروس العلوم والتى تدمج ممارسات العلوم فى القرن الحادي والعشرين فى الأردن. وأوضحت النتائج أن المعلمين استفادوا من مشـاركتهم فى البرنـامج وكانوا قادرين بشكل أفضل على تخطيط وإستخدام خططهم التدريسية القائمسة على الاستقصـاء واستخد/مها في الفصل الدراسـي. وهدفت دراسـة (2016) إلـى تقديم روئية مقترحسة لتدريس العلوم فى الأردن فى ضوء معايير (NGSS) وأثشارت إلى أن المناهج يجب أن تركز على ريطها بالرياضيات، وترجمة وتحليل البيانـات. ويمكن القول إنـه من خلال مراجعة الأدبيـات فإن الأدلة التجريبيـة تـدعم التأثيرات الإيجابيـة الناتجـة عن تطبيق (Kloser, 2014; Duschi \& Bybee, أثناء تدريس العلوم [SEPs] ممارسات 
برنامج مقترح قائم على معايير العلوم للجيل القادم (NGSS) لتدريب معلمي العلوم بالمرحلة الإعدادية.

ولا تزال الدراسـات التي أجريت على المستوى العربي والمصري قليلة في هذا المجال. فقد أجرت Malkawy \& Rababah (2018) دراسة لتحديد مدى استخدام معلمـي العلـوم بالصـف الثـاني عشـر الثـانوي بـالأردن لممارسـات العلـوم والهندسـة، وأوضحت نتائج الدراسـة وجود مستوى متوسط لهذه الممارسـات للى المعلمين، كمـا وجدت فروق بين المعلمين الأكور والإنـاث لصالح الإناث في درجة استخدامهم لهذه

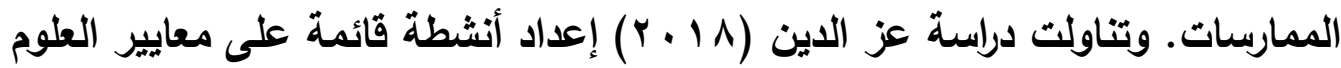
للجيل القادم لتنمية الممارسات العلمية والهندسية والتفكير الناقد والميول العلمية في

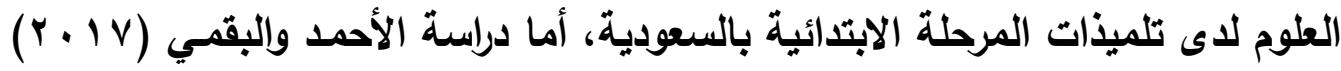
فقد تناولت تحليل محتوى كتب الفيزياء في المملكة العربية السعودية في ضوء معايير

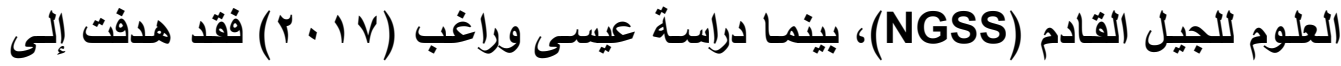
تقديم روئة مقترحة لتطوير التربية الجيولوجية عبر المراحل الدراسية المختلفة من

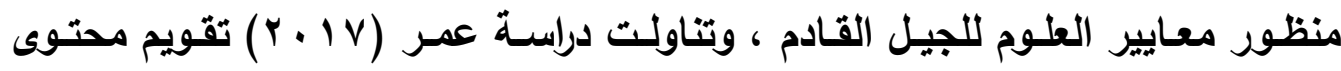
منـاهج علوم الحياة بالمرحلة الثانويـة في ضوء معايير العلوم للجيل القادم، وهدفت

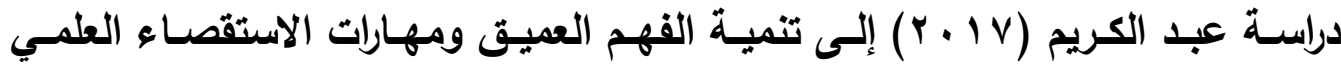
والجدل العلمي للى معلمي العلوم في المرحلة الابتدائية باستخدام برنـامج قائم على معسيير العلـوم للجيـل التـالي. ونـلاحظ مـن خـلال استعراض الدراسـات السـابقة التـي أجريـت سـواء على المستوى الـدولى أو على المستوى العريسي والمحلى أنسه لا توجد دراسة حاولت تحديد درجة استخدام معلمي العلوم في مصر وتطبيق طلابهم لممارسـات العلوم والهندسة وأيضاً لبناء برنامج تدريبي لمعلمي العلوم لتدعيم استخدام ممارسـات العلوم والهندة بمعايير العلوم للجيل القادم وذلك على حد علم الباحث وهنـا يتضح الاختلاف بين البحث الحالى والدراسات السابقة. وقد أستفاد الباحث من دراسـة الأدبيات والدراسـات والمشروعات السـابقة في البحث الحالي. حيث استخدم الباحث الإطار النظري عند إعداد الاستبيانات الخاصـة بممارسـات العلوم والهندسـة (SEPs) بمعايير العلوم العلوم للجيل القـادم (NGSS) 
سواء بالنسبة لمعلمي العلوم أو بالنسبة للطلاب. كما ساعد الإطار النظري للبحث على

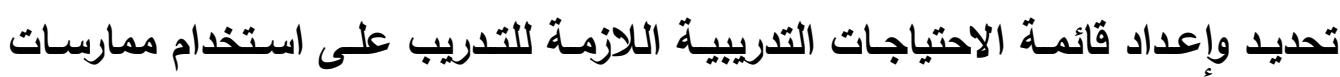
العلوم والهندسة. كما كان للاراسة النظرية لمعايير العلوم للجيل القادم دور أساسي في بناء البرنامج المقترح لتدريب معلمى العلوم على استخدام ممارسـات العلوم والهندسة أثناء تدريس العلوم ومساعدة طلابهم على تطبيقها أثناء حصص العلوم. وفيما يأتي يتناول الباحث إجراءات البحث.

\section{إجراءات البحث}

\section{: Context and Participants تحليل سياق البحث والمشاركين}

تضمن مجتمع البحث الحالي جميع معلمي العلوم بالمدارس الإعدادية " بأربعة إدارات تعليمية فقط " بمحافظة القاهرة الكبرى وهي: الزيتون، مدينة نصر، الخانكة، العبور. وقد تم اختيار مجموعة عشوائية بسيطة مكونة من ( • ب ) معلماً ومعلمة من معلمي العلوم الأين يشتركون في صفة أساسية وهي تدريس منـاهج العلوم بالمرحلة

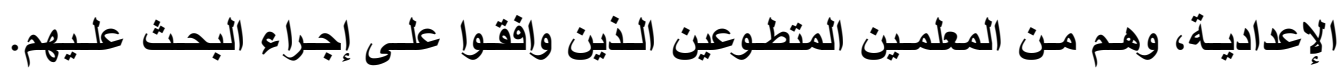
ويوضتح جدول (1) توزيع مجموعة البحث على المدارس المختلفة والإدارات التعليمية وعدد المعلمين في كل مدرسة. جدول ( 1 ) توزيع مجموعة البحث من معلمي العلوم بالمدارس والإدارات التعليمية المختلفة وعددهم

\begin{tabular}{|c|c|c|c|}
\hline عدد المعلمين & الإدارة التعليمية & أسم المدرسة & م \\
\hline$\varepsilon$ & إدارة الزيتون التعليمية & كلية السلام الرسمية بنات & 1 \\
\hline ○ & إدارة الزيتون التعليمية & الجليل الرسمية لغات & r \\
\hline 7 & إدارة الخانكة التعليمية & الخانكة الإعدادية بنات (1) & $r$ \\
\hline$\varepsilon$ & إدارة مدينة نصر التطليمية & القاهرة الدولية بمدينة نصر & $\varepsilon$ \\
\hline ○ & إدارة مدينة نصر التعليميّة & هارفارد الدولية بمدينة نصر & ○ \\
\hline 1 & إدارة العبور التعليمية & منارة أبوزيد بالعبور & 7 \\
\hline
\end{tabular}

\section{Data Sources مصادر البيانات}

تم جمع البيانات في هذا البحث من خلال استخدام ثلاثة مصادر، وهي: استبيان ممارسات العلوم والهندسة (SEPs) لمعلمي العلوم. استبيان ممارسات العلوم واللهنسة (SEPs) للطلاب من وجهة نظر معلميهم. 
برنامج مقترح قائم على معايير العلوم للجيل القادم (NGSS) لتدريب معلمي العلوم بالمرحلة الإعدادية. .

• استبيان الاحتياجـات التدريبية لممارسـات العلوم واللهندسة (SEPs) لمعلمي

العلوم.

أولاً : تحليد ملدى استخدام معلمهو العلوم بـالمر حلة الإعداديـة لممارسـات العلوم والهندسلة ( SEPS ) بمعايير ( NGSS ) أثناء تدريس العلوم: للإجابة على السؤال الأول من أسئلة البحث والذي ينص على: مـا مدى استخدام معلمو

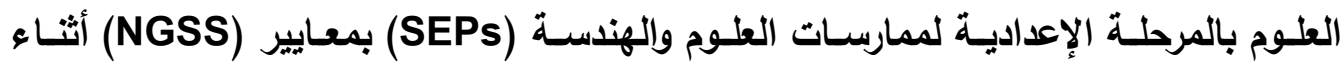
تدريس العلوم ؟ قام الباحث بالإجراءات التالية: ( 1 ) إعداد استبيان ممارسات العلوم والهندسة (SEPS) لمعلمي العلومץ : قام الباحث بترجمة واستخدام الاستبيان الذي أعده (2015 (Kawasaki ، وذلتك من خلال اتبـاع الإجراءات المحددة والموصسي بها فى دراسـة (1970) Brislin، والتي استخدمت لترجمة الأدوات إلى اللغة العربية، وهي كما يلي: (1) ترجمة الأداة الأصلية باللغة الإنجليزية إلى العربية.

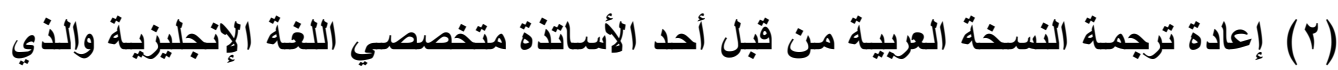
ليس لايه معرفة بالنسخة الأصلية. (r) حينئذ تم مقارنة ثلاثة إصدارات: النسخة الأصلية (2015) Kawasaki)، والنسخة التى ماصلي تم ترجمتها من قبل الباحث، ونسخة أستاذ اللغة الإنجليزية من العربية إلى الإنجليزية.

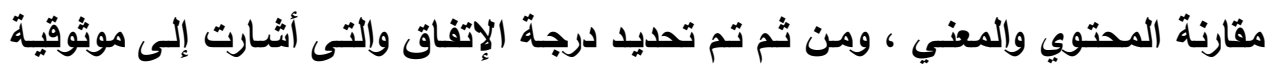
الترجمة للأداة .

وتكونت النسخة النهائية من الاستبيان من (^) بنود لمعلمي العلوم تتطابق مـع الثماني

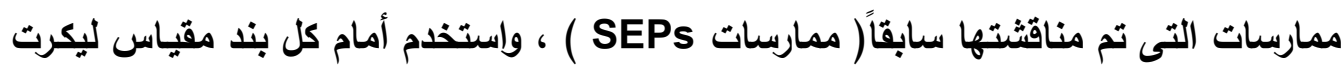
Likert

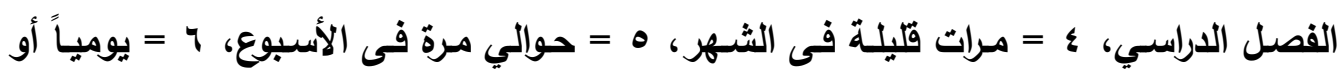
تقريباً يومياً).

r ملحق ( r ) استبيان ممارسات العلوم والهندسة (SEPs) لمعلمي العلوم في صورته النهائية. 
برنامج مقترح قائم على معايير العلوم للجيل القادم (NGSS) لتدريب معلمي العلوم بالمرحلة الإعدادية

قام الباحث بعرض الاستبيان على مجموعة من خبراء التربية العلمية، وذلك لتحديد مدى

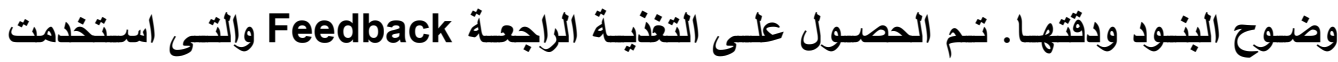
لتوضيح بعض الكلمات والبنود وتم إجراء بعض التعديلات في ضوء اقتراحات السادة الخبراء. قام الباحث بتطبيق الاستبيان على ( • 1 ) معلمين من غير مجموعة البحث وذلك لحساب معامـل ثبات الاستبيان باسـتخدام برنـامج (SPSS) للتحليل الإحصـائي وتـم حســاب معامـل الفاكرونباخ The Cronbach Alpha ويلغت قيمة معامل الثبات للاستبيان (0.83) ، والذي يعتبر قيمة مناسبة لمعامل الثبات لمثل هذا النوع من الأدوات (Odeh, 2010).

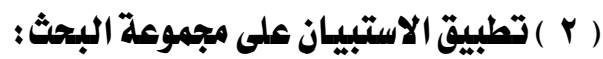
قام الباحث بتوزيع الاستبيان على مجموعة معلمي العلوم في في بداية الفصل الدراسي

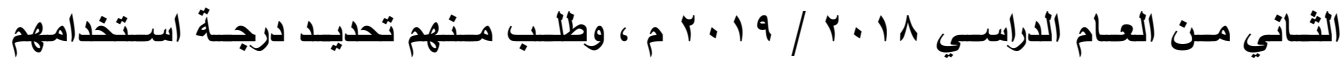
لممارسات العلوم والهندسة أثناء تدريسهم العلوم بالفصل الدراسي وتم استخراج النتائج. ثانياً : تحديلد ملى تطبيق طلاب المر حلة الإعداديـة لممارسـات العلوم والهندسة ( SEPS ) بمعايير ( أثثاء حصص العلوم : (NGSS ) للإجابة على السؤال الثاني من أسئلة البحث والذي ينص على: مـا مدى تطبيق طـلاب المرحلـة الإعداديـة لممارسـات العلـوم والهندسـة (SEPs) بمعـايير (NGSS) أثنـاء حصص العلوم ؟ قام الباحث بالإجراءات التالية:

( 1 ) إعداد استبييان ملى تطبيق ممارسات العلوم والهندسة ( SEPS ) من قبل الطلاب ب ؛

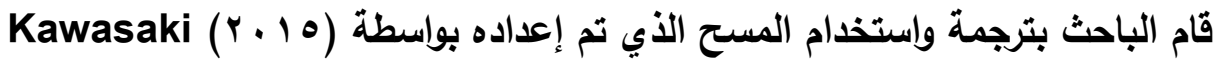
وذلك لتحديد مدى تطبيق طلاب المرحلة الإعدادية لممارسات العلوم والهندسة (SEPs) بمعايير (NGS) أثناء حصص العلوم في ضوء التقرير الذاتي لمعلميهم، وتكونت النسخة النهائية من الاستبيان من (7 (1) بند تعكس ممارسات العلوم والهندسة بداخل فصول العلوم،

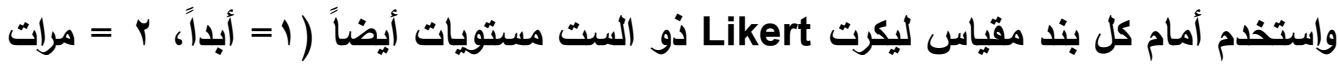

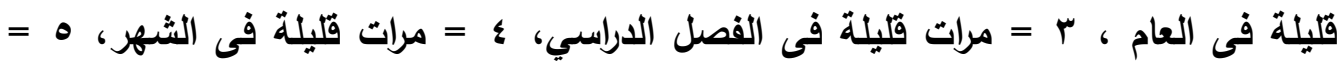

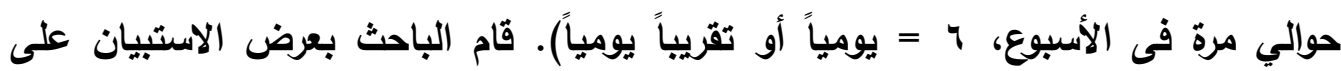

" ملحق ( " ) استبيان مدى تطبيق ممارسات العلوم و الهندسة (SEPs) من قبل الطلاب في صورته النهائية. 
برنامج مقترح قائم على معايير العلوم للجيل القادم (NGSS) لتدريب معلمي العلوم بالمرحلة الإعدادية

مجموعة من خبراء التربية العلمية، وذلك لتحديد مدى وضوح البنود ودقتها، وتم إجراء بعض

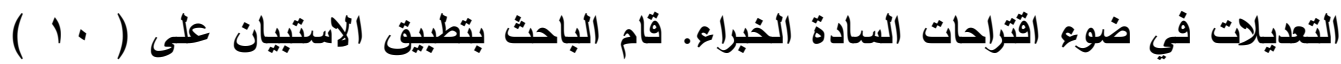
معلمين من غير مجموعة البحث وذلك لحساب معامل ثبات الاستبيان باستخدام برنامج The Cronbach Alpha للتحليل الإحصائي ونم حساب معامل الفاكرونباخ (SPSS) ويلغت قيمة معامل الثبات للاستبيان (r (1.)، والذي يعتبر قيمة مناسبة لمعامل الثبات - (Odeh, 2010) ( ) ) تطبيق الاستبيان على مجموعة البحث : قام الباحث بتوزيع الاستبيان على مجموعة معلمي العلوم في بداية الفصل الدراسي

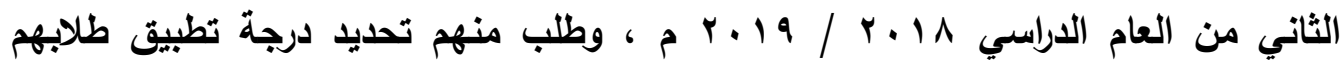
لممارسات العلوم والهندسة أثناء حصص العلوم وتم أستخراج النتائج. ثالثاً: تحلديد الاحتياجات التدريبية لمعلمي العلوم بـالمرحلة الإعدادية في ضوء ممارسات العلوم والهنلسة ( SEPS) بمعايير (NGSS) ) للإجابة على السؤال الثالث من أسئلة البحث والذي ينص على: ما الاحتياجات التدريبية لمعلمي العلوم بالمرحلة الإعدادية في ضوء ممارسات العلوم والهندسة (SEPs) بمعايير (NGSS) ؟ قام الباحث بالخطوات التالية: ( 1 ) بناء استبيان تحليد الاحتياجات التدربيية في ممارسات العلوم والهندسة (SEPs) ؛ قام الباحث ببناء استبيان الاحتياجات التدريبية في ممارسات العلوم والهندسة وذلك تمهيداً لبناء البرنامج التدريبي المقترح لمعلمي العلوم، وقد سارت عملية بناء الاستبيان في

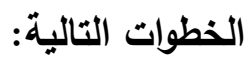

( أ ) تحليد الهدف من الاستبيان: هدف الاستبيان إلى تحديد الاحتياجات التدريبية اللازمة لمعلمي العلوم لتدعيم استخدامهم لممارسات العلوم والتهنسة (SEPs) بمعايير العلوم للجيل

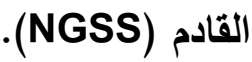
( ب ) إعداد الصورة الأولية للاستبيان: اعتمد الباحث في تصميم الاستبيان على مجموعة من المصادر المختلفة مثل : (Kawasaki, 2015; Malkawy and دراسة البحوث والدراسات السابقة مثل دراسات Rababah, 2018) 
برنامج مقترح قائم على معايير العلوم للجيل القادم (NGSS) لتدريب معلمي العلوم بالمرحلة الإعدادية.

• دراسة الأدبيات والمشروعات السابقة مثل: الإطار المقترح للتربية العلمية بالولايات المتحدة الأمريكية (NRC, 2012)، ومعايير العلوم للجيل القادم (NGSS, 2013). ومن خلال هذه الدراسة للاراسات والمشروعات السابقة وتحليلها تم التوصل إلى قائمة مبلئية بالاحتياجات التدريبية اللازمة لمعلمي العلوم في ممارسات العلوم والهندسة (SEPs) ممارسات العلوم واللهندسة.

( ) ) تحليلد صدق الاستبيان: قام الباحث بعرض الاستبيان على مجموعة من السادة الخبراء في التربية العلمية لتحديد صدق الاستبيان والتأكد من انتماء العبارات لمحاورها، ودقة الصياغة للعبارات، وكذا إضافة أو حذف أي من العبارات أو تعديلها. وقد تمثلت التعديلات

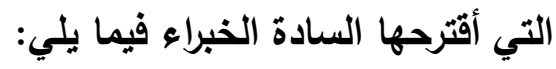
إضافة عبارة في بداية القائمة " أرجو تحديد درجة حاجتك للتدريب على الممارسات التالية لكي تصبح قادر على تنميتها لاى طلابك بشكل كبير " .

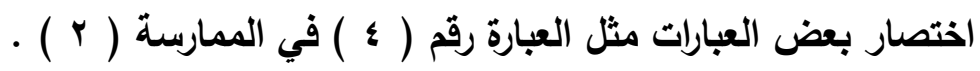
تعديل صياغة بعض العبارات مثل عبارة ( V ) في الممارسة ( 1 ( ) ) ، حيث كانت العبارة : بناء أداة أو ( جهاز ) أو استخدام حل تصميم ، وتم تعديل العبارة لتصبح : تصميم أداة أو ( جهاز) أو استخدام حل تصميم.

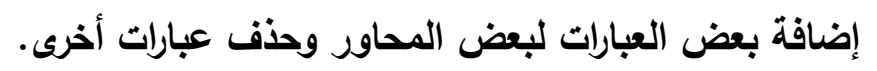
( د ) الصورة النهائية للاستبيانء: في ضوء التعديلات التي اقترحها السادة الخبراء تم إعداد الصورة النهائية للاستبيان والتي تكونت من ( ؟ ^ ) عبارة مقسمة على ( 1 ) محاور. ( ه ) حساب ثبات الاستبيان: قام الباحث بتطبيق استبيان الاحتياجات التدريبية لممارسات العلوم والهنذسة على (• 1) من معلمي العلوم من غير مجموعة البحث، وتم حساب معامل ثبات الاستبيان باستخدام برنامج (SPSS) الإحصائي، وذلك للاستبيان ككل وأيضاً لكل محور مئم

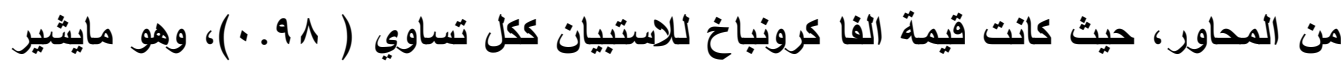

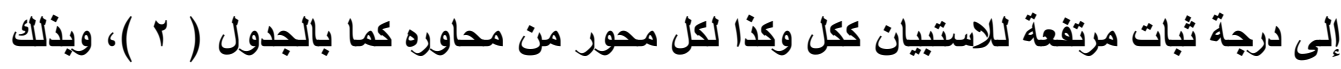
يكون قد تم التأكد من صلاحية الاستبيان للتطبيق على معلمي العلوم.

" ملحق ( ؛ ) استبيان الاحتياجات التدريبية في ممارسات العلوم والهندسة (SEPs) لمعلمي العلوم. 
برنامج مقترح قائم على معايير العلوم للجيل القادم (NGSS) لتدريب معلمي العلوم بالمرحلة الإعدادية ... جدول ( r ) توزيع الاحتياجات التدريبية لممارسات العلوم والهندسة وعددها ومعامل الثبات لكل محور

\begin{tabular}{|c|c|c|c|}
\hline معامل ثبات الفا كرونباخ & عدد العبارات & محور الاحتياجات التدريبية & م \\
\hline$\cdot . \wedge \neg$ & 11 & ممارسةة (1 ) & 1 \\
\hline $.9 r$ & 1. & ممارسة ( Y ) & $r$ \\
\hline .97 & $\Lambda$ & ممارسة (r) & $\mu$ \\
\hline $.9 V$ & ir & ممارسة ( ع ) & $\varepsilon$ \\
\hline $.9 r$ & 11 & ممارسة ( • ) & $\bullet$ \\
\hline .94 & 11 & ممارسة ( 7 ) & 7 \\
\hline $.9 V$ & Ir & ممارسة (V) & V \\
\hline. .94 & 1. & ممارسة ( ) م ) & $\Lambda$ \\
\hline .91 & ل 1 ع عبارة & الاستبيان ككل & 9 \\
\hline
\end{tabular}

( r ) تطبيق استبيان الاحتياجات التدريبية:

قام الباحث بطبيق استبيان الاحتياجاث التديبية على مجموعة البحث والمكونة من

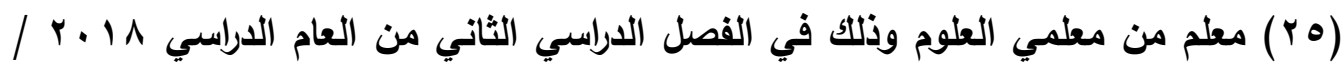
19 • P م ، ثم قام باستخراج النتائج وتحليلها.

\section{نتائج البحث}

أولاً : تتائج تطبيق استبيان ممارسيات العلوم والهندسة (SEPS ) لمعلمي العلوم:

Self-Report تم استخدام المتوسطات والإنحرافات المعيارية لحساب التقرير الذاتي لاستخدام الـ SEPs بين مجموعة معلمي العلوم لكي يتم الإجابة على السؤال البحثي الأول: ما مدى استخدام معلمو العلوم بالمرحلة الإعدادية لممارسات العلوم واللهندة (SEPs) بمعاييز (NGSS أثناء تدريس العلوم ؟ كما قام الباحث بتحديا فئات التكرار باستخدام التدريج التسبي. وتم حساب درجات التوافر لكي يتم تحديد الفئات (المرتفعة، المتوسطة، المنخفضة)، وتم تحديد ذلك باستخدام المعادلة التالية:

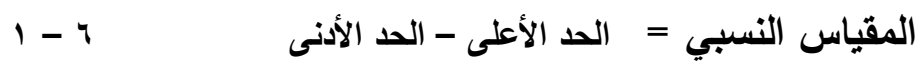

$1.7 \mathrm{~V}=$

\section{الفئات}

وتم إضافة هذه القيمة إلى الحد الأدنى للارجة لتحديد حدود كل فئة Malkawy )

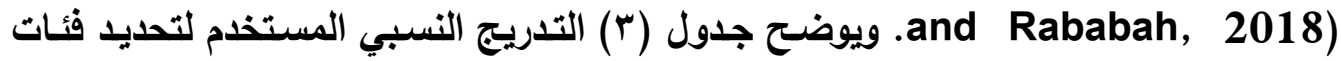


برنامج مقترح قائم على معايير العلوم للجيل القادم (NGSS) لتدريب معلمي العلوم بالمرحلة الإعدادية

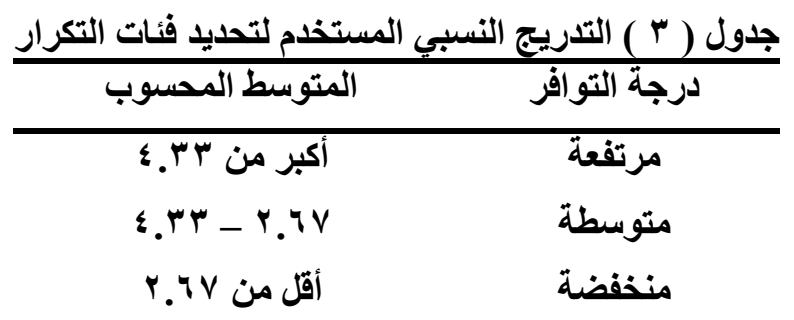

تـم اسـتخدام برنـامج SPSS لتحليـل البيانـات مـن نتـائج تطبيـق الاسـتبيان على

مجموعة البحث. ويوضح جدول ( ع ) ) هذه التتائج.

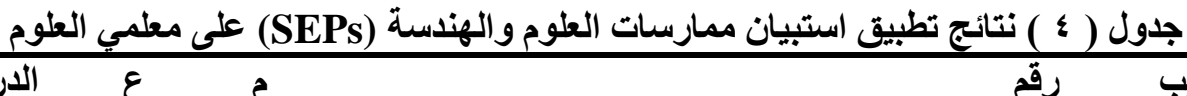

\begin{tabular}{|c|c|c|c|c|c|}
\hline الدارجة & $\varepsilon$ & p & ممارسات العلوم والهندسة لمعلمي العلوم & 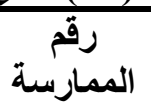 & الممارسيبة \\
\hline متوسطة &. $.9 r$ & $\varepsilon . Y \varepsilon$ & تناقش الطلاب في الإجراءات المناسبة & 8 & 1 \\
\hline 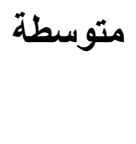 & $1.7 \cdot$ & r.9r & 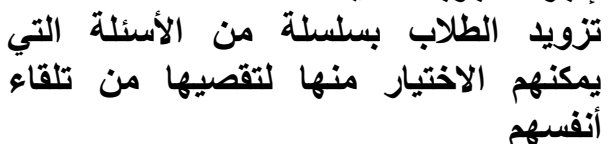 & 5 & 2 \\
\hline متوسطة &.$\vee \wedge$ & $r . \wedge \wedge$ & ترجمة البياتات & 3 & 3 \\
\hline متوسطة & I.Y & r.7. & ? أو رفضهم & 7 & 4 \\
\hline متوسطة & 1.11 & r.rr & التش ستخد رسم بياني، جدول، أو مخطط أثناء & 2 & 5 \\
\hline 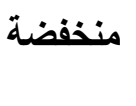 & .90 & r. & تلطب قدموه الطلاب تفسير أو تبريز ادعاء & $\mathbf{1}$ & 6 \\
\hline 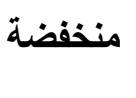 & I.Y & r.乏. & في تقريس درس حوتبر أو مقالية عتمية النتائج العلمية & 4 & 7 \\
\hline 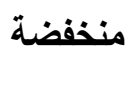 & 0.88 & 2.04 & تلبيانات الكمية عن ترجمة الإحصاءات أو & 6 & 8 \\
\hline
\end{tabular}

يتضح من الجدول ما يلي:

1. النتيجة العامة لاستخدام معلمي العلوم لممارسـات العلوم والهندسة (SEPs) هي بلرجة

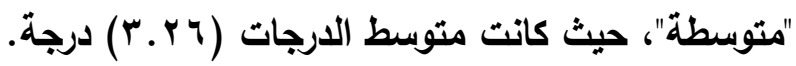

r. حصلت ثُلاث ممارسـات على درجـة " منخفضـة " في الاستخدام مـن قبل معلمي العلوم 
برنامج مقترح قائم على معايير العلوم للجيل القادم (NGSS) لتدريب معلمي العلوم بالمرحلة الإعدادية ...

ممارسة ( 1 ) وترتيبها ( 1 ) ) بين الممارسات وهي " تطلب من الطلاب تفسير أو تبرير

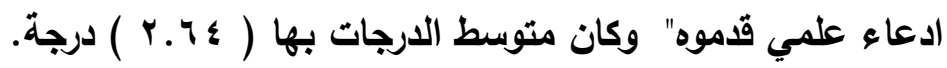

ممارسـة ( ع ) وترتيبها ( V ) ) بين الممارسـات وهـي" تـريس درس حول كيفية كتابـة

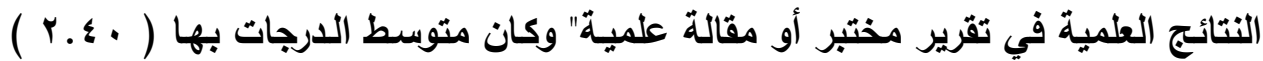
درجة.

ممارسة ( 1 ) وترتيبها ( 1 ) ) والأخيرة بين الممارسات وهي" تلدريس درس عن ترجمة

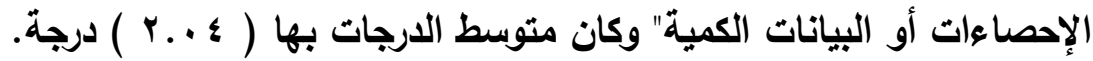

ثانياً : نتائج تطبيق استبيان ممارسات العلوم والهندسة SEPs للطلاب:

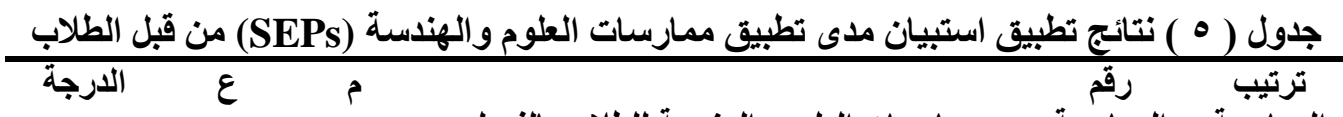
الممارسة الممارسة ممارسات العلوم والهنسة للطلاب بالفصل

\begin{tabular}{|c|c|c|c|c|c|}
\hline \multicolumn{6}{|c|}{ الارراسي } \\
\hline متوسطة & $.0 \leqslant$ & \&.Y^ & توليد أسئلتهم الخاصة حول الظواهر اليومية & 2 & 1 \\
\hline متوسطة & 1.0 & $\varepsilon$ & توليد الأسئلة عن شيء قرأوه داخل أو خارج & 11 & 2 \\
\hline متوسطة & 1.7 & r. & شغرح أفكارهم لبعضهم البعض في مجموعات & 5 & 3 \\
\hline متوسطة & $1 . . r$ & r.rt & علمية استخام المحاكاة الكمبيوترية لفهم ظاهرة & 7 & 4 \\
\hline 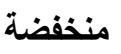 &. .01 & r.04 & ( يرسم ) الرسم البياني للبيانات العلمية & 1 & 5 \\
\hline 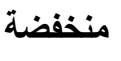 & $1.0 r$ & r.04 & إجراء تُجربة من كتابَ المعمل بشكل فردي أو & 14 & 6 \\
\hline 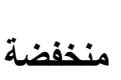 & .90 & r. $\leqslant$ & تحديد ومناقشة الاليل الذي يدعم نظرية علمية & 6 & 7 \\
\hline 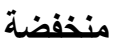 & $1 . \cdot v$ & r.. & تحليل البيانات الأولية التي جمعوها بأنفسهر & 10 & 8 \\
\hline منخفضة & 1.10 & r... & استخدام الجداول أو الرسوم البيانية لتدعيم & 12 & 9 \\
\hline 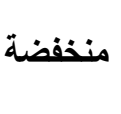 & $.7 \xi$ & 1.94 & 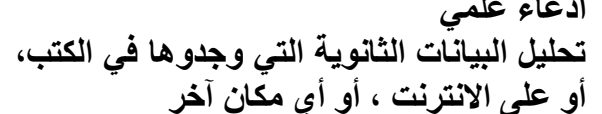 & 4 & 10 \\
\hline 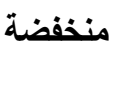 & $\cdot . \wedge 4$ & $1 . \wedge$. & المتوسط الإحصاءاءت ألبسيطة للبيانات مثل & 13 & 11 \\
\hline 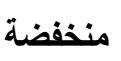 & $1 . \cdot 1$ & $1 . \wedge$. & مراجعة نموذج أوّ تفسير قاموا بعمله سابقاً & 15 & 12 \\
\hline 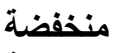 &.$\wedge \vee$ & 1.17 & تطوير تفسيراتهم الخاصة من البيانات العلمية & 9 & 13 \\
\hline 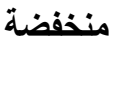 &.$v \cdot$ & 1.7 & تحول موضوع علمى الدليل لتدعيم ادعائهم الخاص & 8 & 14 \\
\hline 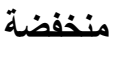 & $\cdot . \wedge 4$ & 1.07 & كتابة تقرير معملي لمشاركة النتائج من تجربة & 16 & 15 \\
\hline 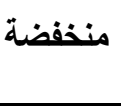 & .94 & I.rr & تشكلفيم تجاربهم الخاصة لتقصي ظاهرة علمية & 3 & 16 \\
\hline منخفضة & 0.53 & 2.42 & & علي & المج \\
\hline
\end{tabular}


يتضح من الجدول ما يلي:

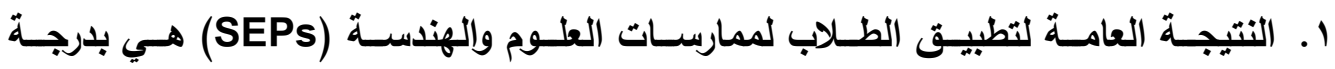

"منخفضة"، حيث كان متوسط الارجات (Y \& ـ Y) درجة.

r. حصلت ثلاث ممارسات فقط على درجة " متوسطة" من التطبيق أثناء حصص العلوم من

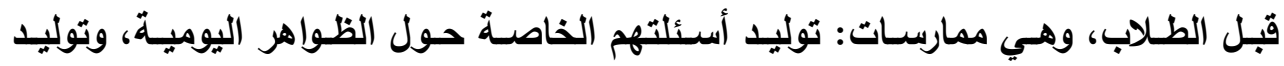

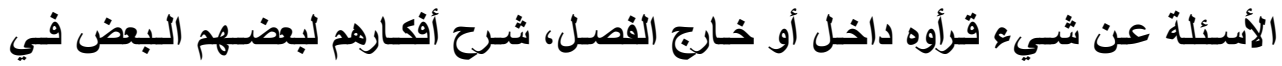
مجموعات صغيرة أو للفصل بالكامل، واستخدام المحاكاة الكمبيوترية لفهم ظاهرة علمية. r. باقي الممارسات حصلت على درجة " منخفضة " لتطبيق الطلاب لها بفصول العلوم. ـ. كـان أقل ممارسـة من الممارسـات في التطبيق من قبل الطلاب هي ممارسـة " تصميم تجاريهم الخاصة لتقصي ظاهرة علمية بشكل فردي أو جماعي" بمتوسط درجات ( r Y. I.

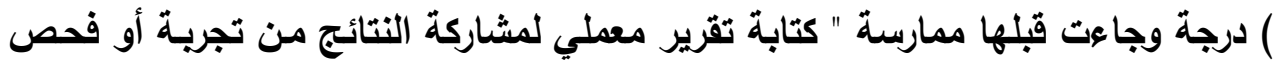
علمـي" ويمتوسط ( 1.07 ) درجـة، وفي الترتيب الثالث مـن حيث الممارسـات الأقل

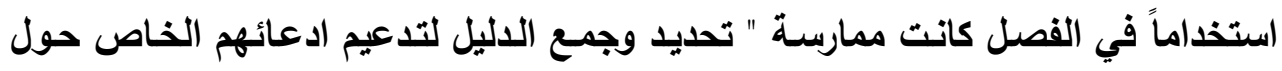

$$
\text { موضوع علمي" بمتوسط درجات ( . . 1 ) درجة . }
$$

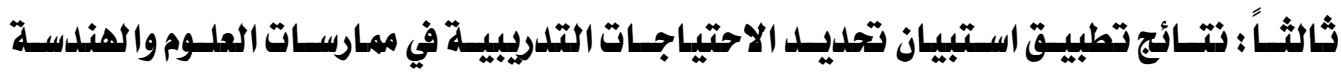
(SEPS)

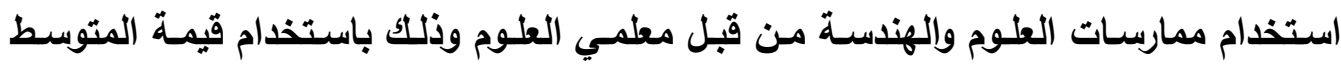
الحسابي، حيث تم حساب المقياس النسبي ووجد أنه يساوى ( ^. . . ) كما يلي:

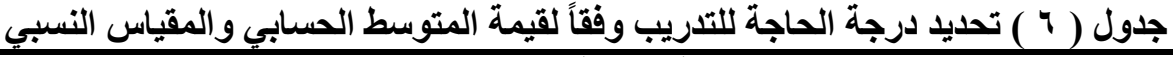

\begin{tabular}{|c|c|c|c|c|c|}
\hline \multicolumn{6}{|c|}{ درجة الحاجة للتدريب } \\
\hline ضعيفة جداً & ضعيفة & متوسطة & كبيرة & كبيرة جداً & \\
\hline $1.29-1$ & $\begin{array}{r}-1 . \Lambda . \\
r .09\end{array}$ & $\begin{array}{c}\text { - r.q. } \\
\text { r.rqq }\end{array}$ & $\begin{array}{r}-r .4 \\
\varepsilon .19\end{array}$ & $0-\varepsilon . Y$. & الحسابي \\
\hline
\end{tabular}

وفيما يلي عرضاً تفصيلياً لنتائج تطبيق الاستبيان لتحديد درجة الحاجة للتريب لكل محور

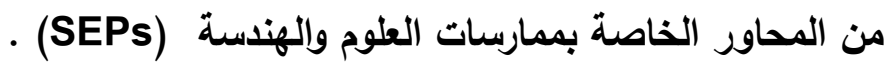


برنامج مقترح قائم على معايير العلوم للجيل القادم (NGSS) لتدريب معلمي العلوم بالمرحلة الإعدادية ...

جدول ( V ) درجة الحاجة للتدريب على استخدام ممارسة ( 1 ) طرح الأسئلة وتحديد المشكلات

\begin{tabular}{|c|c|c|c|c|}
\hline درجة الحاجة & $\varepsilon$ & 5 & الاحتياجات التدريبية & r \\
\hline كبيرة & 1.1. & $r .71$ & التمييز بين السؤال العلمي والسؤال غير العلمي & 1 \\
\hline 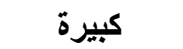 & 1.9 & $r . v r$ & طرح الأسئلة عن العالم الَّبيعي والبشري ي & r \\
\hline كبيرة & $1 . Y \varepsilon$ & 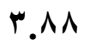 & كن الإجابة عليها تجريبياً & $r$ \\
\hline 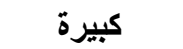 &.$\wedge 0$ & $r .71$ & إلى بناء حجة علمية & $\varepsilon$ \\
\hline كبيزة &.$\wedge 0$ & ५.^ & ول قيود ومواصفات الحلول للمشكلات & $\bullet$ \\
\hline متوسطة & 1.11 & $r . \wedge$ & تؤدي إلى ممارسات علمية إضافية & 7 \\
\hline كبيزة & $\because \wedge \varepsilon$ & $\varepsilon$. & طرح أسئلة / طرح مشكلات قابلة للاختبار & v \\
\hline كبيرة & $\because 9 \leq$ & $r . v r$ & قائمة على حب الاستطلاع الناقد & $\wedge$ \\
\hline كبيرة جداً & $\because \wedge r$ & $\varepsilon . r$. & ي استخدام استراتيجيات تدريسية تساعد الطلاب & 9 \\
\hline كبيرة & $\because 9 V$ & $\varepsilon .1 Y$ & التخطيط لمواقف تدريسية تساعد الطلاب على & 1 . \\
\hline كبيرة & $1.1 \mathrm{~V}$ & $r . \wedge \wedge$ & التذريب علي استخدام أساليب تقويم لبيان قدرة الطلاب على & 11 \\
\hline كبيرة & .77 & $r . \vee \wedge$ & المجموع الكثي & \\
\hline
\end{tabular}

يتضح من الجدول أن الحاجة للتدريب على ممارسة طرح الأسئلة وتحديد المشكلات

هي بلرجة " كبيرة"، حيث كان متوسط الدرجات (Y.V^)، كما تبين أن الحاجة إلى التدريب على استخدام استراتيجيات تدريسية تساعد الطلاب على طرح الأسئلة كاتت بدرجة " كبيرة

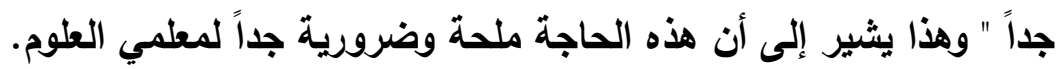

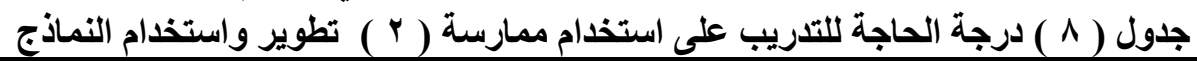

\begin{tabular}{|c|c|c|c|c|}
\hline درجة الحاجة & $\varepsilon$ & s & الاحتياجات التدريبية & r \\
\hline كبيرة & 1.41 & r.\&. & البنمية الرسوم والمخططات لتمثيل الأحداث أو النظم أو الظواهر & 1 \\
\hline كبيرة & 1.44 & $r . \wedge$ & تمثيل وشرح الظواهر بأثكال متعددة من النماذج & r \\
\hline كبيرة & 1.67 & r.7 & النموذج كتمثيل لنظام ، عملية، أو تصميم، & $r$ \\
\hline كبيرة & $1 . r \cdot$ & $\varepsilon . \varepsilon \cdot$ & الظواهذام المختلفة النماذج الإكترونية التفاعلية كأداة لفهم وتقصي & $\varepsilon$ \\
\hline كبيرة & 1.19 & r.7. & 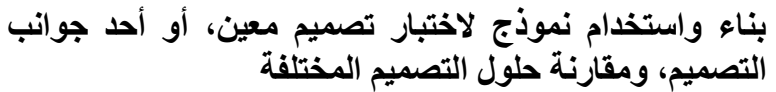 & $\bullet$ \\
\hline متوسطة & $1 . \mu V$ & r.Mr & تقويم ومراجعة النماذج & 7 \\
\hline 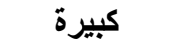 & $1 . r 0$ & r.7. & بناء نماذج قائمة على الاليل التجريبي & V \\
\hline 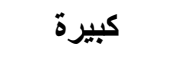 & $.9 \mathrm{~V}$ & $\varepsilon .1 r$ & ? استراتيجيات تدريسية تساعد الطلاب & $\wedge$ \\
\hline كبيرة & $1 . \mu \wedge$ & r.A. & لمواقف تدريسية تساعد الطلاب على & 9 \\
\hline كبيرة & 1.21 & $r . \leqslant \Lambda$ & تصميم واستخلى استخدم النماذج أَساليب تقويم لبيان قدرة الطلاب على & 1. \\
\hline كبيرة & $1 . r$ & $r .71$ & المجموع الكلي & \\
\hline
\end{tabular}


برنامج مقترح قائم على معايير العلوم للجيل القادم (NGSS) لتدريب معلمي العلوم بالمرحلة الإعدادية

يتضح من الجدول أن الحاجة للتدريب على تطوير واستخدام النماذج هي بلرجة "

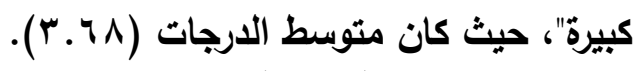

جدول ( 9 ) درجة الحاجة للتدريب على استخدام ممارسة ( r ) تخطيط وتنفيذ التحقيقات العلمية

\begin{tabular}{|c|c|c|c|c|}
\hline درجة الحاجة & $\varepsilon$ & م & الاحتياجات التدريبية & p \\
\hline كبيرة جداً & $\cdot .830$ & 4.24 & 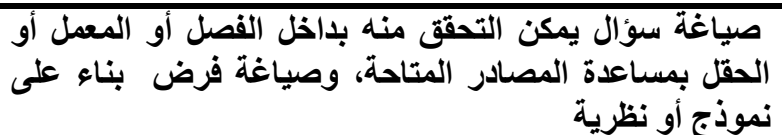 & 1 \\
\hline متوسطة & $\cdot .952$ & 3.36 & تحديد البيانات التي سيتم جمعها، وما هي الأدوات اللازمة & $r$ \\
\hline متوسطة & 1.02 & 3.28 & في الاعتبار أي حقدار البيانات المطلوبة على دقة الإنتاج قياسات موثوقة والأخذ & $r$ \\
\hline متوسطة & 1.22 & 3.20 & 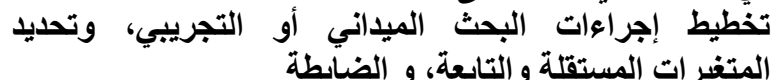 & $\varepsilon$ \\
\hline متوسطة & 1.05 & 3.12 & المربكة المحتملة أنميم التحقيق قام بضبط المتغيرات أو التأثيرات & 0 \\
\hline كبيرة & 1.31 & 3.68 & التريب على استخدام استراتيجيات تدريسية تساعد الطلاب & 7 \\
\hline كبيرة & 1.26 & 3.44 & تدريسية تنمي ممارسات تخطيط وتنفيذ & V \\
\hline كبيرة & 1.30 & 3.76 & التحقيقات العليّية تقويم لبيان قدرة الطلاب على تخطيط وتتفيذ & $\Lambda$ \\
\hline كبيرة &. $.9 r$ & $r .01$ & المجموع الكلي & \\
\hline
\end{tabular}

يتضح من الجدول أن الحاجة للتديب على تخطيط وتنقيذ التحقيقات العلمية هي بدرجة " كبيرة"، حيث كان متوبط الارجات (1. ب). 
برنامج مقترح قائم على معايير العلوم للجيل القادم (NGSS) لتدريب معلمي العلوم بالمرحلة الإعدادية

\begin{tabular}{|c|c|c|c|c|}
\hline ل & 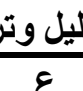 & $\varepsilon)^{\circ}$ & 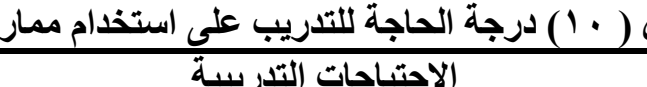 & a \\
\hline كبيرة & .96 & 3.44 & 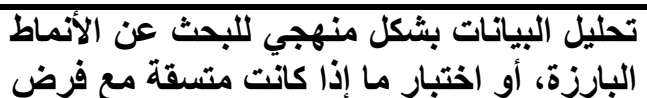 & $T$ \\
\hline
\end{tabular}

تمييز منى تكون البيانات متعارضة مع التوقعات $1.20 \quad 3.24 \quad 3$. والأخذ في الاعتبار المراجعات المنات المطلوبة في

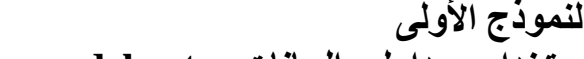

r ب البتخدام جداول البيانات Spreadsheets، والرسوم البيانية، والإحصاءات، والئات والرياضيات،

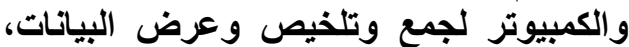

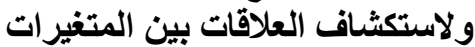

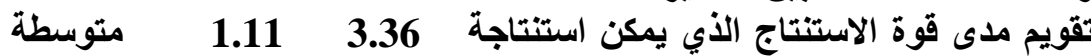

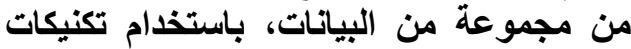

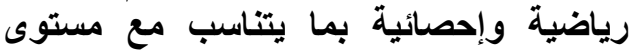
الصف الار اسي واهي

تمييز الأنماط في البيانات مثل التمييز بين $3.12 \quad 1.12 \quad 3$.

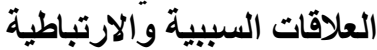

1

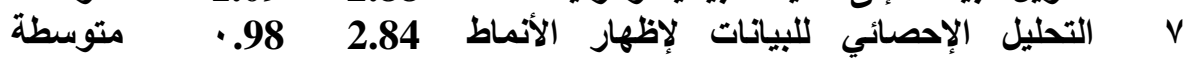

^ القدرة على تحديد مصادر الخطأ ( التجريبي $2.76 \quad 1.01 \quad$ متوسطة

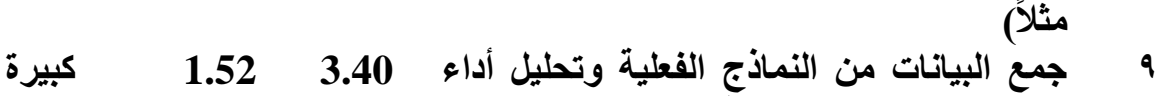

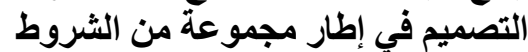

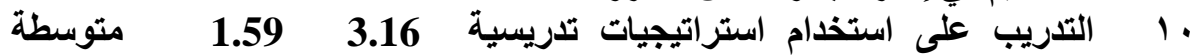
تساعد الطلاب على تحليل وترجمة البيانات التئي

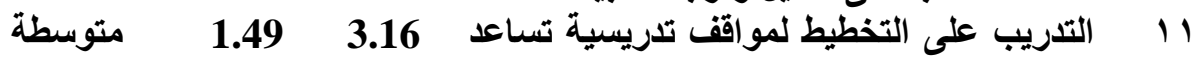

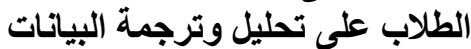

I التدريب على استخدام أساليب تقويم لبيان قدرة $\quad 3.40 \quad 1.52 \quad 3$. الطلاب على تحليل وترجمة البيانات

المجموع الكلي الطليل وترجمة البيات

يتضح من الجدول أن الحاجة للتدريب على تحليل وترجمة البيانات هي بلرجة "

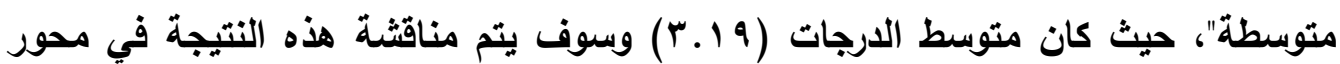
مناقشة نتائج البحث فيما يتعلق بتقدير معلمي العلوم لتحليل وترجمة البيانات وأيضاً استخدام الرياضيات والتثكير الحوسبي. 
برنامج مقترح قائم على معايير العلوم للجيل القادم (NGSS) لتدريب معلمي العلوم بالمرحلة الإعدادية.

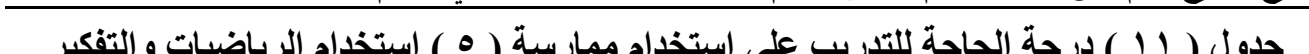

\begin{tabular}{|c|c|c|c|c|}
\hline درجة الحاجة & $\varepsilon$ & p & الاحتياجات التريبية & م \\
\hline متوسطة & 1.02 & 3.28 & 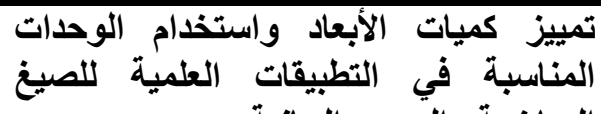 & 1 \\
\hline متوسطة & .93 & 3.28 & 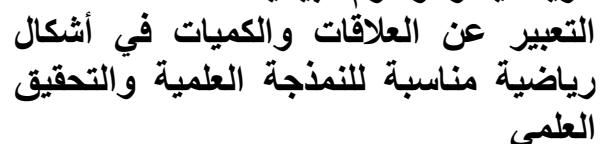 & r \\
\hline كبيرة & $• .86$ & 3.92 & 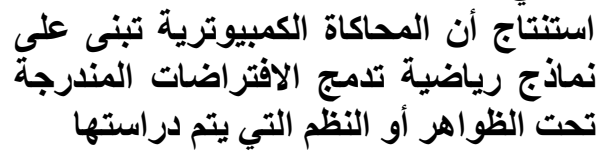 & $r$ \\
\hline كبيرة & .95 & 3.80 & 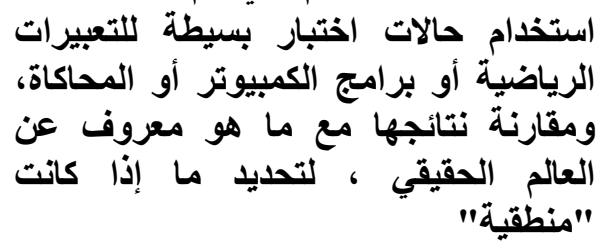 & $\varepsilon$ \\
\hline كبيرة & $\cdot .97$ & 3.72 & 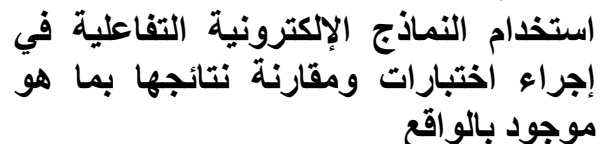 & - \\
\hline 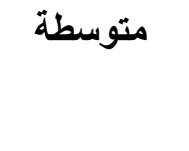 & .94 & 3.32 & 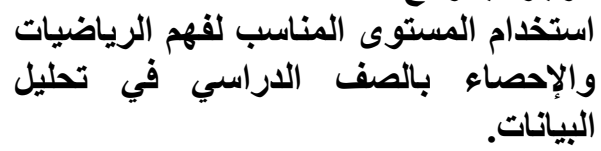 & 7 \\
\hline متوسطة & 1.18 & 3.08 & 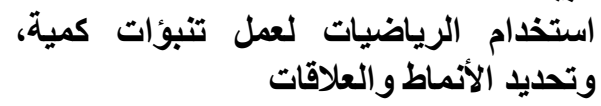 & V \\
\hline كبيرة & 1.27 & 3.72 & البياسبة) للتعامل مع مجموعة الأدوات الرقبية (الكمبيوتر، الألة & $\wedge$ \\
\hline كبيرة & 1.29 & 3.56 & تساعريب الطلاب على استخدم استخدامجيات تلدريسية & 9 \\
\hline 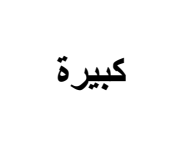 & 1.09 & 3.88 & 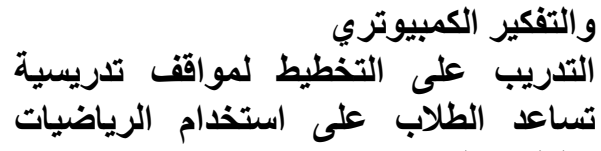 & 1. \\
\hline كبيرة & $\cdot .96$ & 3.52 & 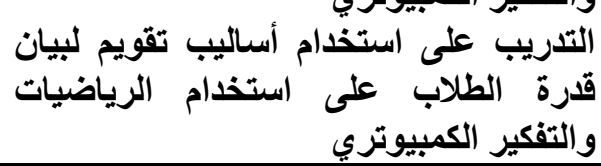 & 11 \\
\hline كبيزة &.$\wedge$. & $r .00$ & المجموع الكلي ال & \\
\hline
\end{tabular}

يتضح من الجدول أن الحاجة للتدريب على استخدام الرياضيات والتفكير الحوسبي هوهي

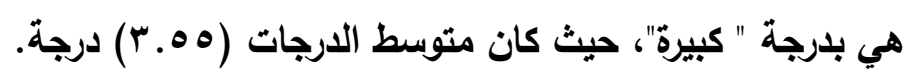


برنامج مقترح قائم على معايير العلوم للجيل القادم (NGSS) لتدريب معلمي العلوم بالمرحلة الإعدادية.

\begin{tabular}{|c|c|c|c|c|}
\hline درجة الحاجة & $\varepsilon$ & م & الاحتياجات التتريبية & \\
\hline كبيرة & 1.15 & 3.48 & 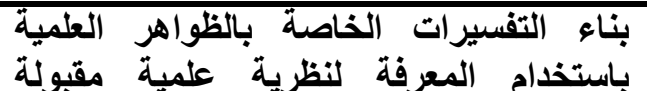 & 1 \\
\hline متوسطة & 1.01 & 3.04 & 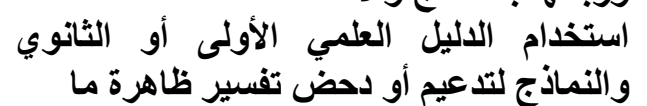 & r \\
\hline متوسطة & 1.01 & 3.04 & تلاسببة لمستوى معرفته تقليم العلمية تفسيرات سبيية & $r$ \\
\hline متوسطة & 1.03 & 3.08 & 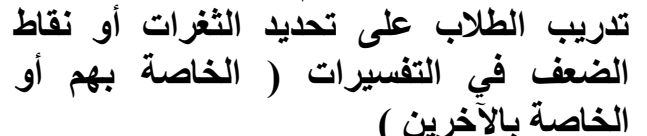 & $\varepsilon$ \\
\hline متوسطة & .86 & 3.08 & حلمية مشاكل التصميم من خلال تطبيق المعرفة & $\bullet$ \\
\hline كبيرة & .95 & 3.60 & التصرة التصميم التصاريع التصميم، والاندماج في خطول معايير & 7 \\
\hline متوسطة & 1.20 & 3.24 & تصميم أداة أو ( جهاز) أو استخدام حل & $\mathrm{v}$ \\
\hline كبيرة & 1.28 & 3.64 & تلى أساس ونق معايير التصميم المطنيم التصورة المتفق القائمة & $\wedge$ \\
\hline 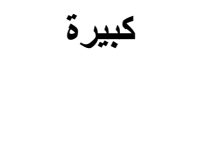 & 1.20 & 3.72 & الساعد الطلاب على استخدام استراتيجيات التفسيرات وتصريسية & 9 \\
\hline كبيرة & 1.04 & 3.52 & الطلاب على بنىاء التفسير لموات وتصميم التحلية تساعد & ! \\
\hline كبيرة & 1.11 & 3.36 & 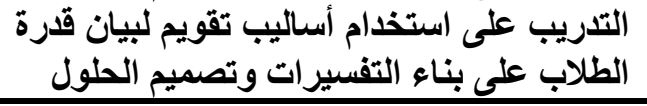 & $\vdots$ \\
\hline متوسطة & $\cdot \wedge \varepsilon$ & r.ro & المجموع الكلي & \\
\hline
\end{tabular}


برنامج مقترح قائم على معايير العلوم للجيل القادم (NGSS) لتدريب معلمي العلوم بالمرحلة الإعدادية

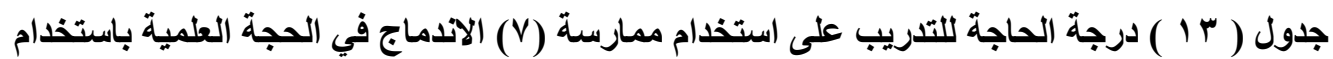

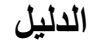

\begin{tabular}{|c|c|c|c|c|}
\hline درجة الحاجة & $\varepsilon$ & 5 & الحاجات الترريبية & s \\
\hline متوسطة & 1.10 & 3.28 & الادعاءات حجة علمية مبيناً كيف تدعم البيانات & 1 \\
\hline 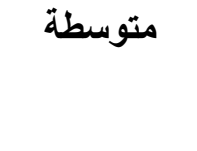 & 1.02 & 3.28 & 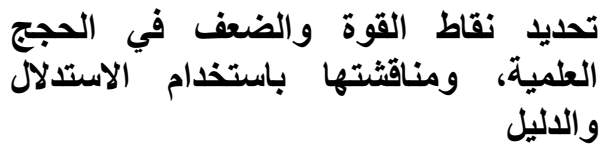 & r \\
\hline 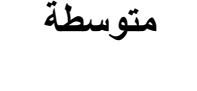 & 1.00 & 3.00 & تدريب الطلاب على تحديليا أوجها القصور في & $r$ \\
\hline متوسطة & $\cdot .91$ & 3.00 & تلديبة الطلاب على الادعاء، الدليل، التبريل مكونات الحجة & $\varepsilon$ \\
\hline متوسطة & $\cdot .95$ & 2.92 & تظرية علمية الجدل العلمي في تطوير فكرة أو & $\bullet$ \\
\hline متوسطة & 1.46 & 3.32 & 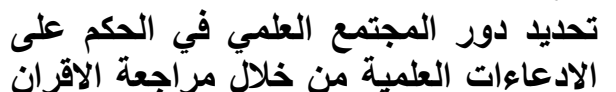 & 7 \\
\hline كبيرة & 1.47 & 3.48 & 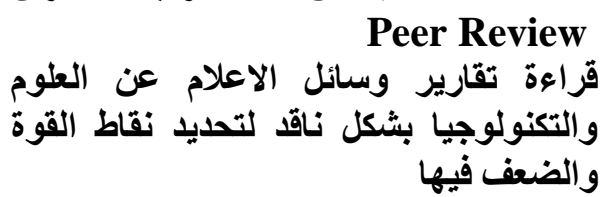 & $\checkmark$ \\
\hline كبيرة & 1.44 & 3.80 & تدريب الطلاب على تقويم حجج الآخرين & $\wedge$ \\
\hline كبيرة & 1.31 & 3.68 & صحه ادعاء على تقديم الادله الكافيه التى تدعم & 9 \\
\hline كبيرة & 1.41 & 3.40 & التـريب على تقديم الحجة المضادة & $1 \cdot$ \\
\hline 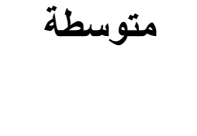 & 1.30 & 3.28 & 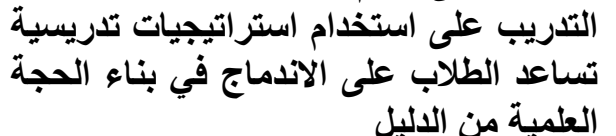 & 11 \\
\hline كبيرة & 1.47 & 3.56 & 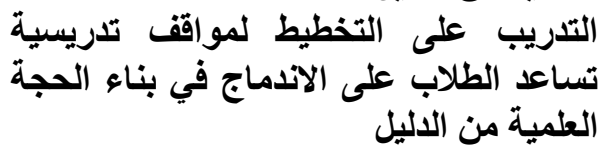 & ir \\
\hline كبيرة & 1.01 & 3.76 & قالترة الظلاب على على الاندماج أساليب تقويم لبياء الحجة & ir \\
\hline متوسطة & 1.11 & $r . \mu v$ & المجموع الكلي & \\
\hline
\end{tabular}

يتضح مـن الجدول أن متوسط الحاجة للتدريب على ممارسـة الاندماج في الحجة

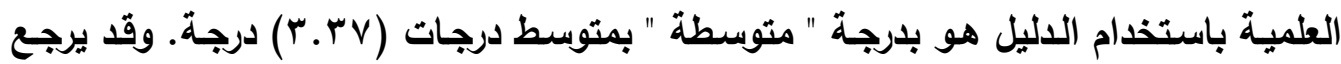

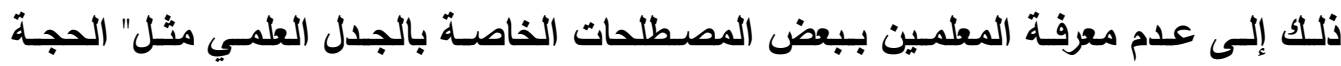
العلمية، الادعاء، الاليل، والحجة المضادة". ويالرغم من ذلك حصلت بعض الحاجات التدريبية 
على درجة " كبيرة" مثل رقم (V) قراءة تقارير وسـائل الإعلام عن العلوم والتكنولوجيا بشكل

ناقد لتحديد نقاط القوة والضعف فيها. جدول ( ؛ ا 1 ) درجة الحاجة للتدريب على استخدام ممارسة (^) الحصول على المعلومات وتقويمها

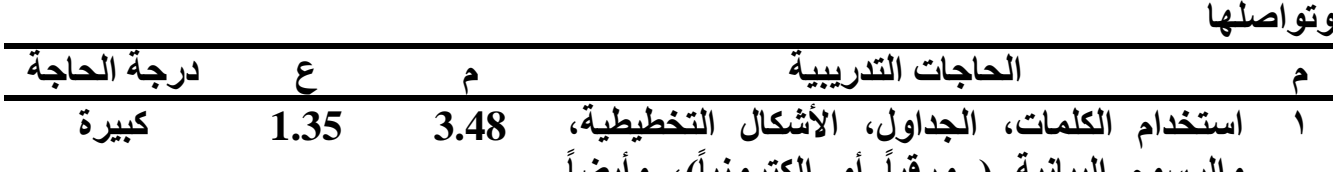

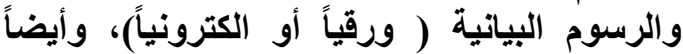

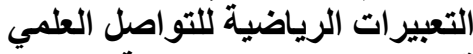

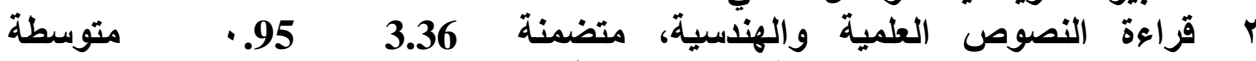
المخططات، والرسوم البيانية، وشرح البرانة الأفكار

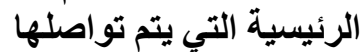

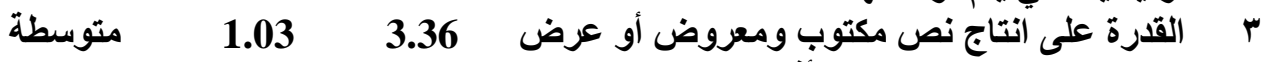

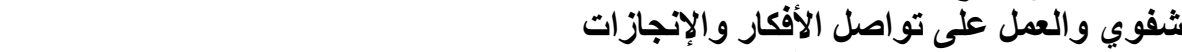
الاندماج في القراعة الناقدة للأدبيات العلمية الأولية،

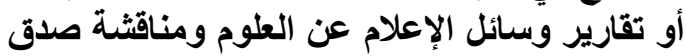

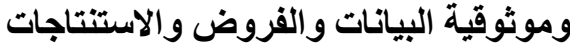

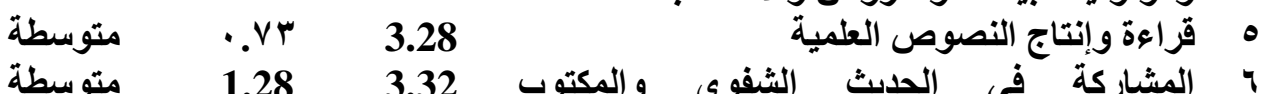

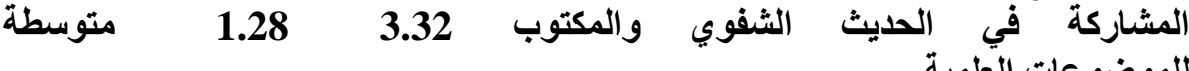
V التقويم الناقد لقيمة وصدق النصوص والحجج $\quad 3.40 \quad 3.15 \quad 3$

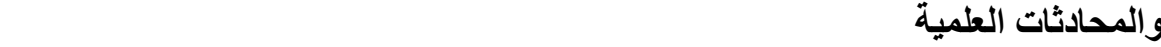
ᄉ التدريب على استخلام استراتيجيات تدريسية تساعد

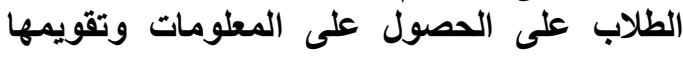

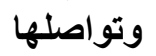
التدريب على التخطيط لمواقف تدريسية تساعد $3.52 \quad 3.04 \quad 3$.

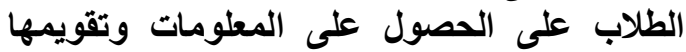

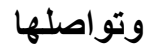
الت التريب على استخدام أساليب تقويم لبيان قدرة $\quad 3.60 \quad 3.11 \quad 30$

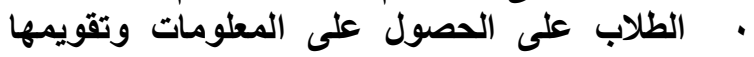

وتواصلها

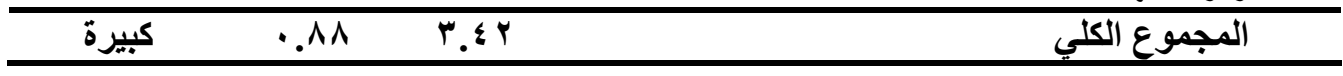

يتضح من الجدول أن الحاجة للتدريب على الحصول على المعلومات وتقويمها وتواصلها هي

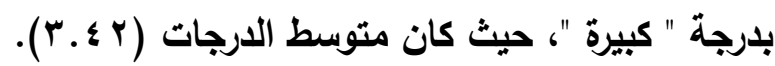

ونستخلص من خلال نتائج تطبيق استبيان الاحتياجات التدريبية لممارسات العلوم والهندسة أن ( • ) ممارسات حصلت على درجة حاجة " كبيرة "، و ( r ) ممارسات حصلت على درجة الاجل " متوسطة " كما أنه لا توجد أي ممارسة حصلت على درجة " منخفضة " . 
برنامج مقترح قائم على معايير العلوم للجيل القادم (NGSS) لتدريب معلمي العلوم بالمرحلة الإعدادية

رابعاً: إعداد البرنامج المقترح القائم على معايير العلوم للجيل القادم ( NGSS ) لتدريب معلمي العلوم بـالمرحلة الإعدادية على استخلام ممارسات العلوم والهندسة ( SEPS ) أثناء تلدريس العلوم: للإجابة على السؤال الرابع من أسئلة البحث والذي ينص على: ما التصور المقترح للبرنامسج لتدريب معلمي العلوم بالمرحلة الإعدادية على استخدام ممارسات العلوم والهندسة (SEPs) بمعايير (NGSS) أثناء تدريس العلوم ؟ تم ذلك من خلال الاستعانة بما تم التوصل إليه البحث من نتائج تتعلق بالتقرير الذاتي لمعلمي العلوم عن درجة استخدامهم لممارسات العلوم والهندسة وكذا تطبيق طلابهم لها، بالإضافة إلى ما تم التوصل إليه في قائمة الاحتياجات التدريبية لممارسات العلوم واللهندة. وفيما يلي عرضاً لمبررات وأسس ومكونات البرنامج التدريبي بشئ من التفصيل: " مبررات بناء البرنامج التدريبي: ا. ما تم التوصل إليه من نتائج أوضحت أن مستوى استخدام معلمي العلوم لممارسات العلوم والهندسة هو بلرجة "متوسطة" وهي درجة غير كافية للوصول بالطلاب إلى الى المنافسة العالمية في اختبارات العلوم الدولية. r. ما تم التوصل إليه من نتائج أوضحت أن مستوى تطبيق الطلاب لممارسات العلوم والهندسة هو بلرجة "منخفضة" وهي درجة غير مناسبة للوصول بهم إلى الدرجات

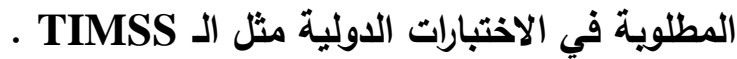
r. وجود العديد من الاحتياجات التدريبية التي حلدها معلمو العلوم من خلال تطبيق استبيان الاحتياجات التدريبية لممارسات العلوم والهندسة، ومنها خمس ممارسات بلرجة كبيرة وثثلاثة ممارسات بدرجة متوسطة.

• أسس بناء البرنامج التدريبي في ممارسات العلوم والهندسة بمعايير العلوم للجيل القادم: من خلال دراسة البحوث والدراسات التي تناولت معايير العلوم للجيل القادم وممارسات العلوم والهندسة بها مثل: دراسات (Kawasaki, 2015; Malkawy and Rababah, 2018) والمشروعات العالمية مثل: إطار التربية العلمية الذي أعده المجلس القومي للبحث عام

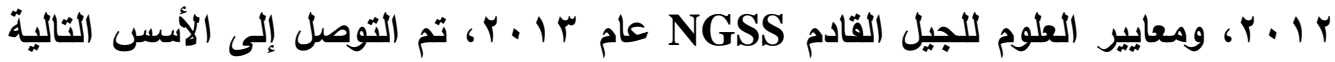
لبناء البرنامج المقترح لتنمية قدرة معلمي العلوم على استخدام ممارسات العلوم والهندسة

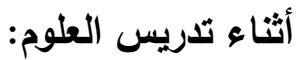


برنامج مقترح قائم على معايير العلوم للجيل القادم (NGSS) لتدريب معلمي العلوم بالمرحلة الإعدادية

1. التأكيد على تكامل ممارسات العلوم والهندسة مع المحتوى العلمي، وأيضاً تكامل الممارسات مع بعضها البعض والتأكيد على توقعات الأداء

\section{.Expectations [PEs]}

r. التأكيد على الفهم العميق لأهداف ممارسات العلوم والهندسة بمعايير العلوم للجيل القادم. r. التأكيا على دور تحدث الطلاب وتفاعلهم الاجتماعي كمصدر أساسي لتدعيم تطبيق لهمئ ممارسات العلوم واللهندة بفصول العلوم. ؛. التأكيا على تحويل مسؤولية التعلم نحو الطالب لتحقيق تطبيق ممارسات العلوم والهناسة بالقصل الاراسي. ه. مساعدة المعلمين على تعديل دروسهم الحالية لتكون مفتوحة النهاية من خلال استخدام استراتيجيات تدريسية تدعم استخدام ممارسات العلوم والهندسة. 7 ا. التأكيد على أساليب التقويم التي تساعد على تقويم استخدام ممارسات العلوم والهندسة أثناء حصص العلوم، مع ضرورة تقديم التغذية الراجعة لاروس المعلمين في الوقت المناسب لتنقيح أنشطتهم التدريسية التي تساعد على استخدام هذه الممارسات.

\section{تحديل مكونات البرنامج التلدريبي في ممارسات العلوم والاهندسة:}

( 1 ) تحليد الهدف العام من البرنامج التلدريبي: يهذف البرنامج إلى تلريب معلمي العلوم بالمرحلة الإعدادية على استخدام ممارسات العلوم والهندسة (SEPs) بمعايير العلوم للجيل القادم (NGSS) أثناء تدريس العلوم وأيضاً مساعدة طلابهم على تطبيقها أثناء حصص

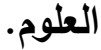
( الأهداف الخاصة للبرنامج التدريبي: بنهاية البرنامج التدريبي يتوقع أن يكون المتدرب قادراً على أن: 1. يحدد مكونات معايير العلوم للجيل القادم (NGSS) ـ

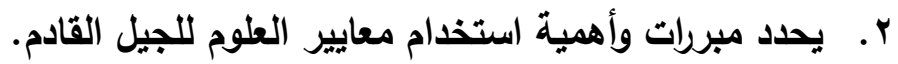
r. يحدد مفهوم ممارسات العلوم واللهنسة (SEPs) بمعاييز العلوم للجيل القادم. ع. يحدد أهمية استخدام ممارسات العلوم والهندة (SEPs) بمعايير العلوم للجيل القادم. ه. يستخدم ممارسة طرح الأسئلة وتحديد المشكلة أثناء تدريس العلوم. צ. يستخدم ممارسة تطوير واستخدام النماذج أثناء تدريس العلوم. 
برنامج مقترح قائم على معايير العلوم للجيل القادم (NGSS) لتدريب معلمي العلوم بالمرحلة الإعدادية

V. يستخدم ممارسة تخطيط وتنفيذ التحقيقات العلمية أثناء تدريس العلوم.

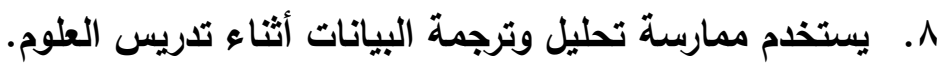
9 . . يستخدم الرياضيات والتفكير الحوسبي أثناء تدريس العلوم. ـ 1 ـ يستخدم ممارسة بناء التفبيرات وتصميم الحلول أثناء تدريس العلوم. 11 إيستخدم ممارسة الاندماج في الحجة العلمية باستخدام الدليل أثناء تدريس العلوم. r ا ـ يستخدم ممارسة الحصول على المعلومات وتقويمها وتواصلها أثناء تلريس العلوم. r ا ـ يخطط الدروس وفقاً لاستراتيجيات تدريسية تدعم استخدام ممارسات العلوم والهندسة. ـ ا.ينفذ دروس العلوم وفقاً لاستراتيجيات تدريسية تدعم استخدام ممارسات العلوم واللهندسة.

ه ا. يقوم دروس العلوم وفقاً لأساليب تقويم تلدم تقويم استخدام ممارسات العلوم واللهندة.

( ) ت r ) تحليد عنوان البرنامج التدريبي: تحدد عنوان البرنامج التدريبي في:" تدريب معلمي العلوم على استخدام ممارسات العلوم والهندسة (SEPs) بمعايير العلوم للجيل القادم " (NGSS)

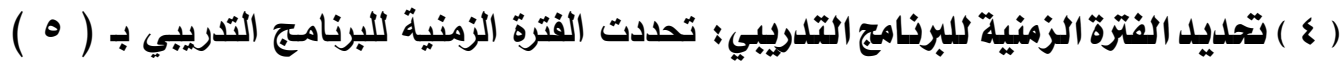
أيام تدريبية بواقع (†) ساعات يومياً، ويمجموع ( • (†) ساعة تدريبية. وتم تحديد هذه الفترة في

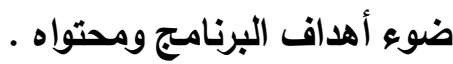
( 0 ) تحليد ملدرب البرنامج التدريبي: يمكن أن يقوم الباحث بتثفيذ البرنامج التدريبي، كما

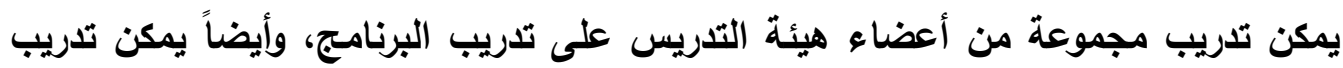
مجموعة من المعلمين المتميزين لكي يقوموا بالتدريب بعد ذلك. ويصفة عامة يجب أن تتوافر لتربل

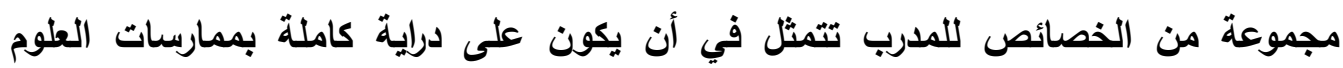

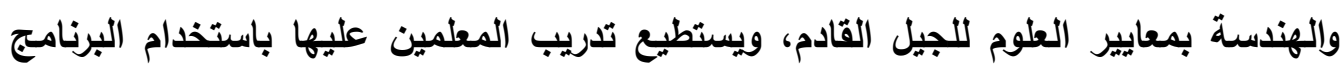
التدريبي. ( 1 ) تحليد محتوى البرنامج التدريبي: تم تحديد محتوى البرنامج التدريبي في ضوء أهدافه من خلال الاستعانة بالمشروعات العالمية، وذلك بتحديد مكونات كل وحدة تدريبية، بحيث تثمل على الأهداف والمحتوى العلمي وأوراق العمل التدريبية ووسائل التقويم، وقد اشتمل ولثل 
برنامج مقترح قائم على معايير العلوم للجيل القادم (NGSS) لتدريب معلمي العلوم بالمرحلة الإعدادية.

محتوى البرنامج التدريبي على: معايير العلوم للجيل القادم، وممارسات العلوم والهندسة الثمانية، واستراتيجيات التذريس لممارسات العلوم والهندسة، وفي النهاية يتم تقديم التغذية الراجعة للمتدربين من خلال عروض المعلمين لاروس مخططة قائمة على استخدام ممارسات العلوم والهندسة وذلك أمام زملائهم من المتدريين الآخرين. ( ) خطة البرنامج التدريبي: يوضح جدول (0 1 ) خطة البرنامج التدريبي متضمنة الأيام، والوحدات التدريبية، والجلسات، والزمن المخصص لكل جلسة، ومحتوى كل جلسة من

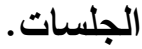

جدول(0 1 ) خطة البرنامج التدريبي في ممارسات العلوم والهندة (SEPs) بمعايير (NGSS)

\begin{tabular}{|c|c|c|c|c|}
\hline محتوى الجلسة & الزمن & الجلسة & الوحدة التدريبية & اليوم \\
\hline - - مفهوم ونشـأة وأهمية معايير العلوم للجيل & $د 1 \wedge$. & الأولى & $\begin{array}{r}\text { معايير العلوم للجيل القـادم } \\
\text { (NGSS) }\end{array}$ & \multirow[t]{2}{*}{ الأول } \\
\hline - - مفهوم ممارسات العلوم و الهندسة وأهميتها & $د 1 \Lambda$. & الثانية & $\begin{array}{l}\text { ممارسات العلوم والهندسـة } \\
\text { (SEPS) }\end{array}$ & \\
\hline - ممارسة طرح الأسئلة وتحديد المشكلات & $د$. & الثالثة & 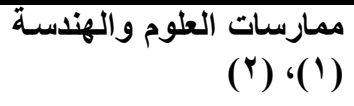 & \multirow[t]{2}{*}{ الثاني } \\
\hline - - ممارسة تخطيط وتنفيذ التحقيقات العلمية & $د 1 \Lambda$. & الرابعة & 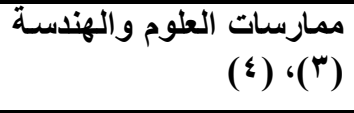 & \\
\hline 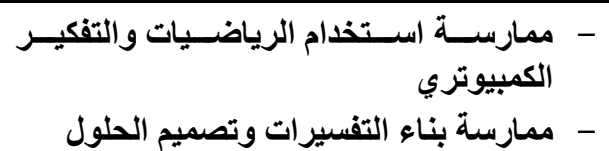 & $د 1 \wedge$. & الخامسة & 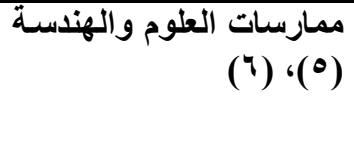 & \multirow[t]{2}{*}{ الثالث } \\
\hline 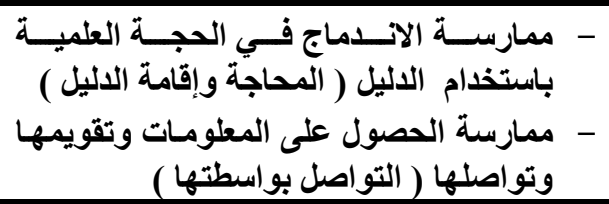 & $د$ A . & السادسة & 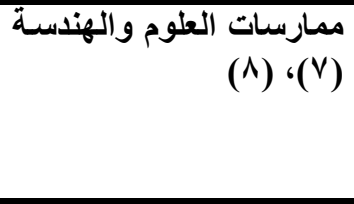 & \\
\hline 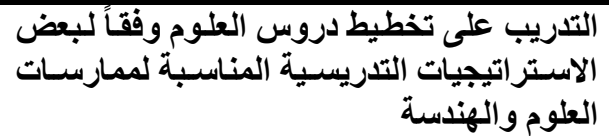 & $د 1 \wedge$. & السابعة & 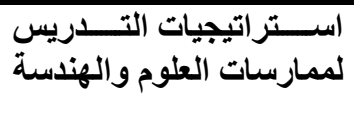 & \multirow[t]{2}{*}{ الرابع } \\
\hline 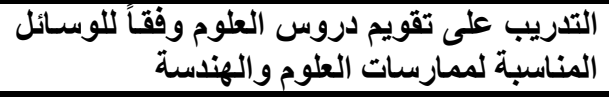 & $د 1 \wedge$. & الثامنة & 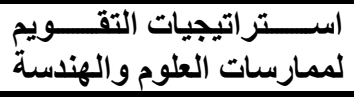 & \\
\hline 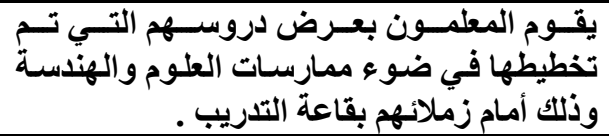 & $د 1 \wedge$. & التاسعةة & عروض المعلمين (1) & \multirow[t]{2}{*}{ الخامس } \\
\hline 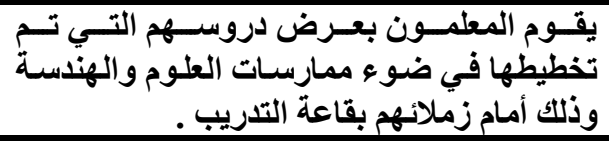 & $د 1 \wedge$. & العاشرة & عروض المعلمين (Y) & \\
\hline
\end{tabular}


) ( ) طريقة تنفيذ البرنامج المقترح: يعتمد البرنامج التدريبي بشكل أساسي على الحوار والمناقشة بين المعلمين بعضهم البعض من خلال مجموعات العمل، ويينهم وبين المدرب من بن ناحية أخرى وأيضاً جلسات العصف الذهني المختلفة مع عرض الخبرات التدريسية الذاتية. ولا يقتصر تنفيذ البرنامج التدريبي على قاعات التدريب فقط بل أنه توجد مجموعة من الآليات التي يمكن استخدامها في تنفيذ البرنامج ومنها: عقد اللقاءات الفردية والجماعية مع المعلمين بهاف توضيح أهمية استخدام ممارسات العلوم والهندسة (SEPs) بمعايير العلوم للجيل القادم (NGSS) ـ أيضاً تدريب المعلمين على كيفية استخدام كل ممارسة من الممارسات الثمانية. بالإضافة القيام بالزيارات الميدانية للمعلمين المتدربين بهدف تقييم مدى

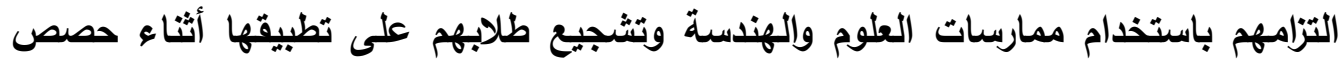
العلوم، مـع الاطلاع على خططهم التدريسية بدفاتر التحضير وعمل تغذية راجعة مناسبة.

( 9 ( تقويم البرنامج التدريبيه : يمكن استخدام مجموعة من الأساليب التالية لتقويم البرنامج التدريبي: 1. استخدام الملاحظات بالفصل الدراسي وتقديم التغذية الراجعة المناسبة بشكل فردي أو الاسبالئ جماعي أو من خلال التواصل الإلكتروني. وأيضاً إجراء المقابلات الشخصية مع الثعه المعلمين.

r. التقويم القبلي ويتضمن معرفة المعلومات القبلية للمعلمين بممارسات العلوم والهندسة (يمكن استخدام الاختبار في ملحق 1 ) والذي استخدم في الدراسة الاستطلاعية للبحث.

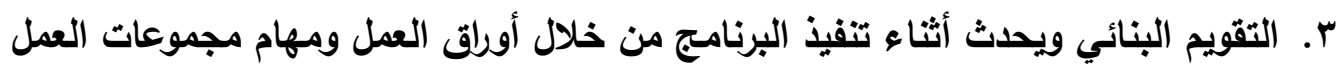
التعاوني والتحقق من مدى مشاركة المعلمين وفاعليتهم أثناء التدريب. ء. التقويم الختامي ويتم من خلال تطبيق الاختبارات والاستبيانات المرتبطة بممارسات العلوم والهندسة، وأيضاً من خلال عروض المعلمين وتخطيطهم للاروس وفقاً لهذه الممارسات. ه. تقويم البرنامج التدريبي باستخدام استمارة التتقيم والتي تتضمن تقييم المدرب وتقييم المادة العلمية للبرنامج التدريبي والتقييم الأتي للمتدرب ( مرفق في نهاية البرنامج

$$
\text { (التدريبي ) }
$$




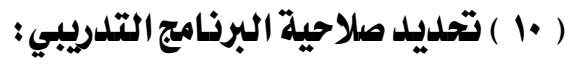

للتأكد من صلاحية البرنامج التدريبي المقترح القائم على ممارسات العلوم وإلهندة للتطبيق على معلمي العلوم، قام الباحث بعرضه على مجموعة من الخبراء في التربية العلمية، وكذا مجموعة من معلمي العلوم بالمرحلة الإعدادية وتم إجراء التعديلات المطلوية.

\section{مناقشة نتمائج البحث}

أظهرت نتائج البحث أن معلمي العلوم بالمرحلة الإعدادية يستخدمون ممارسات العلوم والهندسة (SEPs) بلرجة " متوسطة" أثناء تدريس العلوم. ويعتبر هذا فى حد ذاته شيء مشجع ومقلق في نفس الوقت. فإذا كانت هناك رغبة لتحسين الدرجات الخاصة بالاختبارات الاولية لتواكب الارجات على مستوى العالم يجب أن يكون استخدام ممارسات (SEPs) من قبل معلمي العلوم أعلى من ذلك بكثير. كما أوضحت النتائج أن كل الـ (SEPs) استخدمت لـان مرات قليلة فى الثهر، ولكن بشكل مثالي يجب أو من الأفضل أن تكون كل يوم تقريباً. كما

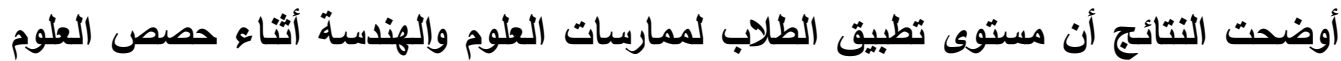
بارجة " منخفضة " وهو شىع مقلق ويفسر الارجات المنخفضة والترتيب المتأخر في نتائج الاختبارات الدولية. وقد أوضحت النتائج أيضاً وجود حاجة ملحة للتدريب على ممارسات العلوم والهندسة وذلك من خلال نتائج تطبيق استبيان الاحتياجات التدريبية على معلمي العلوم. وفيما يلي مناقشة تفصيلية لنتائج البحث.

أولاً : مناقشة نتائج تطبيق استبييان ممارسات العلوم وا اهندسة (SEPS) على معلمي العلوم : أوضحت نتائج البحث أن مستوى استخدام معلمي العلوم لممارسات العلوم والهندسة

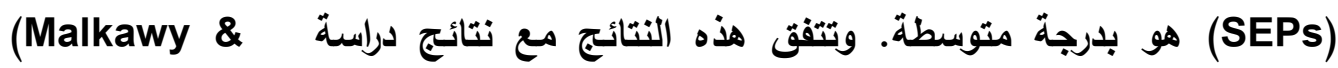
Rababah, 2018) بالأردن لممارسات العلوم والهندة هو بلرجة متوسطة. وقد أظهرت النتائج وجود ثلاث ممارسات برجة منخفضة من حيث استخدامها من قبل معلمى العلوم، وهي ممارسة ( 1 ( )

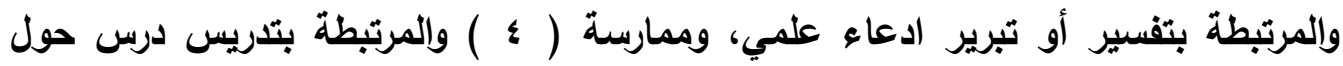
كيفية كتابة النتائج العلمية في تقرير مختبر أو مقالة علمية، وممارسة ( 1 ( ) والمرتبطة بتدريس درس عن ترجمة الإحصاءات أو البيانات الكمية. وهذا يشير إلى ضرورة البحث عن فئه آليات لتدعيم هذه الممارسات لاى معلمي العلوم. كما أنه من الضروري إعادة النظر في لبري 
برامج إعداد معلم العلوم حيث إن معاييز العلوم للجيل القادم بما تتضمنه لممارسات العلوم والهندسة هي معايير جديدة يجب تضمينها ببرامج إعداد المعلم وأيضاً برامج تدريبه بوزارة التربية والتعليم. ويمكن القول أنه يوجد شىع مقلق وهو إعداد معلم العلوم وعلاقته بالاستخدام الفعال لا SEPs فى الفصل الدراسي. ويمكن أن يشير ذلك إلى نقص فاعلية

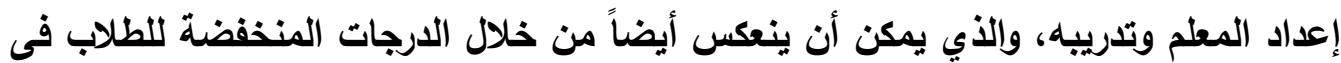
الاختبارات الاولية.

ويمكن تقديم المزيد من التفسيرات لهذه النتائج من خلال الملاحظات التي خرج بها الباحث أثناء التطبيق للاستبيانات على معلمي العلوم والتي أظهرت ما يلي: 1. عدم اقتتاع بعض معلمي العلوم بأهمية بعض ممارسات العلوم والهندسة مثل تدريس درس عن ترجمة الإحصاءات أو البيانات الكمية وهو الأمر الذي يفسر انخفاض متوسط درجات هذه الممارسة لاى المعلمين مجموعة البحث. r. قصور استخدام ممارسات مثل الجدل العلمي ويناء العجة العلمية وظهر هذا من خلال انخفاض استخدام هذه الممارسة أثناء التدريس، وأيضاً قصور استخدام ممارسة " كتابة التقارير العلمية والنتائج العلمية في تقرير مختبر أو مقالة علمية. ويعتبر ذلك عائق لتنفيذ الإصـلاح، حيث إن أهداف ومعتقدات وفهم المعلمين عن الإصـلاح فـى التربيـة العلميـة تـؤثر على الطـرق التـي يتحقى بهـا الهــف مـن الإصـلاح (Kawasaki, 2015). ومن ثم وجب تقديم البرامج التدريبية التي تعمل على تصحيح الفهم والأهداف للمعلمين ويصفة خاصـة فيمـا يتعلق بممارسـات العلوم والهندسـة بمعـايير العلوم للجيل القادم. حيث إنه لكي يكون المعلم قادر على استخدام ممارسات (SEPs) ، فإنه يجب أن يتـدرب أولاً على كيفيـة استخدامها بشـكل فعـال. وينـاء على ذلـك فإنـها يقـع على عـاتق المسؤولين عن إعداد المعلم مسئوولية التأكد من أن المعلمين معدين بشكل مناسب للتدريس فى الفصل باستخدام هذا الجاتب.

ثانياً :مناقشة نتائج استبيان ملدى تطبيق ممارسات العلوم والهندسة ( SEPS ) من قبل الطلاب : أوضحت نتائج البحث أن المستوى العام لتطبيق الطلاب بالمرحلة الإعدادية لممارسات العلوم والهندسة (SEPs) هي بدرجة " منخفضة "، وهذا يمثل شيء ( مقلق ) ويفسر الدرجات المنخفضة للطلاب في الاختبارات الدولية، والتي تتطلب أن يقوم الطلاب 
برنامج مقترح قائم على معايير العلوم للجيل القادم (NGSS) لتدريب معلمي العلوم بالمرحلة الإعدادية

بتطبيق ممارسات (SEPs) بشكل مكثف وفعال أثناء حصص العلوم. ويمكن القول أن هذه النتيجة هي انعكاس لاستخدام معلمي العلوم لممارسات العلوم والهندسة بدرجة متوسطة. وهذا ما أكلات عليه دراسة (2015) من ميث ضرورة فهم معلم العلوم واستخذامه لممارسات (SEPs) وعلاقته بتفيذ الدروس بالفصل وإنعكاس ذلك على تطبيق الطلاب لها.

ثالثاً : مناقشة نتائج تطبيق استبيان تحليد الاحتياجات التدريبية في ممارسات العلوم والهندسة (SEPs) أوضحت نتائج تطبيق استبيان تحديد الاحتياجات التدريبية وجود ( 0 ) ممارسات من

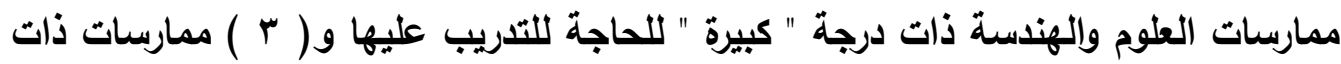
حاجة " متوسطة " . ويفسر الباحث الحاجة المتوسطة للتدريب على الثلاث ممارسات بأن المعلمين غير مدركين المقصود بهذه الممارسات ومصطلحاتها مثل الحجج العلمية، الادعاء،

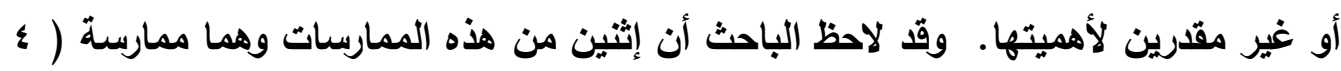
) والمرتبطة بتحليل وترجمة البيانات، وممارسة ( 1 ( ) والمرتبطة بيناء التفسيرات وتصميم الحلول حصلت على درجة " متوسطة " في قائمة الاحتياجات التدريبية، وفي نفس الوقت حصلت على درجة " منخفضة" من حيث استخدام المعلم لها. وفي هذا الصدد اشارت دراسة Almomani (2016)

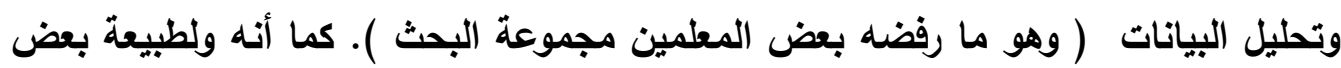
الممارسات لا يمكن استخدامها عادة كممارسة قائمة بذاتها. فعلى سبيل المثال، فإن ممارسية

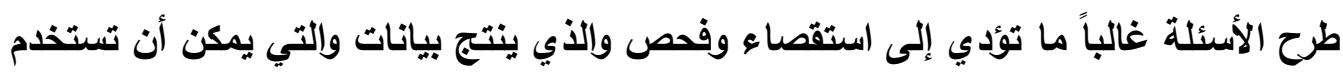
كدليل لتطوير تفسيرات أو حجج. بطريقة مماثلة، فالرياضيات متضمنة فى جميع العلوم

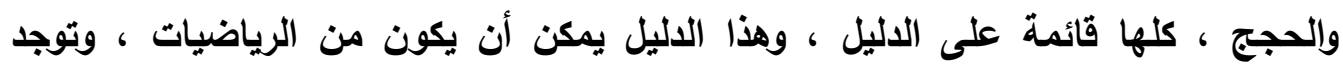

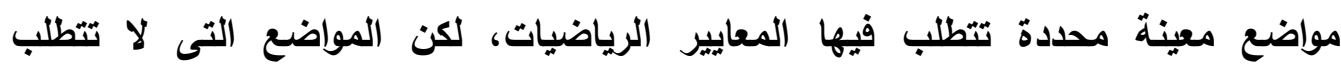
الرياضيات بشكل صريح لا ينبغي أن تفسر على أنها تمنع الطلاب من استخدام العلاقات الرياضية لدعم الممارسات الأخرى.

وقد أشار بعض المعلمين أثناء تطبيق الاستبيان عليهم بأن:

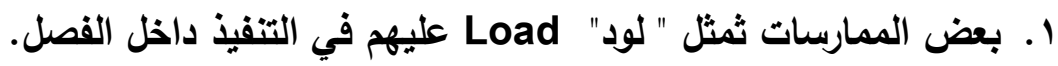


برنامج مقترح قائم على معايير العلوم للجيل القادم (NGSS) لتدريب معلمي العلوم بالمرحلة الإعدادية.

r. المنهج الحالي يتسم بعدم المرونة كما أن محتواه لا يتناسب مع تنفيذ واستخدام ممارسات العلوم واللهندسة.

r. المعلم غير جاهز للتدريب على هذه الممارسات نظراً لضيق الوقت. ـ. الطالب غير قادر على استيعاب وتطبيق ممارسات العلوم والهندسة بسبب ضيق الوقت. وفي هذا الصدد يرى المجلس القومي للبحوث (NRC) أن على معلمي العلوم

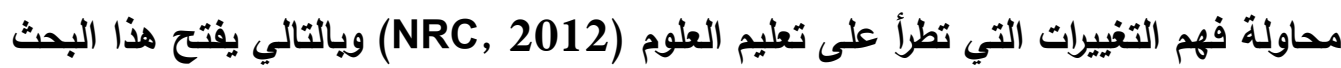

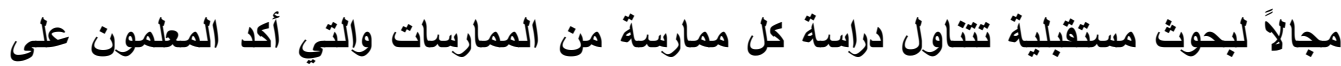
حاجتهم للتدريب عليها، والتي لم يحبذ المعلمون التدريب عليها أيضاً. وأوضحت النتائج أيضاً حصول البنود الخاصة بالتدريب على " استخدام استراتيجيات تدريسية لتدعيم استخدام ممارسات العلوم والهندسة " على أعلى الارجات ما بين " بدرجة

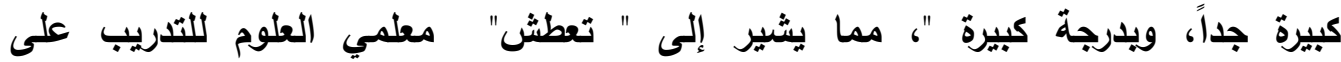
الاستراتيجيات التدريسية الحديثة والمبتكرة التي تساعدهم في عملهم أثناء فصول العلوم ويصفة خاصة التي تدعم استخدام وتطبيق ممارسات العلوم والتهنسة لدى طلابهم.

\section{التضمينات التربورية للبحث}

قدم البحث برنامجـاً تـديبياً لمعلمسي العلـوم لتفعيل استخدام ممارسـات العلـوم والهندسـة (SEPs) بمعايير العلوم للجيل القادم (NGSS) ، ويمكن تطبيق البرنـامج والاستفادة مـن النتائج في تطوير البرامج التدريبية لمعلمي العلوم. ونتائج البحث تقدم بيانـات مهمـة ريمـا

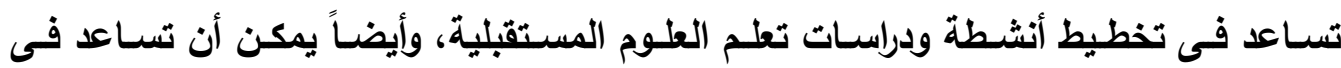

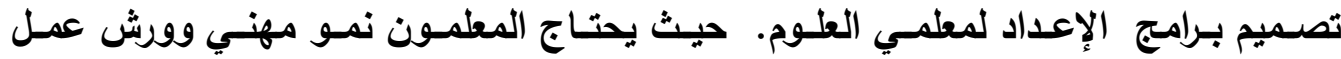

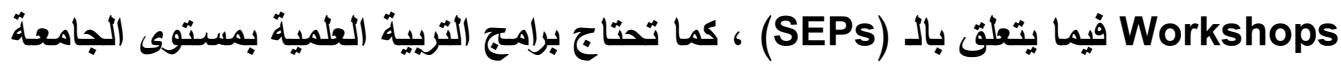
إلى التركيز على استخدام الـ (SEPs) فى الفصول الدراسية. ويجب أن يركز مؤلفو المناهج على تزويــ الطـلاب بخبـرات الـتعلم المسـتمر مـــى الحيـاة المرتبطـة باحتياجـاتهم الحاليـة

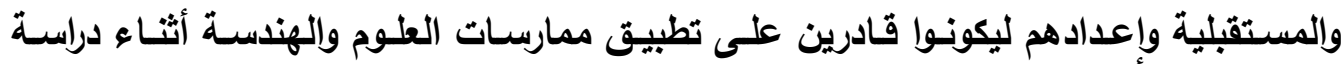

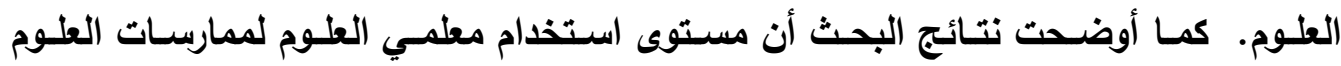

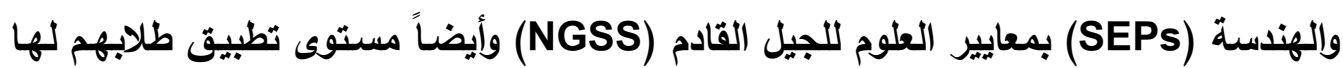
أثناء حصص العلوم لا يواكب المستوى المطلوب للمنافسة العالمية. ومـن ثم يجب أن يتم 
برنامج مقترح قائم على معايير العلوم للجيل القادم (NGSS) لتدريب معلمي العلوم بالمرحلة الإعدادية

تطوير برامج إعداد المعلم والبرامج التدريبية بحيث تسـهم في الارتقاء بمستوى معلم العلوم - الحالي والمستقبلي

استخدم البحث الحسالي التقرير الذاتي، ويالتالي فالبحوث المستقبلية يمكن أن تسـخدم الملاحظـة لقيـاس ممارســات (SEPs) فـى الفصـل الـواقعي مـن خـلال الملاحظـة المباشـرة

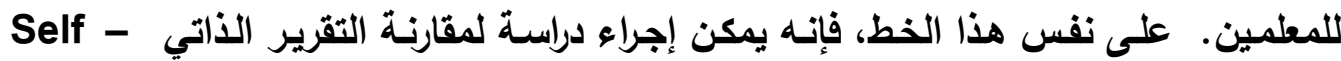
Reported للاستخدام في الفصل مـع الاستخدام الملاحظ من قبل الباحث بـاخل الفصل، والنتائج يمكن أن تؤكد موثوقية بيانات التقرير الذاتي فى هذا البحث. وأخيراً، من المأمول أن يمهـ هذا البحث الطريق للمزيد من الأبحاث على استخدام ممارسـات (SEPs) في تدريس العلوم بجمهورية مصر العربية، وسوف يكون نقطة بداية لكيفية زيادة استخدامها لتحسين أداء الطلاب فى التربية العلمية حتى الوصول إلى المنافسة العالمية المطلويـة. حيث يمثل هذا البحث دراسـة استكثـافية Exploratory Study نظراً لاسـتخدام مجموعـة بسيطة مـن معلمسي العلـوم لاراسـة مـدى اسـتخدامهم لممارسـات العلـوم والهندسة بفصولهم الدراسية، لكن يمكن التوسع في تعميم نتائج البحث نظراً لتجانس مجتمع مهي البحث وهـم معلمـي العلوم الذين يدرسـون منـاهج العلوم بالمرحلـة الإعداديـة، كمـا يمكن أن

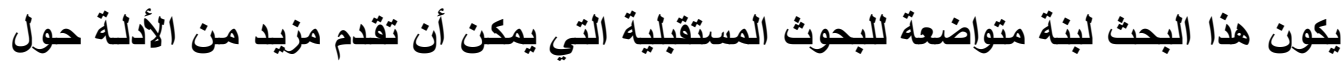
مدى استخدام معلمي العلوم لممارسـات العلوم والهندسـة بمعايير العلوم للجيل القادم وذلك فئك بهدف تطوير هذا الاستخدام بمـا ينعكس على نتائج الطلاب في المنافسـات العالميـة في العلوم.

\section{توصيات البحث ومقترحات بلدراسات مستقبلية}

أولاً: توصيات البحث:

في ضوء ما توصل إليه البحث من نتائج يوصى بما يلي: 1. تطبيق البرنامج التدريبي المقترح على معلمي العلوم بالمرحلة الإعدادية وإدراجه ضمن البرامج التدريبية بوزارة التربية والتعليم. r. تصميم برامج تدريبية مماثلة لمعلمي العلوم بالمرحلة الثانوية لتدعيم استخدامهم لممارسات العلوم والهندسة داخل الفصل الاراسي. 
برنامج مقترح قائم على معايير العلوم للجيل القادم (NGSS) لتدريب معلمي العلوم بالمرحلة الإعدادية

r. ضرورة إعادة النظر في برامج إعداد معلمي العلوم وتطويرها لتواكب ممارسات العلوم والهندسة بمعايير العلوم للجيل القادم.

؛. الاهتمام بتطبيق الطلاب لممارسات العلوم والهندسة في جميع المراحل الدراسية، والعمل على تضمينها بمناهج العلوم بجميع الصفوف التعليمية. ه. الاستفادة من أدوات البحث الحالي والمتمثلة في استبيان تحديد مدى ممارسة معلمي العلوم لممارسات العلوم واللهندة وأيضاً مدى تطبيق طلابهم لها، كما يمكن الاستفادة من قائمة الاحتياجات التدريبية والبرنامج التدريبي المقترح في البحوث والدراسات المستقبلية.

\section{ثانياً : مقترحات ببحوث مستقبلية :}

I. تطوير برامج تلريب معلمي العلوم في ضوء ممارسات العلوم والهندسة .

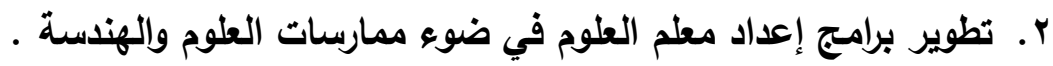
r. تطوير مناهج العلوم بمراحل التعليم العام ( البيولوجيا - الكيمياء - الفيزياء - علوم الأرض والفضاء ) في ضوء ممارسات العلوم والهندسة بمعايير العلوم للجيل القادم.

؛. . إعادة بناء وحدة مقترحة في العلوم في ضوء ممارسات العلوم والهندسة. ه. بناء برنامج أنشطة إثرائية لتنمية قدرة طلاب المرحلة الابتدائية/ الإعدادية/ الثانوية على صلى استخدام ممارسات العلوم واللهندسة. 


\section{مراجــع البحــث}

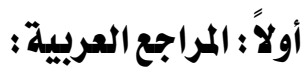

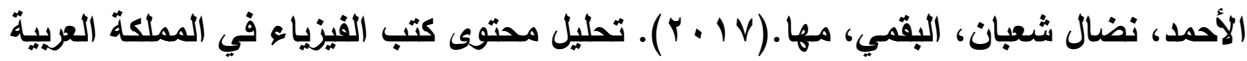
السعودية في ضوء معايير العلوم للجيل القادم (NGSS). المجلة الأردنية في العلوم

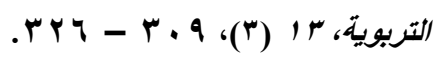

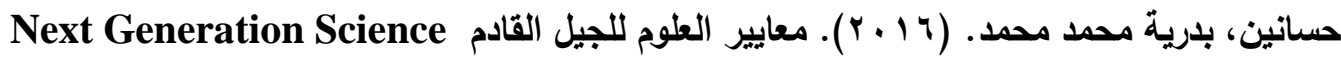
Standards

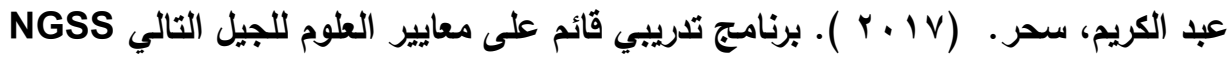

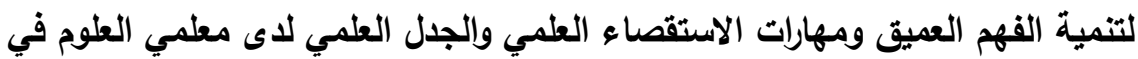

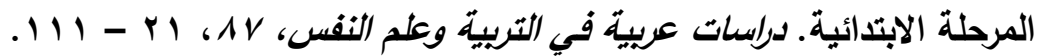

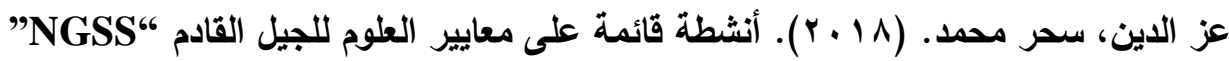

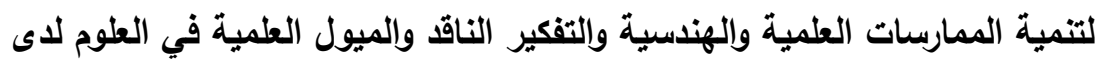

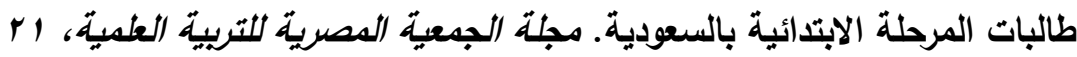

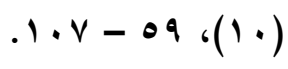

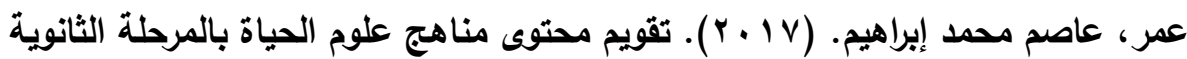
بجمهورية مصر العربية في ضوء معايير العلوم للجيل القادم (NGSS).

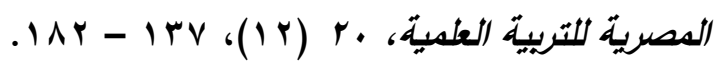

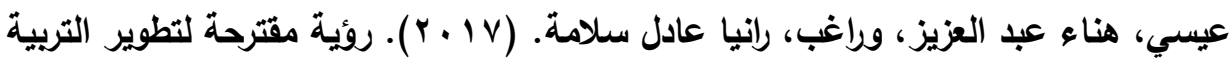

الجيولوجية عبر المراحل الاراسية المختلفة من منظور معايير العلوم للجيل القادم

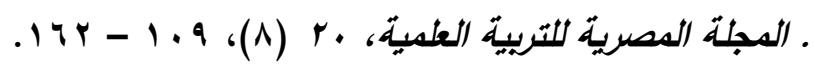

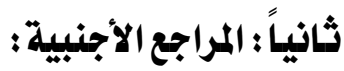

Achieve. (2012). Next generation science standards. Retrieved from http://www.nextgenerationscience.org.

Achieve. (2013). DCI arrangements of the next generation science standards. Washington, DC: Next Generation Science Standards. Retrieved from: www.nextgenescience.org.

Allen, C. D., \& Penuel, W. R. (2014). Studying teachers' sensemaking to investigate teachers' responses to professional development focused on new standards. Journal of Teacher Education, 66(2), 136-149.

Almomani, A. (2016). A suggested vision for teaching science in Jordan 
برنامج مقترح قائم على معايير العلوم للجيل القادم (NGSS) لتدريب معلمي العلوم بالمرحلة الإعدادية.

in light of (NGSS) (Unpublished doctoral dissertation). Yarmouk

University, Jordan.

Alweher, M. (2016). Inquiry and teaching science by inquiry.

Germany: Noor Publishing.

American Association for the Advancement of Science (AAAS). (1989):

Science for all Americans, Project 2061. Washington.

www.aaas.org/project206112061main.htm.

American Association for the Advancement of Science (AAAS). (1993):

Benchmarks for Science Literacy, Project 2061, Washington. www.aaas.org/project206112061main.htm

Bennett, J., \& Hogarth, S. (2009). Would you want to talk to a scientist at a party? High school students' attitudes to school science and to science. International Journal of Science Education, 31 (14), 1975-1998. doi:10.1080/09500690802425581.

Brislin, R. W. (1970). Back-translation for cross-cultural research. Journal of Cross-Cultural Psychology, 1(3), 185-216.

Bybee, R. W. (2011). Scientific and engineering practices in K-12 classrooms: Understanding 'a framework for $\mathrm{K}-12$ science education'. Science and Children, 49(4), 10-16.

Crawford, B. A., Capps, D. K., van Driel, J., Lederman, N., Lederman, J., Luft, J. A., et al. (2014). Learning to teach science as inquiry: Developing an evidence-based framework for effective teacher professional development. Topics and Trends in Current Science Education: Springer.

Duschi, R., \& Bybee, R. (2014). Planning and carrying out investigations: An entry to learning and to teacher's professional development around NGSS science and engineering practices. International Journal of STEM Education, 1, 1-12. doi:10.1186/s40594-0140012-6

Duschl, R. A., \& Grandy, R. (2013). Two views about explicitly teaching nature of science. Science \& Education, 22(9), 2109-2139.

English, L., \& King, D. (2015). STEM learning through engineering design: Fourth-grade student's investigations in aerospace. International Journal of STEM Education, 2(14), 2-18.

Furtak, E. M., Seidel, T., Iverson, H., \& Briggs, D. C. (2012). Experimental and quasiexperimental studies of inquiry-based science teaching a meta-analysis. Review of Educational Research, $82(3), 300-329$.

Gassom, N. (2013). Teaching science in the Arab world needs a large and immediate leap. Retrieved from: http://blog.icoproject.org/ 
برنامج مقترح قائم على معايير العلوم للجيل القادم (NGSS) لتدريب معلمي العلوم بالمرحلة الإعدادية.

Hattie, J. (2012). Visible learning for teachers: Maximizing impact on learning: Routledge.

Herman, J. L. (2009). Moving to the next generation of standards for science: Building on recent practices. Los Angeles: National

Center for Research on Evaluation, Standards, and Student Testing (CRESST).

Kawasaki, J. N. (2015). Examining teachers' goals and classroom instruction around the science and engineering practices in the Next Generation Science Standards (UCLA electronic theses and dissertations, Ph.D). Retrieved from:

https://escholarship.org/content/qt1pb2647r/qt1pb2647r.pdf

Khachatryan, E. (2015). Feedback on teaching from observations of teaching what do administrators say and what do teachers think about it? NASSP Bulletin, Retrieved from:

https://doi.org/10.1177\%2F0192636515583716.

Kloser, M. (2014). Identifying a core set of science teaching practices: A Delphi expert panel approach. Journal of Research in Science Teaching, 51(9), 1185-1217.

Lederman, N., \& Lederman, J. (2013). Next generation science standards teacher educators. Journal of Science Teacher Education, 24(1), 929-932.

Lee, O., Quinn, H., \& Valdes, G. (2013). Science and language for English language learners in relation to Next Generation Science Standards and with implications for Common Core State Standards for English language arts and mathematics. Educational Researcher, 42(4), 223-233, DOI: 10.3102/0013189X13480524.

Malkawi, A. \& Rababah, E. (2018). Jordanian twelfth-grade science teachers' self-reported usage of science and engineering practices in the next generation science standards, International Journal of Science Education, (40) 9, 961- 976, doi:10.1080/09500693.2018.1460695

Mansour, N. (2015). Science teachers' views and stereotypes of religion, scientists and scientific research: A call for scientist-science teacher partnerships to promote inquiry-based learning. International Journal of Science Education, 37(11), 1767-1794. doi:10.1080/09500693.2015. 1049575.

Martin, M. O., Mullis, I. V. S., Foy, P., \& Hooper, M. (2016). TIMSS 2015 international results in science. Retrieved from Boston College, TIMSS \& PIRLS International Study Center website: http://timssandpirls.bc.edu/timss2015/international-results 
برنامج مقترح قائم على معايير العلوم للجيل القادم (NGSS) لتدريب معلمي العلوم بالمرحلة الإعدادية.

McNeill, K. L., \& Knight, A. M. (2013). Teachers' pedagogical content knowledge of scientific argumentation: The impact of professional development on K-12 teachers. Science Education, 97(6), 936-972.

Moon, J., Michaels, S., \& Reiser, B. J. (2012). Science standards require a teacherlearning rethink. Retrieved from:

http://www.edweek.org/ew/articles/2012/11/30/13moon.h32.html?tkn

Morales, C. J. (2016). Adapting to national standards: The experience of one middle school science teacher's implementation of the Next Generation Science Standards (NGSS) (Unpublished doctoral dissertation). University of Michigan.

National Research Council. (1996). National Science Education Standards. Washington DC: National Academy Press.

National Research Council [NRC]. (2012). A framework for (k-12) Science education: Practices, crosscutting concepts, and core ideas. Washington, DC: National Academy of Science.

National Research Council. (2015). Next generation science standards. Retrieved from http://www.nextgenscience.org/resources

National Science Teachers Association. (2013). NSTA's report: Putting NGSS in to practice, $K-12$. Retrieved from www.nsta.org/2014stemforum

Next Generation Science Standards. (2013a). Development overview. Retrieved from: http://www.nextgenscience.org/developmentoverview

The Next Generation Science Standards (NGSS). (2016). Three dimensional learning. Retrieved from: http://www.nextgenscience.org/three-dimensions NGSS Lead States. (2013). Next generation science standards for states by states. Washington, DC: National Academy Press. Retrieved from: https://www.nap.edu/read/18290/chapter/1.

Odeh, A. (2010). Measurement and evaluation in the teaching process (5th ed.). Amman: Dar Alamel.

Osborne, J. (2014). Teaching scientific practices: Meeting the challenge of change. Journal of Science Teacher Education, 25(2), 177-196.

Pellegrino, J. W. (2013). Proficiency in science: Assessment challenges and opportunities. Science, 340(6130), 320-323.

Pruitt, S. L. (2014). The next generation science standards: The features and challenges. Journal of Science Teacher Education, 25(2), 145156.

Qablan, A. (2016). Teaching and learning about science practices: Insights and challenges in professional development. Teacher 
برنامج مقترح قائم على معايير العلوم للجيل القادم (NGSS) لتدريب معلمي العلوم بالمرحلة الإعدادية. .

Development Journal, 20(1), 76-91.

Saleh, H. (2018). A Study of the Effectiveness of the Next Generation Science Standards Implementation at a Private US Curriculum School in Dubai, UAE. Dissertation submitted in fulfilment of the requirements for the degree of Master of Education at The British University in Dubai.

Taylor, D. L., \& Booth, S. (2015). Secondary physical science teachers' conceptions of science teaching in a context of change. International Journal of Science Education, 37 (8), 1-22.

The Next Generation Science Standards (NGSS). (2016). Three dimensional learning. Retrieved from: http://www.nextgenscience.org/three-dimensions

Windschitl, M., Thompson, J., Braaten, M., \& Stroupe, D. (2012).

Proposing a core set of instructional practices and tools for teachers of science. Science Education, 96(5), 878-903.

Yoon, S. Y., Suh, J. K., \& Park, S. (2014). Korean students' perceptions of scientific practices and understanding of nature of science. International Journal of Science Education, 36(16), 2666- 2693. doi:10.1080/09500693.2014.928834. 